NATIONAL WATER-QUALITY ASSESSMENT PROGRAM SOURCE WATER-OUALITY ASSESSMENT

\title{
Anthropogenic Organic Compounds in Ground Water and Finished Water of Community Water Systems in the Northern Tampa Bay Area, Florida, 2002-04
}

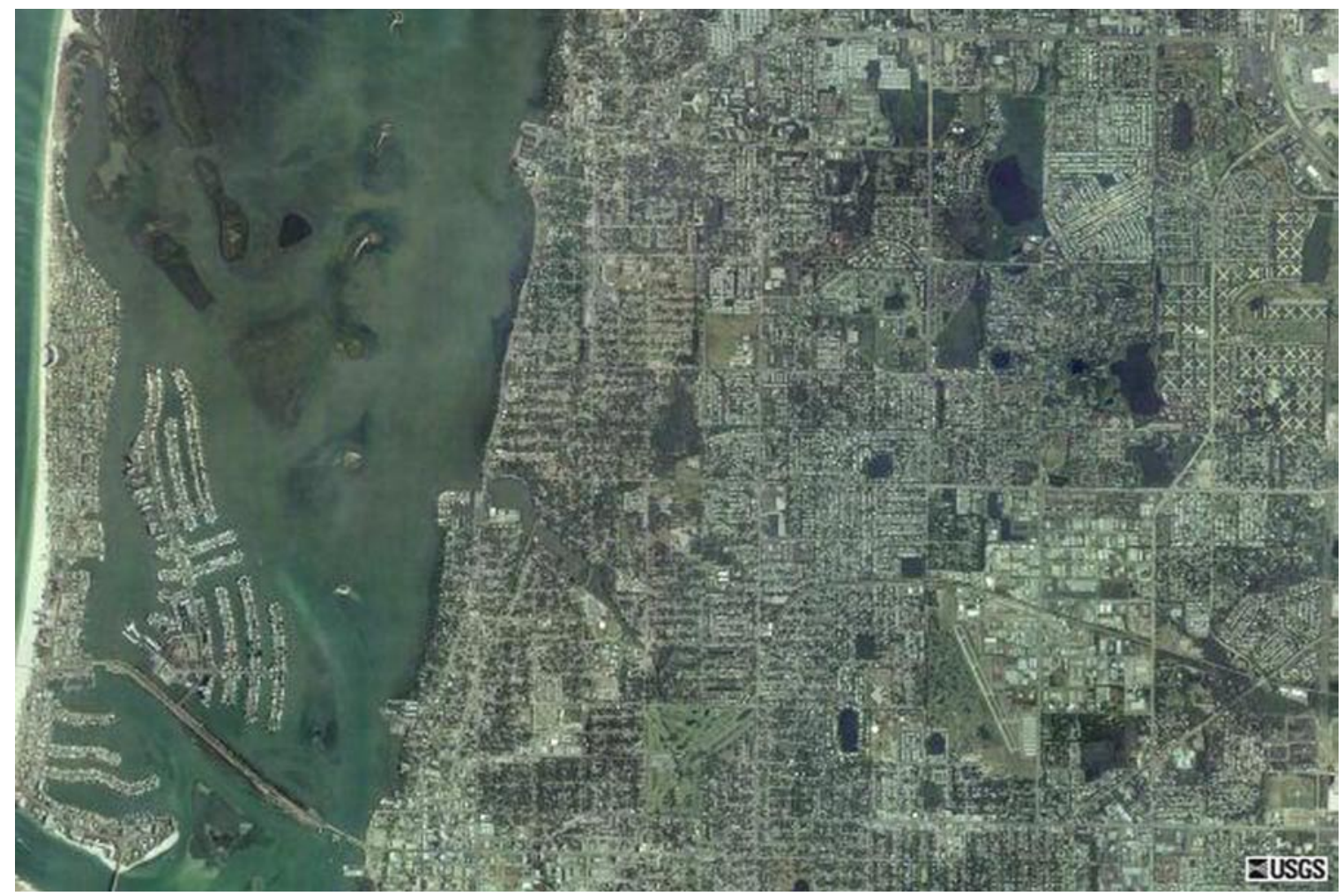

Scientific Investigations Report 2006-5267 
Cover: Aerial photograph of Clearwater, Florida, May 8, 2002 (photograph courtesy of U.S. Geological Survey). 


\section{Anthropogenic Organic Compounds in Ground Water and Finished Water of Community Water Systems in the Northern Tampa Bay Area, Florida, 2002-04}

By Patricia A. Metz, Gregory C. Delzer, Marian P. Berndt, Christy A. Crandall, and Patricia L. Toccalino

NATIONAL WATER-QUALITY ASSESSMENT PROGRAM

SOURCE WATER-QUALITY ASSESSMENT

Scientific Investigations Report 2006-5267 


\section{U.S. Department of the Interior DIRK KEMPTHORNE, Secretary}

\section{U.S. Geological Survey \\ Mark D. Myers, Director}

\section{U.S. Geological Survey, Reston, Virginia: 2007}

For product and ordering information:

World Wide Web: http://www.usgs.gov/pubprod

Telephone: 1-888-ASK-USGS

For more information on the USGS--the Federal source for science about the Earth, its natural and living resources, natural hazards, and the environment:

World Wide Web: http://www.usgs.gov

Telephone: 1-888-ASK-USGS

Any use of trade, product, or firm names is for descriptive purposes only and does not imply endorsement by the U.S. Government.

Although this report is in the public domain, permission must be secured from the individual copyright owners to reproduce any copyrighted materials contained within this report.

Suggested citation:

Metz, P.A., Delzer, G.C., Berndt, M.P., Crandall, C.A., and Toccalino, P.L., 2007, Anthropogenic organic compounds in ground water and finished water of community water systems in the northern Tampa Bay area, Florida, 2002-04: U.S. Geological Survey Scientific Investigations Report 2006-5267, 48 p. 


\section{FOREWORD}

The U.S. Geological Survey (USGS) is committed to providing the Nation with accurate and timely scientific information that helps enhance and protect the overall quality of life and that facilitates effective management of water, biological, energy, and mineral resources (http://www.usgs.gov/). Information on the quality of the Nation's water resources is critical to assuring the long-term availability of water that is safe for drinking and recreation and suitable for industry, irrigation, and habitat for fish and wildlife. Population growth and increasing demands for multiple water uses make water availability, now measured in terms of quantity and quality, even more essential to the long-term sustainability of our communities and ecosystems.

The USGS implemented the National Water-Quality Assessment (NAWQA) Program in 1991 to support national, regional, and local information needs and decisions related to water-quality management and policy (http://water.usgs.gov/nawqa). Shaped by and coordinated with ongoing efforts of other Federal, State, and local agencies, the NAWQA Program is designed to answer: What is the condition of our Nation's streams and ground water? How are the conditions changing over time? How do natural features and human activities affect the quality of streams and ground water, and where are those effects most pronounced? By combining information on water chemistry, physical characteristics, stream habitat, and aquatic life, the NAWQA Program aims to provide science-based insights for current and emerging water issues and priorities.

From 1991-2001, the NAWQA Program completed interdisciplinary assessments in 51 of the Nation's major river basins and aquifer systems, referred to as Study Units (http://water.usgs.gov/nawqa/studyu.html). Baseline conditions were established for comparison to future assessments, and long-term monitoring was initiated in many of the basins. During the next decade, 42 of the 51 Study Units will be reassessed so that 10 years of comparable monitoring data will be available to determine trends at many of the Nation's streams and aquifers. The next 10 years of study also will fill in critical gaps in characterizing water-quality conditions, enhance understanding of factors that affect water quality, and establish links between sources of contaminants, the transport of those contaminants through the hydrologic system, and the potential effects of contaminants on humans and aquatic ecosystems. 
The USGS aims to disseminate credible, timely, and relevant science information to inform practical and effective water-resource management and strategies that protect and restore water quality. We hope this NAWQA publication will provide you with insights and information to meet your needs, and will foster increased citizen awareness and involvement in the protection and restoration of our Nation's waters.

The USGS recognizes that a national assessment by a single program cannot address all water-resource issues of interest. External coordination at all levels is critical for a fully integrated understanding of watersheds and for cost-effective management, regulation, and conservation of our Nation's water resources. The NAWQA Program, therefore, depends on advice and information from other agencies-Federal, State, interstate, Tribal, and local—as well as nongovernmental organizations, industry, academia, and other stakeholder groups. Your assistance and suggestions are greatly appreciated.

Robert M. Hirsch Associate Director for Water 


\section{Contents}

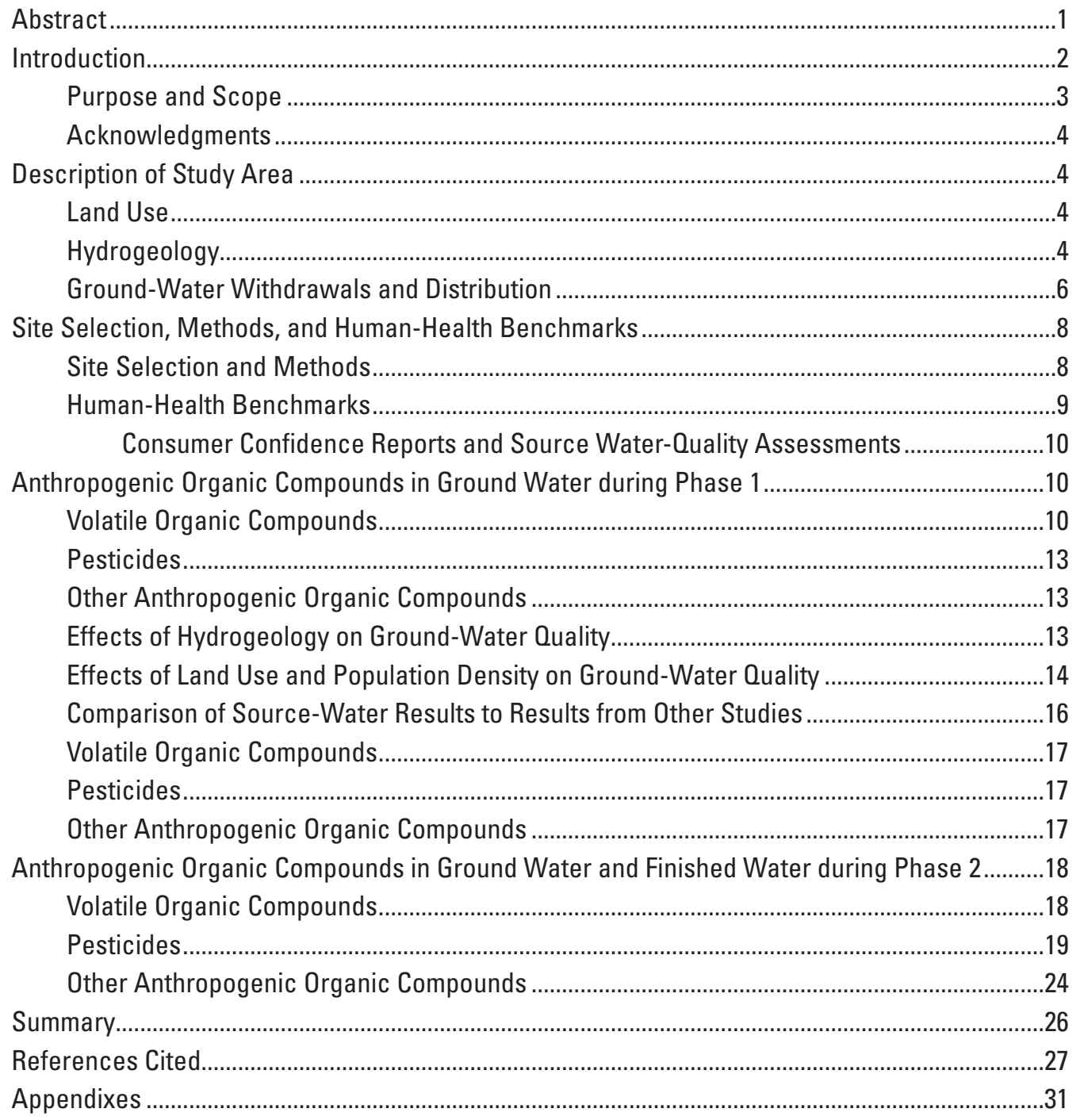




\section{Figures}

1-2. Maps showing:

1. Location of National Water-Quality Assessment Study Units and Ground-Water Source Water-Quality Assessments. .3

2. Location and land use of the study area..

3. Graph showing generalized hydrogeologic section of the study area...

4. Map showing distribution of the intermediate confining unit overlying the Upper Floridan aquifer and location of wells sampled in phase 1 and source-water wells where the associated finished water also was sampled in phase 2 of the study.

5. Photographs showing example of two treatment facilities located in the study area .....8

6-11. Graphs showing:

6. Concentrations, number of detections, and benchmark quotient values for volatile organic compounds, pesticides, and other anthropogenic organic compounds from 30 source-water wells during phase 1 ......

7. Concentrations of all detected anthropogenic organic compounds in source water from semiconfined and unconfined areas of the Upper Floridan aquifer during phase 1 .

8. Number of anthropogenic organic compound detections in source-water samples collected during phase 1 in comparison to population surrounding source-water wells in unconfined or semiconfined areas, and statistical relations with population

9. Detected volatile organic compounds in source water and associated finished water (non-blended and blended) during phase 2 showing concentrations and number of detections, and benchmark quotient values.

10. Detected pesticides in source water and associated finished water (nonblended and blended) during phase 2 showing concentrations and number of detections, and benchmark quotient values.

11. Detected anthropogenic organic compounds in source water and associated finished water (blended) during phase 2 showing concentrations and number of detections, and benchmark quotient values.

\section{Tables}

1. Maximum concentration, detection frequency, and maximum benchmark quotient for regulated and unregulated compounds detected in samples from 30 source-water wells of community water systems in the northern Tampa Bay area

2. Summary of locally conducted ground-water quality studies that evaluated the occurrence of volatile organic compounds, pesticides, and (or) other anthropogenic organic compounds

3 Maximum concentrations, detection frequency, and maximum benchmark quotient for regulated and unregulated compounds detected in samples collected during phase 2 from 11 source-water wells and the associated finished water of community water systems in the northern Tampa Bay Area... 
Appendixes 1-8.

1. Volatile organic compounds analyzed in this study................................................33

2. Pesticides and pesticide degradates analyzed in this study ..................................36

3. Other anthropogenic organic compounds analyzed in this study...........................40

4. Descriptions of human-health benchmarks related to drinking water....................42

5. Comparison of volatile organic compounds (VOCs) detected in the source water during phase 1 of the Source Water-Quality Assessment (SWQA) with VOCs detected in other local and regional studies.

6. Comparison of pesticides detected in the source water during phase 1 of the Source Water-Quality Assessment (SWQA) with pesticides detected in other local and regional studies

7. Comparison of other anthropogenic organic compounds (OAOCs) detected in the source water during phase 1 of the Source Water-Quality Assessment (SWQA) with OAOCs detected in a local study

8. Comparison between source and associated finished water for anthropogenic organic compounds detected during phase 2 of the Source Water-Quality Assessment

\section{Conversion Factors, Datum, Abbreviations, Acronyms, and Definitions}

\begin{tabular}{|c|c|c|}
\hline Multiply & By & To obtain \\
\hline \multicolumn{3}{|c|}{ Length } \\
\hline foot $(\mathrm{ft})$ & 0.3048 & meter $(\mathrm{m})$ \\
\hline mile (mi) & 1.609 & kilometer $(\mathrm{km})$ \\
\hline \multicolumn{3}{|c|}{ Area } \\
\hline acre & 4,047 & square meter $\left(\mathrm{m}^{2}\right)$ \\
\hline acre & 0.4047 & hectare (ha) \\
\hline acre & 0.4047 & square hectometer $\left(\mathrm{hm}^{2}\right)$ \\
\hline acre & 0.004047 & square kilometer $\left(\mathrm{km}^{2}\right)$ \\
\hline square miles $\left(\mathrm{mi}^{2}\right)$ & 2.590 & square kilometer $\left(\mathrm{km}^{2}\right)$ \\
\hline \multicolumn{3}{|c|}{ Volume } \\
\hline gallon (gal) & 3.7854 & liter $(\mathrm{L})$ \\
\hline \multicolumn{3}{|c|}{ Flow rate } \\
\hline gallon per minute ( $\mathrm{gal} / \mathrm{min})$ & 0.06309 & liter per second $(\mathrm{L} / \mathrm{s})$ \\
\hline gallon per day (gal/d) & 0.003785 & cubic meter per day $\left(\mathrm{m}^{3} / \mathrm{d}\right)$ \\
\hline million gallons per day $(\mathrm{Mgal} / \mathrm{d})$ & 0.04381 & cubic meter per day $\left(\mathrm{m}^{3} / \mathrm{d}\right)$ \\
\hline inch per year (in/yr) & 25.4 & millimeter per year $(\mathrm{mm} / \mathrm{yr})$ \\
\hline \multicolumn{3}{|c|}{ Concentration } \\
\hline parts per billion (ppb) & 1.0 & micrograms per liter $(\mu \mathrm{g} / \mathrm{L})$ \\
\hline
\end{tabular}

Horizontal coordinate information is referenced to the North American Datum of 1983 (NAD 83).

Vertical coordinate information is referenced to the North American Vertical Datum of 1929 (NGVD 29).

Concentrations of chemical constituents in water are given in micrograms per liter ( $\mu \mathrm{g} / \mathrm{L})$. 


\section{Abbreviations and Acronyms}

$\begin{array}{ll}< & \text { less than } \\ \mu & \text { greater than } \\ \text { AOC } & \text { micrograms per liter } \\ \text { BO } & \text { anthropogenic organic compound } \\ \text { BOmax } & \text { benchmark quotient } \\ \text { CASR } & \text { ratio of the maximum concentration to a drinking-water benchmark } \\ \text { CCR } & \text { Chemical Abstracts Service Registry } \\ \text { CWS } & \text { Consumer Confidence Report } \\ \text { DBP } & \text { community water system } \\ \text { DEET } & \text { disinfection by-product } \\ \text { E } & \text { N,N-diethyl-meta-toluamide } \\ \text { GAFL } & \text { estimated concentration } \\ \text { GC/MS } & \text { Georgia-Florida Coastal Plain } \\ \text { GIS } & \text { gas chromatography-mass spectrometry } \\ \text { HBSL } & \text { geographic information system } \\ \text { MAS } & \text { Health-Based Screening Level } \\ \text { MCL } & \text { major aquifer study } \\ \text { MRL } & \text { Maximum Contaminant Level } \\ \text { MTBE } & \text { maximum reporting level } \\ \text { NAWQA } & \text { methyl tert-butyl ether } \\ \text { NWOL } & \text { National Water-Quality Assessment } \\ \text { OAOC } & \text { National Water Quality Laboratory } \\ \text { PCE } & \text { other anthropogenic organic compound } \\ \text { SWOA } & \text { perchloroethene } \\ \text { TCEP } & \text { Source Water-Quality Assessment } \\ \text { TCPP } & \text { tri(2-chloroethyl)phosphate } \\ \text { ULUS } & \text { trildichloroisopropyl)phosphate } \\ \text { USEPA } & \text { urban land-use study } \\ \text { USGS } & \text { U.S. Environmental Protection Agency } \\ \text { VOC } & \text { U.S. Geological Survey } \\ & \text { volatile organic compound } \\ \end{array}$




\section{Definitions}

Terms for which definitions are provided below are presented in boldface type when first used in the text

Benchmark quotient (BO) Ratio of the concentration of a contaminant to its Maximum Contaminant Level (MCL) value for a regulated compound or to its Health-Based Screening Level (HBSL) value for an unregulated compound. BOs greater than 1 identify concentrations of potential human-health concern. B0s greater than 0.1 identify compounds that may warrant inclusion in a low-concentration, trends-monitoring program.

BOmax

Blended water

Ratio of the maximum concentration of a contaminant to its MCL or HBSL value.

As used in this report, finished water that has been blended with one or more different ground-water sources. Finished water blended with surface water was not sampled as part of this study.

Concentration of potential

As used in this report: (1) for a regulated compound with a human-health concern U.S. Environmental Protection Agency (USEPA) drinkingwater standard, a concentration greater than the Maximum Contaminant Level; and (2) for an unregulated compound, a concentration greater than the Health-Based Screening Level.

Community water system (CWS)

A public water system with 15 or more connections and serving 25 or more year-round residents and thus is subject to USEPA regulations enforcing the Safe Drinking Water Act. A community water system serves a residential population, such as a municipality, mobile home park, or nursing home.

Drinking-water guideline

As used in this report, a threshold concentration that has no regulatory status, but is issued in an advisory capacity by the USEPA or State agencies.

Drinking-water standard As used in this report, a threshold concentration that is legally enforceable (such as MCLs) by the USEPA or State agencies.

Finished water

Water is "finished" when it has passed through all the processes in a water treatment plant and is ready to be delivered to consumers.

Health-Based Screening Benchmark concentrations of contaminants in water that may

Level (HBSL) be of potential concern for human health, if exceeded. HBSLs are non-enforceable benchmarks that were developed by the U.S. Geological Survey (USGS) in collaboration with USEPA and others using USEPA methodologies for establishing drinkingwater guidelines and the most current, USEPA peer-reviewed, publicly available human-health toxicity information.

Human-health benchmarks As used in this report, these include USEPA and Florida Department of Environmental Protection (FDEP) MCL values and HBSL values developed collaboratively by the USGS, USEPA, New Jersey Department of Environmental Protection, and Oregon Health \& Science University. 
Maximum Contaminant Level (MCL)

Regulated compound

Source water

Unregulated compound
Legally enforceable standard that sets the maximum permissible level of a contaminant in water that is delivered to any user of a public water system. MCLs are set as close as feasible to Maximum Contaminant Level Goals (MCLGs). An MCLG is the maximum level of a contaminant in drinking water at which no known or anticipated adverse effect on the health of persons would occur, and which allows an adequate margin of safety. MCLGs are non-enforceable public health goals that take into account the best available technology, treatment techniques, cost considerations, expert judgment, and public comments.

As used in this report, a compound for which a Federal and (or) State drinking-water standard has been established.

Source water is the raw (ambient) water collected at the supply well or surface-water intake prior to water treatment used to produce finished water.

As used in this report, a compound for which no Federal and (or) State drinking-water standard has been established. Note that a compound that is unregulated under the Safe Drinking Water Act may be regulated in other contexts and under other statutes. 


\title{
Anthropogenic Organic Compounds in Ground Water and Finished Water of Community Water Systems in the Northern Tampa Bay Area, Florida, 2002-04
}

\author{
By Patricia A. Metz, Gregory C. Delzer, Marian P. Berndt, Christy A. Crandall, and Patricia L. Toc calino
}

\section{Abstract}

As part of the U.S. Geological Survey's (USGS's) National Water-Quality Assessment (NAWQA) Program, a Source Water-Quality Assessment (SWQA) was conducted in the unconfined and semiconfined portions of the Upper Floridan aquifer system during 2002-04. SWQAs are twophased sampling activities, wherein phase 1 was designed to evaluate the occurrence of 258 anthropogenic organic compounds (AOCs) in ground water used as source water for 30 of the largest-producing community water system (CWS) wells in the northern Tampa Bay area, Florida. The 258 AOCs included volatile organic compounds (VOCs), pesticides, and other anthropogenic organic compounds (OAOCs). Phase 2 was designed to monitor concentrations in the source water and also the finished water of CWSs for compounds most frequently detected during phase 1 .

During phase 1 of the SWQA study, 31 of the 258 AOCs were detected in source-water samples collected from CWS wells at low concentrations (less than 1.0 microgram per liter $(\mu \mathrm{g} / \mathrm{L}))$. Twelve AOCs were detected in at least 10 percent of samples. Concentrations from 16 of the 31 detected AOCs were about 2 to 5 orders of magnitude below human-health benchmarks indicating that concentrations were unlikely to be of potential human-health concern. The potential humanhealth relevance for the remaining 15 detected unregulated AOCs could not be evaluated because no human-health benchmarks were available for these compounds.

Hydrogeology, population, and land use were examined to evaluate the effects of these variables on the source water monitored. Approximately three times as many detections of VOCs (27) and pesticides (34) occurred in unconfined areas than in the semiconfined areas ( 8 VOCs, 14 pesticides). In contrast, 1 OAOC was detected in unconfined areas, and 13 OAOCs were detected in semiconfined areas with 9 of the OAOC detections occurring in samples from two wells located near septic systems. Analyses of population and land use indicated that the number of compounds detected increased as the population surrounding each well increased. Detection frequencies and concentrations for VOCs (particularly chloroform) and pesticides were highest in residential land-use areas.

The results of source-water samples from the $30 \mathrm{CWS}$ wells monitored during phase 1 of this SWQA study were compared to four locally conducted studies. These general comparisons indicate that the occurrence of VOCs in other studies is similar to their occurrence in source water of CWSs monitored as part of this SWQA. However, pesticide compounds, especially atrazine and its breakdown products, occurred more frequently in the SWQA study than in the other four studies.

Phase 2 of the SWQA assessed AOCs in samples from 11 of the $30 \mathrm{CWS}$ wells and the associated finished water. Overall, 42 AOCs were detected in either source water or finished water and more compounds were detected in finished water than in source water. Specifically, 22 individual AOCs were detected in source water and 27 AOCs were detected in finished water. The total number of detections was greater in the finished water (80) than in the source water (49); however, this was largely due to the creation of disinfection by-products (DBPs) during water treatment. Excluding DBPs, about the same number of total detections was observed in source water (40) and finished water (44).

During phase 2, AOC detected concentrations ranged from E0.003 (estimated) to $1,140 \mu \mathrm{g} / \mathrm{L}$ in the source water and from E0.003 to $36.3 \mu \mathrm{g} / \mathrm{L}$ in the finished water. Concentrations of 24 of the 42 compounds were compared to human-health benchmarks and were about 1 to 5 orders of magnitude below their human-health benchmarks indicating that concentrations are unlikely to be of potential human-health concern, excluding DBPs. Concentrations of carbon tetrachloride, however, were within 10 percent of its human-health benchmark, which is considered a level that may warrant inclusion of the compound in a low-concentration, trendsmonitoring program. The potential human-health relevance for the remaining 18 detected unregulated AOCs could not be evaluated because no human-health benchmarks were available for these compounds.

The source-water results were compared with the associated finished water results. On the basis of this 
comparison, it appears that additional data are needed to determine how source water compares to finished water. In this study, the occurrence of VOCs in source water does not necessarily characterize the occurrence of VOCs in finished water, especially because 14 of 18 detected VOCs occurred in the source water or finished water, but not both. In contrast, monitoring selected pesticides in source water (especially atrazine and its breakdown products) may approximate the occurrence of these pesticides in finished water. However, the effect of blending makes it difficult to compare source water to finished water without monitoring all CWS wells that contribute to blended finished water.

\section{Introduction}

In 1991, the U.S. Geological Survey (USGS) began the National Water-Quality Assessment (NAWQA) Program to (1) provide a nationally consistent description of current water-quality conditions for more than 50 of the largest and most important river basins and aquifers across the Nation; (2) define long-term trends in water quality; and (3) identify, describe, and explain, as possible, the major factors that affect observed water-quality conditions and trends. This information, which is obtained on a continuing basis, is made available to water managers, policy makers, and the public to help address and prioritize the multitude of issues related to managing and protecting our water resources.

Beginning in 2001, the NAWQA Program began its second decade of intensive assessment activities by returning to 42 of the original river basins and aquifers studied during the first decade (fig. 1). The second decade of assessments is designed to build upon the initial assessments of water-quality conditions and establish links between sources, transport, and the potential effects of contaminants on humans and aquatic ecosystems. This will be accomplished through a variety of new, focused study components within the NAWQA Program. One such new assessment activity focuses on characterizing the water quality of major rivers and aquifers used as a source of supply to larger community water systems (CWSs) located in many of the original 42 basins studied. These activities are called Source Water-Quality Assessments (SWQAs) and are intended to complement drinking-water monitoring required by Federal, State, and local programs, which focus primarily on post-treatment compliance monitoring. Through SWQAs, NAWQA is increasing its emphasis on characterizing water-quality of rivers and aquifers that are major sources of drinking water and will continue to collaborate with other agencies and organizations involved with supplying and managing drinking water.

One ground-water SWQA study was completed in the Georgia-Florida Coastal Plain (GAFL) Study Unit during 2002-04. The GAFL Study Unit (fig. 1) includes northern Florida and central Georgia, which covers an area about 61,000 square miles $\left(\mathrm{mi}^{2}\right)$. In 2000 , approximately 3 billion gallons per day of ground water was withdrawn in the Study Unit with more than 90 percent of withdrawals from the Floridan aquifer system (R.L. Marella, U.S. Geological Survey, written commun., 2005). As a result, the northern Tampa Bay area (fig. 2) was chosen for an SWQA because of the large population that relies heavily on the ground-water resources from the Upper Floridan aquifer system.

The water-quality sampling for SWQAs consists of two phases. Phase 1 focuses on determining the occurrence of 258 anthropogenic organic compounds (AOCs) (Appendixes 1,2 , and 3) in the source water of some of the largest CWS wells in the Study Units. The occurrence of AOCs in the source water and the associated finished water is assessed during phase 2 for those AOCs detected most frequently during phase 1. Currently (2006), 12 ground-water SWQAs have been completed and 3 more will be completed by NAWQA during the year.

The AOCs monitored as part of SWQAs include volatile organic compounds (VOCs), pesticides, and other anthropogenic organic compounds (OAOCs). VOCs are a subset of organic chemicals that have been produced and used in a variety of commercial, industrial, and household applications for many decades and are a major component or additive to gasoline, paints, varnishes, glues, dyes, and plastics. Pesticides are used extensively throughout the United States to increase crop yields; enhance the aesthetics of lawns, gardens, golf courses, and recreational areas; and protect the safety of the public from insect-associated diseases. The widespread use of pesticides over the past several decades has led to their frequent detection in ground water (Barbash and Resek, 1996). OAOCs represent a group of compounds that are present in a wide variety of products commonly used in homes, industry, and agriculture including personal-care and domestic-use products, plant- or animal-derived biochemicals, and fumigants. Little is known about the environmental occurrence, transport, and ultimate fate of OAOCs after their intended use. However, it is known that these compounds often are released directly to the environment after passing through wastewater-treatment plants or domestic septic systems, which often are not designed to remove these compounds from the effluent (Herberer, 2002; Ternes and others, 2002). Until recently, few analytical methods were capable of detecting these compounds at low concentrations that might be expected in the environment.

The purpose of many USGS water-quality studies is to assess the occurrence of contaminants in the Nation's water resources (ambient water-quality assessments, hereafter referred to as other studies) and little emphasis is placed specifically on source water and even less emphasis is placed on finished water. In SWQAs, source water includes waters from CWS wells, and finished water represents source water that has been treated (at least disinfected) prior to distribution. Finished water may be composed of water from multiple CWS wells (blended water) or it may be composed only of water from one CWS well and treated at (or near) the well (nonblended). 


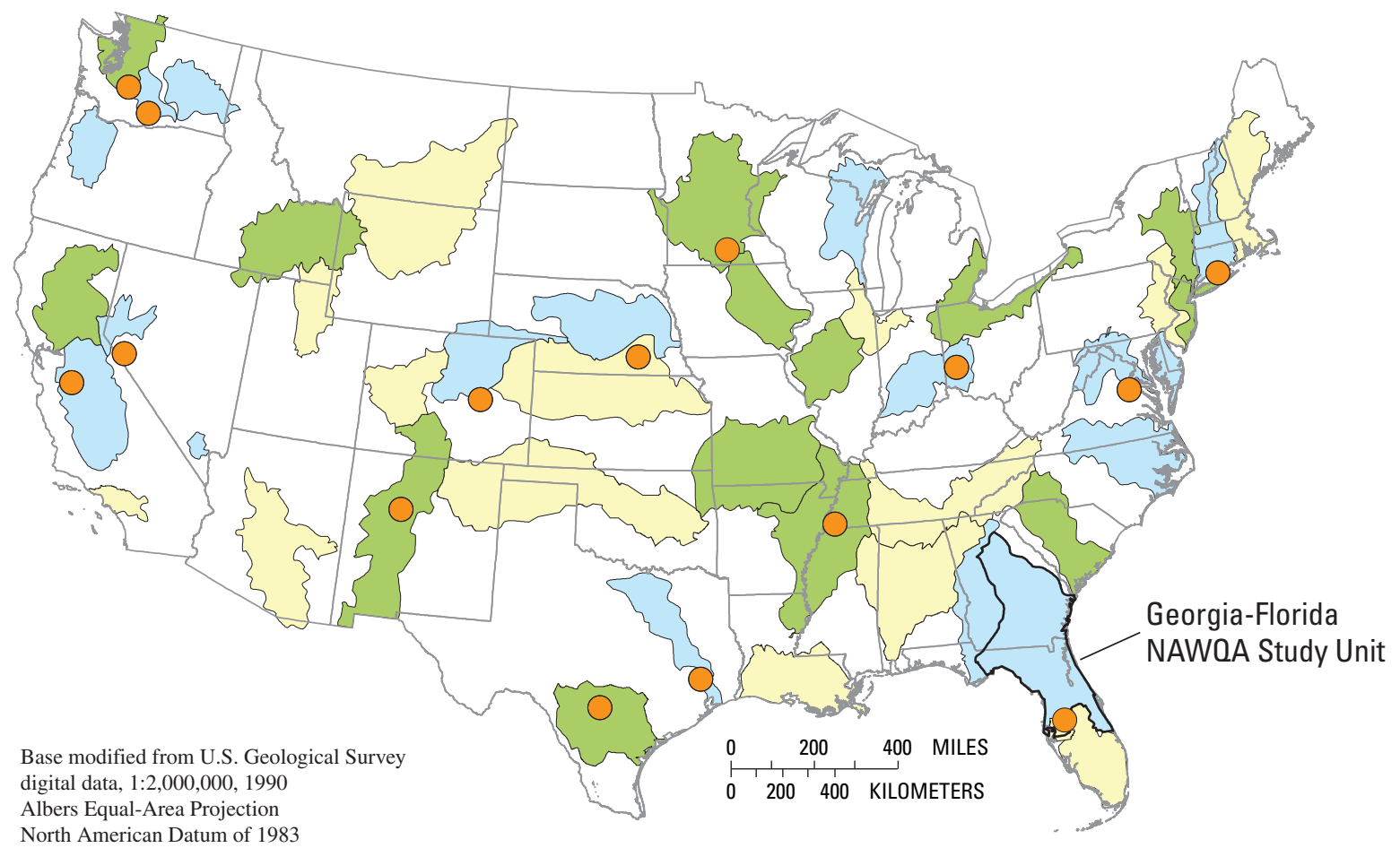

North American Datum of 198

EXPLANATION

NAWQA Study Units-Scheduled to begin in fiscal year:

2001

2004

2007
Ground-Water Source Water-Quality

Assessment location

Figure 1. Location of National Water-Quality Assessment (NAWQA) Study Units and Ground-Water Source WaterQuality Assessments.

Because most other studies do not provide direct linkage to source water of CWSs due to the type of well sampled (such as monitoring and domestic wells), a need exists to, at minimum, qualitatively determine how representative results from other studies conducted by the USGS are of source water used by large and very large CWSs. This qualitative representation may be accomplished by comparison of results from other studies with those from SWQAs. Similarly, because the application of various treatment technologies alters the water chemistry of source water to meet various Federal and State drinking-water requirements, a need exists to better understand how representative source-water results are of finished water prior to distribution. A sequential comparison of results from other studies with source water and a separate comparison of source water with finished water may begin to characterize the overall representative nature of other studies conducted by USGS on the quality of finished water prior to distribution. Linking these types of studies is important, especially considering the documented occurrence of AOCs in finished water at concentrations similar to those found in source water (Stackelberg and others, 2004; Loraine and Pettigrove, 2006) and in simulated drinking-water treatment processes (Westerhoff and others, 2005). Thus, data obtained through SWQAs characterize not only the quality of source water and finished water of some of the larger CWSs prior to distribution but also begin to provide a mechanism to bring results obtained from other studies into context with water used for human consumption.

\section{Purpose and Scope}

The purpose of this report is to describe the occurrence of AOCs in ground water and finished water of CWSs in the northern Tampa Bay area during 2002-04. The SWQA results are compared to findings from selected ambient water-quality assessments that monitored the same compounds using the same field and analytical techniques.

For the assessment of ground water, this report describes the occurrence of 258 AOCs in source water obtained from 30 of the largest producing CWS wells (source-water wells) in the northern Tampa Bay area. One-half of the CWS wells were screened in unconfined areas, and one-half were screened in semiconfined areas of the Upper Floridan aquifer. In addition, 
the effects of hydrogeology, as well as land use and population density, on the water quality in these settings are described for the 30 CWS wells.

This report also presents a comparison of the SWQA results from the source-water samples from $30 \mathrm{CWS}$ wells to results from four other locally conducted studies. Specifically, results are compared to three studies of the Upper Floridan aquifer and one study of the Biscayne aquifer in Miami-Dade, Broward, and Palm Beach Counties, Florida.

Finally, this report describes the occurrence of selected AOCs in samples from 11 of the $30 \mathrm{CWS}$ wells and in the associated finished water. Concentrations are compared to USEPA Maximum Contaminant Levels (MCLs) and Health-Based Screening Levels (HBSLs) developed by the USGS in collaboration with USEPA and others to evaluate the potential relevance of the findings to human health.

\section{Acknowledgments}

The authors are grateful to the many public and private organizations for providing information pertaining to the wells used in this study and for permitting the collection of samples for water-quality analyses. The authors also express their appreciation for the technical discussions with John Troutt from Tampa Bay Water, Dave Slonena from Pinellas County Utilities, and Dave DeWitt from Southwest Florida Water Management District. The authors acknowledge USGS employees Jessica Hopple and Yvonne Stoker for their constructive review comments and Scott McBride, Terry Petrosky, and Darlene Blum for their help with field collection and data compilation.

\section{Description of Study Area}

The study area is approximately 2,000 $\mathrm{mi}^{2}$ and includes all of Pasco County and parts of Hernando, Pinellas, Hillsborough, and Polk Counties (fig. 2). The topography of the study area is characterized by flat, marshy lowlands along the coast, low rolling hills in the central region, and sand ridges and terraces that vary more than 200 feet (ft) in elevation in the northern and eastern regions. Hundreds of lakes, wetlands, and marshes are interspersed throughout the study area, ranging from less than an acre to more than 2,500 acres. Six rivers and their tributaries and several springs that discharge inland and along the coast are located within the study area.

Warm, wet summers and relatively mild, dry springs characterize the subtropical climate of the study area. Rainfall varies seasonally with more than one-half the annual rainfall typically occurring during June through September. Long-term average rainfall for the south-central Georgia and peninsular Florida is about 53 inches per year (Bush and Johnston, 1988).

\section{Land Use}

The northern Tampa Bay area has experienced an increase in urbanization during the last 20 years, which has resulted in substantial land-use changes. The population increased from 1.1 million in 1980 to an estimated 2 million in 2003 (U.S. Census Bureau, 2002). Many of the land-use changes in the last 20 years can be attributed to increases in residential land use.

Geographic information system (GIS) land-use coverages were used to determine the land-use distribution within the study area (Vogelmann and others, 2001). Land use was grouped into six categories with the percentage of the total area occupied by each category as follows: residential (25 percent); wetlands and surface water (25 percent); open land and recreational (20 percent); agricultural (pasture and tree plantations, 18 percent); commercial, industrial, and transportation (8 percent); and agricultural (nurseries and farms, 4 percent) (fig. 2). The majority of residential and commercial land use is concentrated along the coast and in the southern area near Tampa Bay, whereas many of the wetlands, open-land and recreational, and agricultural land-use areas are located in the northern, central, and eastern regions of the study area.

\section{Hydrogeology}

The geologic units underlying the study area consist of sand, clay, and carbonate rocks that were deposited primarily in a marine environment. Deposition of each geologic formation was followed by a period of erosion that resulted in the development of surface irregularities and solution cavities in the limestone. The hydrogeologic setting of the study area is characterized by limited confinement between the land surface and underlying karst limestone, springs, several sinking streams, and more than 800 documented sinkholes. Principal hydrogeologic units include the surficial aquifer, the intermediate confining unit, and the Upper Floridan aquifer (fig. 3).

The uppermost unit, the surficial aquifer, is an unconfined sand and clay aquifer. The thickness of these surficial sediments ranges from about 10 to $60 \mathrm{ft}$. The water table of the surficial aquifer is at a relatively shallow depth below land surface (approximately 1 to $10 \mathrm{ft}$ ). Because of the shallow depth to the water table and the permeable sand deposits, the ground water in the surficial aquifer is affected by localized land-use practices (Metz and Sacks, 2002).

The intermediate confining unit is a nonwater-yielding layer that impedes the downward flow from the surficial aquifer. The confining unit consists of dense, marine, plastic clay that contains varying amounts of sand, chert, and carbonate mud (Sinclair, 1974). The clay confining unit is variable in extent, thickness, and permeability throughout the study area. 


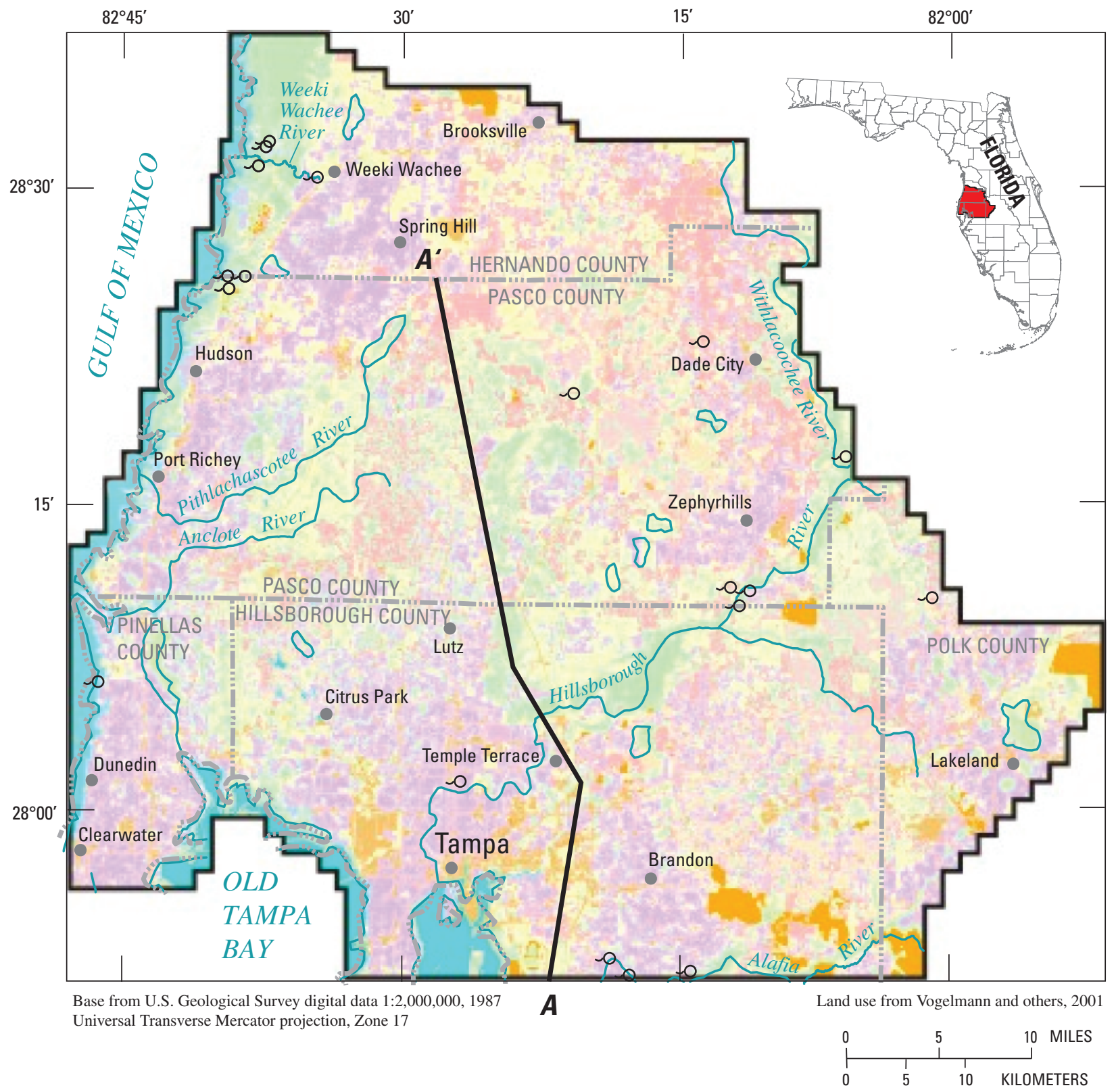

\section{EXPLANATION \\ $A$ A` Hydrogeologic section-Referenced in figure 3 \\ Land use \\ Residential \\ Wetlands and surface water \\ Open land and recreational \\ Agriculture (pasture and tree plantations) \\ Commercial, industrial, and transportation \\ Agriculture (nurseries and farms) \\ - General location of springs}

Figure 2. Location and land use of the study area. 


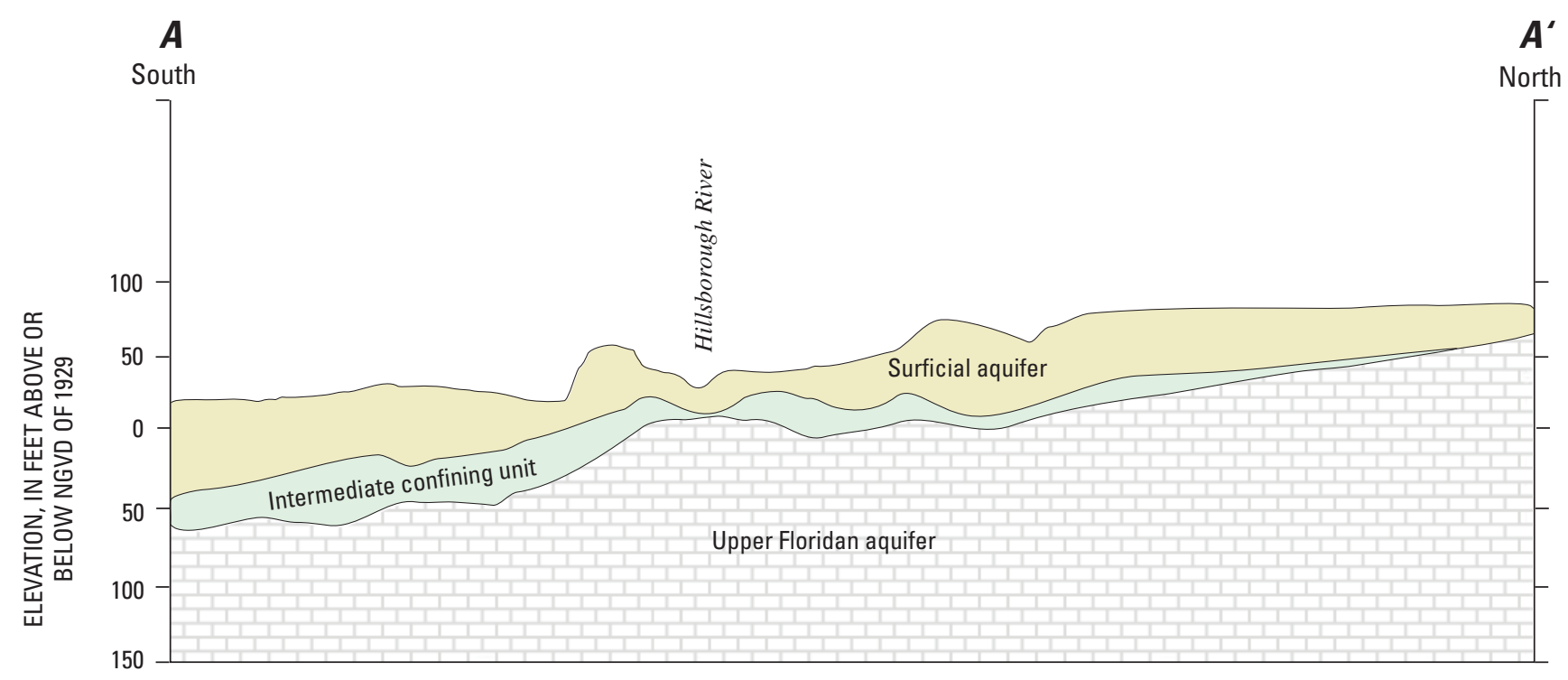

Figure 3. Generalized hydrogeologic section of the study area. Location of section is shown in figure 2.

Underlying the intermediate confining unit is the Upper Floridan aquifer, which is the major source of water supply within the study area. The aquifer is contained in a thick sequence of limestone and dolomite, which has many solutionenlarged fractures and cavities. Public-supply wells that tap this limestone and dolomite unit commonly yield several hundred to several thousand gallons per minute. For the purpose of this report, the following two areas of confinement for the Upper Floridan aquifer are distinguished within the study area: (1) an unconfined area, for which the intermediate confining unit ranges in thickness from zero to less than $5 \mathrm{ft}$; and (2) a semiconfined area for which the intermediate confining unit ranges in thickness from $5 \mathrm{ft}$ to more than $100 \mathrm{ft}$ (fig. 4).

\section{Ground-Water Withdrawals and Distribution}

The northern Tampa Bay area relies heavily on ground water for public supply. More than 700 public-supply wells are permitted for use within the study area. Public-supply water is used for a variety of purposes, such as domestic, commercial, industrial, and agricultural uses. These supply wells may be publicly or privately owned and operated, and the source water may be treated prior to distribution.

As used in this study, source water is the raw (ambient) water collected at the supply well prior to water treatment, blended water is a mixture of water from several ground-water sources, and finished water is the source water or blended water that is treated and ready to be delivered to consumers. Blended water, by definition, also could include a mixture of ground water and surface water; however, this study (as well as other ground-water SWQAs) only included systems that blended with other ground waters.

Much of the ground water supplied by CWSs within the study area is obtained from a regional system of 11 interconnected well fields. Withdrawals during 2000 were approximately 200 million gallons per day (Mgal/d) (R.L. Marella, U.S. Geological Survey, written commun., 2005). In this study, blended water typically was treated by several processes, including the addition of hypochlorous acid and ammonia to form chloramines (fig. 5A). Non-blended ground water typically is treated only with chlorine (fig. $5 B$ ) prior to entering the distribution system.

In addition to the well fields, hundreds of wells are permitted for small communities and municipalities within the study area. These wells cumulatively pump approximately $80 \mathrm{Mgal} / \mathrm{d}$ and range from serving less than 500 residents to the larger municipality wells serving more than 150,000 residents (R.L. Marella, U.S. Geological Survey, written commun., 2005). Water from these CWS wells are treated prior to distribution by a variety of methods including disinfection using chlorine gas, coagulation and filtration, adsorption, lime softening, addition of corrosion and $\mathrm{pH}$ control additives, and reverse osmosis. 


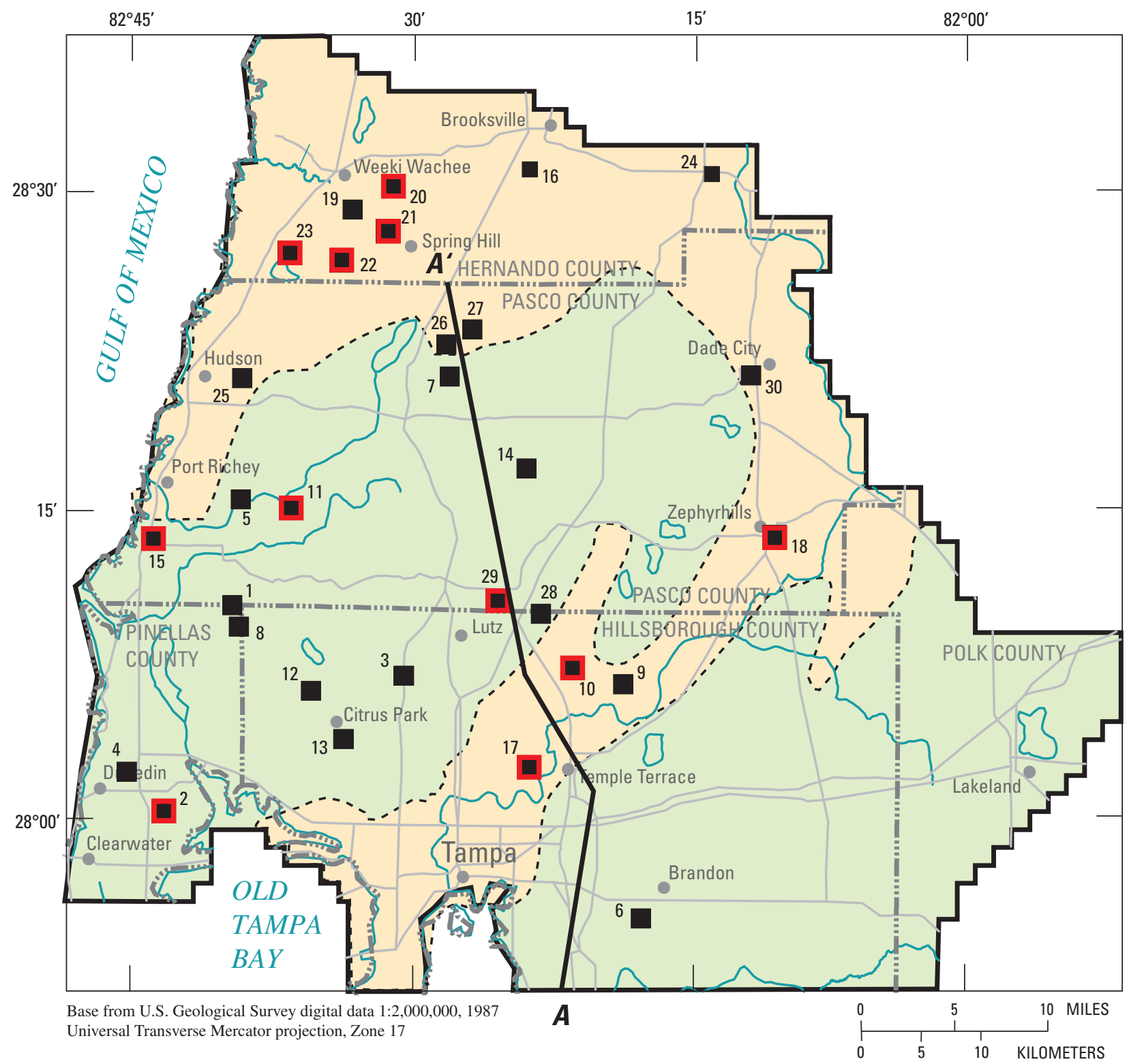

\section{EXPLANATION}

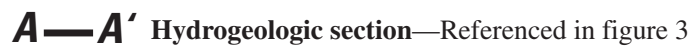

Upper Floridan aquifer

Unconfined area, confining unit 0 to 5 feet thick

Semiconfined area, confining unit 5 to more than 100 feet thick

- - - - Inferred geologic contact

6 Phase-one sampling - 30 source-water wells. Number is well identification

${ }^{17}$ Phase-two sampling-Resampling of 11 source-water and associated finished-water wells. Number is well identification

Figure 4. Distribution of the intermediate confining unit overlying the Upper Floridan aquifer and location of wells sampled in phase 1 and source-water wells where the associated finished water also was sampled in phase 2 of the study. 


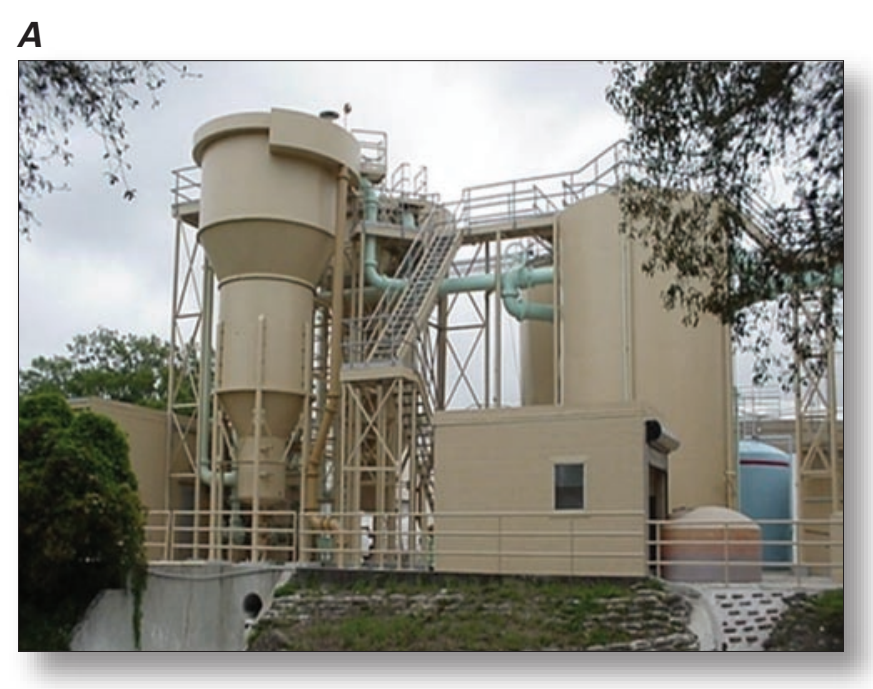

$\boldsymbol{B}$

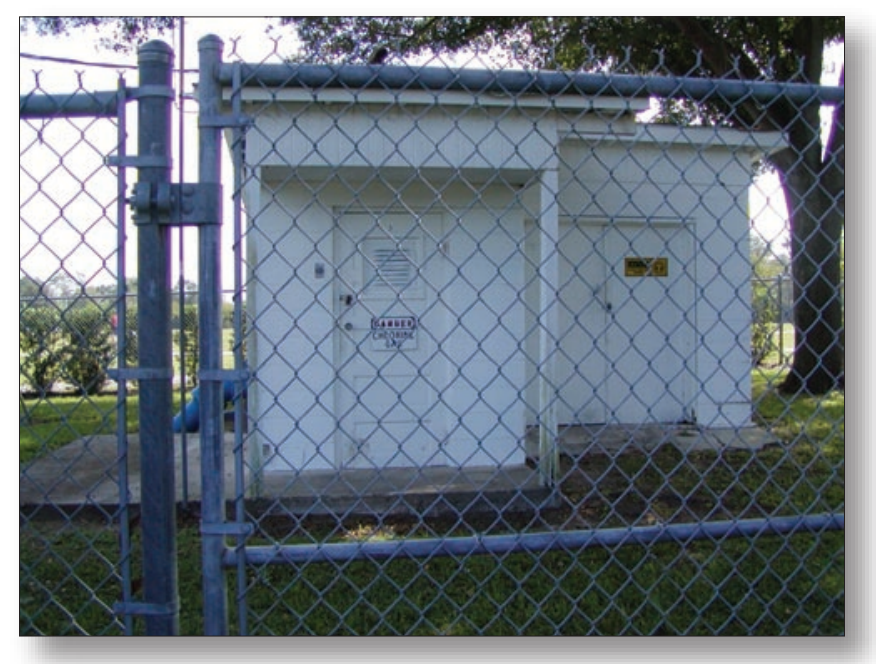

(A) Treatment plant that blends ground water from several source wells. Treatment is then performed on the blended water and distributed. $(B)$ Example of a non-blended well site where ground water is disinfected at the well and distributed to the nearby community.

Figure 5. Example of two treatment facilities located in the study area.

\section{Site Selection, Methods, and Human- Health Benchmarks}

This section describes the process used to select the sampled wells and the methods for sample collection and analyses. Regulatory and non-regulatory human-health benchmarks used in this report also are described, and a description of how water-quality results are interpreted in a human-health context is provided.

\section{Site Selection and Methods}

In phase 1 of the study, 30 public-supply wells serving CWSs were sampled to characterize the occurrence of anthropogenic compounds that may exist in ground water. To characterize the effects of hydrogeology on the groundwater quality, 15 wells in the unconfined areas and 15 wells in the semiconfined areas of the Upper Floridan aquifer were selected (fig. 4). The wells were selected from more than 700 CWS wells using a random computerized statistical process (Statistical Analysis System, 1989). The well selection process included selecting only wells in the upper 25 th percentile of pumping volume (withdrawals greater than about 200,000 gallons per day) with a minimum distance of 0.62 mile ( 1 kilometer) between well sites to minimize sampling the same volume of water from the aquifer. These highest producing wells (based on pumping volume) tend to stress the ground-water systems more, have a larger cone of depression, and hence are more likely to capture anthropogenic contaminants than lower producing wells. Wells were sampled in October 2002 through January 2003 for 88 VOCs, 120 pesticides, and 50 OAOCs (Appendixes 1, 2, and 3 , respectively).

During phase 2 of the study, 11 of the 30 wells were selected for resampling in August and September 2004 on the basis of the occurrence of AOCs detected most frequently in phase 1 (fig. 4). Samples of both source water and the associated finished water from 10 wells were analyzed for VOCs, 6 wells for pesticides, and 2 wells for OAOCs.

Ground-water samples were collected using established USGS protocols (Koterba and others, 1995), and finishedwater samples were collected after treatment and prior to the water entering transport pipelines. Finished-water samples typically contain free chlorine, which has been documented to degrade certain organic compounds that may be present in the water samples (Winslow and others, 2001). Therefore, a dechlorination reagent (ascorbic acid) and, for certain contaminant groups, $\mathrm{pH}$ buffers were added to finished-water samples during sample collection to stabilize them prior to analyses. The addition of these dechlorination reagents to water samples was tested in a laboratory setting, and results indicated that they did not interfere with the analytical 
performance (Mark Sandstrom, USGS National Water Quality Laboratory, oral commun., 2004).

All samples were analyzed at the USGS National Water Quality Laboratory (NWQL) in Denver, Colorado. Water samples were analyzed for VOCs using purge and trap capillary column gas chromatography/mass spectrometry (GC/MS) (Connor and others, 1998) and for pesticides using capillary column GC/MS (Zaugg and others, 1995; Lindley and others, 1996; Furlong and others, 2001; Sandstrom and others, 2001; Madsen and others, 2003). Water samples were analyzed for OAOCs using solid-phase extraction and capillary-column GC/MS (Zaugg and others, 2002). Data are presented in Carter and others (2007).

The minimum reporting level (MRL) is the smallest measured concentration of a constituent that may be reliably reported using a given analytical method (Timme, 1995). Concentrations greater than (>) the MRL are reported as detected concentrations. Some analyte concentrations were flagged with an "E" to indicate estimated values. Concentrations are estimated when a compound is found to be present in a water sample but the concentration is less than the lowest-daily calibration standard.

Quality-assurance/quality-control samples were collected following methods by Koterba and others (1995). All SWQA data are reviewed on an annual basis to evaluate systematic contamination. If systematic contamination is identified, those data are removed from the data set and not used in subsequent data analyses (D.A. Bender (VOCs), J.A. Hopple (pesticides), and J.A. Kingsbury (OAOCs), U.S. Geological Survey, written commun., 2006). Field-blank samples collected as part of the GAFL SWQA did not contain any compounds detected in source or finished water with the exception of N,N-diethylmeta-toluamide (DEET). DEET was detected in one fieldblank sample collected during phase 1; however, it was not detected in any blanks collected during phase 2 . Because the DEET detection in one blank sample was not considered to be representative of systematic contamination, DEET results were retained in the data set. However, the overall effect of the DEET detection in one blank sample is not fully understood, and needs to be considered in subsequent interpretations.

\section{Human-Health Benchmarks}

The USGS began an interagency pilot effort in 1998 to communicate the importance of water-quality findings of the NAWQA Program in a human-health context. Historically, the USGS has assessed water-quality conditions by comparing measured concentrations with human-health benchmarks such as established Federal or State drinking-water standards and guidelines. The drinking-water standards for regulated compounds are called MCLs, which are legally enforceable standards that set the maximum permissible level of a contaminant in water that is delivered to any user of a public water system. MCLs are set as close as feasible to the maximum level of a contaminant at which no known or anticipated adverse effects on human health would occur, taking into account the best available technology, treatment techniques, cost considerations, expert judgment, and public comments (U.S. Environmental Protection Agency, 2006).

Federal drinking-water standards and guidelines currently (2006) are not available for nearly one-half of the organic compounds most frequently analyzed by the NAWQA Program and other USGS studies (Toccalino and others, 2005). In order to provide a more complete understanding of the human-health relevance of water-quality data collected, existing Federal drinking-water standards and guidelines are supplemented by HBSL values calculated for unregulated compounds (compounds without Federal drinking-water standards). HBSLs were calculated using an approach that was developed collaboratively by the USGS, U.S. Environmental Protection Agency (USEPA), New Jersey Department of Environmental Protection, and Oregon Health \& Science University (Toccalino and others, 2003, 2004).

HBSLs are not legally enforceable regulatory standards, and water utilities are not required to compare contaminant monitoring results to HBSLs. HBSLs are benchmark concentrations of contaminants in water that may be of potential concern for human health, if exceeded, and can be used as threshold values against which contaminant concentrations in water samples can be compared to evaluate water-quality data in a human-health context. HBSLs can be used as planning tools to help prioritize contaminants that may merit further study or monitoring and to provide an early indication of contaminant concentrations of potential human-health concern in water resources (Toccalino and others, 2005). Appendix 4 provides descriptions of the humanhealth benchmarks that were used in this study.

To aid in evaluating water-quality data in the context of human health, benchmark quotient (BQ) values were calculated. A BQ value is the ratio of a measured concentration of a detected compound to its MCL (for a regulated compound) or HBSL (for an unregulated compound). For this study, the maximum concentration detected for each compound was used to calculate this ratio, called BQmax. A BQmax value greater than or equal to 1 was used to identify concentrations of potential human-health concern (hereafter referred to as concentrations of potential concern). A BQmax threshold value greater than or equal to 0.1 was used to identify compounds that may warrant inclusion in a low-concentration, trends-monitoring program; frequently occurring compounds (in this report, frequently occurring indicates an occurrence of an AOC in 10 percent or more of samples) also may warrant inclusion in such a monitoring program. Such monitoring allows for analyzing trends in their occurrence, may provide an early indication of contaminant levels that approach human-health benchmarks, and consequently, approach concentrations of potential human-health concern. 


\section{Consumer Confidence Reports and Source Water-Quality Assessments}

Since 1999, the U.S. Environmental Protection Agency (USEPA) has required water suppliers to provide annual drinking-water quality reports called Consumer Confidence Reports (CCRs) to their customers (http:// www.epa.gov/safewater/ccr/ccrfact.html). CCRs are the centerpiece of the right-to-know provisions of the 1996 Amendments to the Safe Drinking Water Act. Each CCR provides consumers with fundamental information about their drinking water including (1) the source of the drinking water, (2) a brief summary of the susceptibility to contamination of the local drinking-water source, (3) the concentrations (or range of concentrations) of any contaminants found in local drinking water, as well as their USEPA Maximum Contaminant Levels (MCLs), which are legally enforceable drinking-water standards and are the highest allowed concentrations of contaminants in drinking water, for comparison, and (4) phone numbers for additional sources of information.

Information in CCRs is specific to a particular water utility. Water utilities analyze finished-water samples primarily for regulated contaminants (that is, those with MCLs) using USEPA analytical methods for the purpose of compliance monitoring. In contrast, Source Water-Quality Assessments (SWQAs) performed by the USGS are not conducted for compliance monitoring and encompass data from multiple water utilities spatially distributed across the Nation. As part of SWQAs, both source- and finished-water samples are analyzed using USGS analytical methods, where source water is the raw (ambient) water collected at the surface-water intake or supply well prior to water treatment and finished water is the treated water sampled prior to entering the distribution system. USGS analytical methods used in SWQAs typically have lower analytical reporting levels than those used in compliance monitoring; therefore, contaminant detection frequencies reported in SWQA reports may be higher than detection frequencies for the same contaminants reported in CCRs. In SWQAs, concentrations of regulated and unregulated contaminants in source and finished water are compared to MCLs and Health-Based Screening Levels (HBSLs), respectively. HBSLs are benchmark concentrations of contaminants in water that may be of potential humanhealth concern, if exceeded, and are consistent with USEPA Office of Water methodologies for setting nonenforceable drinking-water guideline values. HBSLs are not legally enforceable regulatory standards, and water utilities are not required to compare contaminant monitoring results to HBSLs.

\section{Anthropogenic Organic Compounds in Ground Water during Phase 1}

A total of 31 of the 258 individual AOCs were detected (11 VOCs, 12 pesticides, and 8 OAOCs) in ground-water (source-water) samples collected from $30 \mathrm{CWS}$ wells sampled between October 2002 and January 2003 during phase 1 of the SWQA study (table 1). The 10 most frequently occurring AOCs were detected in at least 13 percent of the 30 sourcewater samples and included chloroform, deethylatrazine, atrazine, 2-hydroxyatrazine, bentazon, carbon disulfide, prometon, DEET, perchloroethene (PCE), and simazine. Samples generally contained a mixture of compounds (average of three compounds per sample), and 70 percent of the samples contained at least one AOC.

Concentrations for compounds detected in the source water were low (defined in this report as concentrations less than 1.0 microgram per liter $(\mu \mathrm{g} / \mathrm{L}))$. Concentrations were compared to their respective human-health benchmarks (MCLs for regulated compounds or HBSLs for unregulated compounds), which were available for 16 of the 31 detected compounds. Concentrations were about 2 to 5 orders of magnitude less than their human-health benchmarks, indicating that these concentrations are unlikely to be of potential human-health concern (table 1). The potential human-health relevance of the remaining 15 detected unregulated contaminants could not be evaluated because human-health toxicity information necessary to calculate HBSLs for these contaminants was not available. Additional monitoring may be warranted for frequently occurring AOCs (defined in this report as occurring in 10 percent or more of samples) that do not have human-health benchmarks, such as 1,2,4-trimethylbenzene, to better understand their spatial and temporal distribution, as well as sources, transport, and fate.

When comparing analytical results among different AOCs, it is important to consider the analytical MRL of each AOC. That is, an AOC may have a higher detection frequency in comparison to other AOCs that have higher MRLs. A true comparison is possible, however, when comparing individual compounds analyzed using the same analytical method (same MRL). For the purposes of this report, comparisons of AOCs are made among AOCs and between studies regardless of varying MRLs (Appendixes 1, 2, and 3) to characterize general occurrence rates and similarities, or the lack thereof, between these studies.

\section{Volatile Organic Compounds}

Eleven VOCs were detected in the source-water samples (table 1, fig. 6A). Chloroform, the most frequently detected compound (43 percent of samples), may enter the hydrologic system from recharge of chlorinated water, direct releases 
Table 1. Maximum concentration, detection frequency, and maximum benchmark quotient for regulated and unregulated compounds detected in samples from 30 source-water wells of community water systems in the northern Tampa Bay area.

[MRL, minimum reporting level; USEPA, U.S. Environmental Protection Agency; MCL, Maximum Contaminant Level; HBSL, Health-Based Screening Level; BQmax, maximum benchmark quotient = ratio of maximum compound concentration to MCL or HBSL value; DEET, N,N,-diethyl-meta-toluamide; E, estimated value; $\mu \mathrm{g} / \mathrm{L}$, micrograms per liter; <, less than; NA, not applicable; --, not available. A regulated compound is a compound for which Federal and (or) State drinking-water standards have been established; an unregulated compound is a compound for which no Federal and (or) State drinking-water standards have been established]

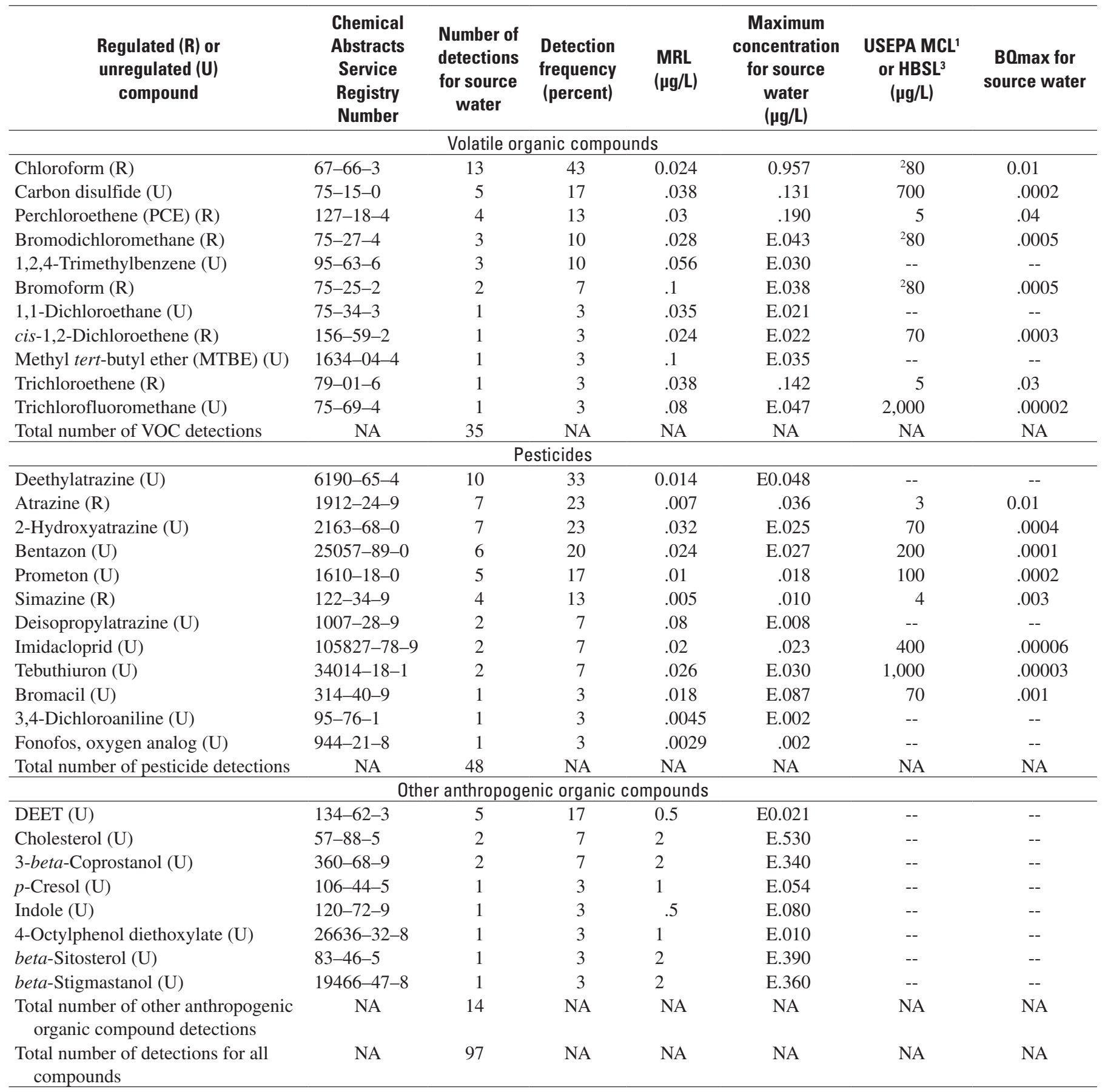

${ }^{1}$ U.S. Environmental Protection Agency (2003, 2004).

${ }^{2} \mathrm{MCL}$ is for total trihalomethanes.

${ }^{3}$ Denotes HBSL (Toccalino and others, 2006a). 

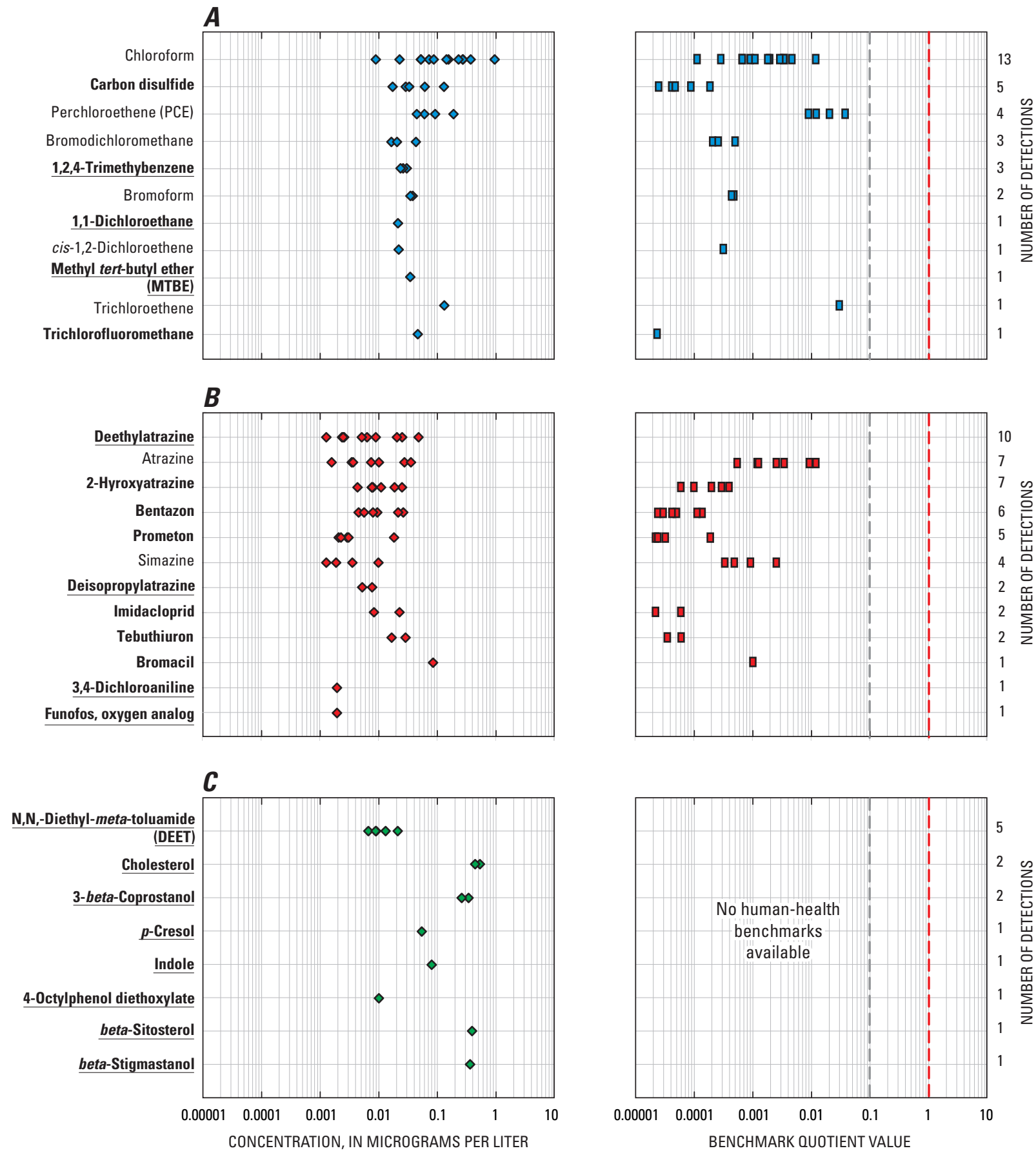

\section{EXPLANATION}

Benchmark quotient value of $0.1-$ Values equal to or greater than this line may warrant inclusion of the compound in a low-concentration, trends-monitoring program

| Benchmark quotient value of 1.0-

I Values greater than this line

I indicate concentrations of

potential human-health concern

[Bold type indicates an unregulated compound; underlined indicates the unregulated compound does not have an HBSL; benchmark quotient value is the ratio of the detected concentration of a particular compound to its

Maximum Contaminant Level (regulated compounds) or Health-Based Screening Level (unregulated compounds)]

Figure 6. Concentrations, number of detections, and benchmark quotient values for $(A)$ volatile organic compounds, $(B)$ pesticides, and $(C)$ other anthropogenic organic compounds from 30 source-water wells during phase 1. 
(air emissions, discharges to surface water, underground injections, and releases to land), dehalogenation of carbon tetrachloride, and a variety of natural sources (Ivahnenko and Barbash, 2004). Chloroform is one of the four disinfection by-products (DBPs; bromodichloromethane, bromoform, chloroform, and dibromochloromethane) produced in the highest concentrations during the chlorination of drinking water and wastewater. Detection of chloroform in ground water along with associated DBPs provides a means for distinguishing between the input of chlorinated water to the hydrologic system and the input of other chloroform sources to the environment (Ivahnenko and Barbash, 2004).

The frequent detection of chloroform in the study area may be from several sources such as chlorinated or reclaimed water to irrigate lawns and gardens; leakage from distribution lines for treated water and wastewater; spas; pools; and leachate from septic-system drainfields (Thiros, 2000). Several lines of evidence indicate that chloroform in the study area is associated with the by-product of chlorination and not from natural sources. For example, the associated DBPs (bromodichloromethane and bromoform) also were detected in the source water, and chloroform was only found in residential and commercial areas and not detected in undeveloped areas (as discussed further in subsequent sections). Other frequently detected VOCs include the solvents carbon disulfide (also occurs naturally) and PCE (also known as tetrachloroethene or tetrachloroethylene), which is primarily used as a dry-cleaning agent.

Concentrations for VOCs detected in the source water were low (fig. 6A). Of the 11 VOCs detected, human-health benchmarks were available for 8 compounds. BQmax values for these 8 VOCs typically were several orders of magnitude below 1 and none were greater than 0.1 (table 1 ). This indicates that the concentrations of these VOCs are unlikely to be of potential human-health concern or warranted to be included in a low-concentration, trends-monitoring program. An HBSL was not available for 1,2,4-trimethylbenzene because human-health toxicity information was not available; however, additional monitoring of this VOC may be warranted on the basis of its frequent occurrence (10 percent of samples) to better understand its spatial and temporal distribution as well as its sources, transport, and fate.

\section{Pesticides}

Twelve pesticide compounds were detected in the source water (table 1, fig. 6B). Although the number of individual pesticides detected (12) was roughly about the same as for VOCs (11), pesticides were detected more frequently in comparison to VOCs (48 pesticide detections compared to 35 VOC detections). However, the analytical methods allow pesticides to be detected at lower concentrations than VOCs (Appendixes 1 and 2).

Of the 48 pesticide detections, most (54 percent) were derived from atrazine ( 7 detections) and its breakdown products deethylatrazine (10 detections), 2-hydroxyatrazine (7 detections), and deisopropylatrazine (2 detections). Several reasons exist for the high detection frequency for atrazine and deethylatrazine including high mobility in sandy soils, widespread use, and persistence in ground water (Kruger and others, 1995; Barbash and others, 1999). The half-life for atrazine in soils can be more than 100 days and in ground water, atrazine and deethylatrazine can persist for almost 6 years and more than 25 years, respectively (Denver and Sandstrom, 1991; Gaus, 2000).

Concentrations of pesticides detected in the source water were low (fig. 6B). Of the 12 pesticides detected, human-health benchmarks were available for 8 of these compounds. BQmax values for these 8 pesticides typically were several orders of magnitude below 1 and none were greater than 0.1 (table 1). Human-health benchmarks were not available for deethylatrazine and, as such, additional monitoring may be warranted on the basis of its frequent occurrence (33 percent of samples).

\section{Other Anthropogenic Organic Compounds}

Eight OAOCs were detected in the source-water samples, and concentrations were low (table 1, fig. 6C). Of the eight OAOCs detected, none had human-health benchmarks to compare with measured concentrations.

\section{Effects of Hydrogeology on Ground-Water Quality}

Fifteen wells were sampled in this study in both the unconfined and semiconfined areas of the Upper Floridan aquifer due to the importance of each area as a source of drinking-water supply (fig. 4). Water-quality results obtained from the unconfined and semiconfined areas were compared to characterize the differences, or lack thereof, between these two types of hydrogeologic settings.

Of 31 AOCs detected a total of 97 times (table 1), almost twice as many detections occurred in the unconfined areas (62) as in the semiconfined areas of the Upper Floridan aquifer (35) (fig. 7). There were 27 detections of VOCs in the unconfined areas and 8 detections of VOCs in the semiconfined areas of the Upper Floridan aquifer (fig. 7). Sixteen of the 27 VOCs detected were DBPs. This included 11 detections of chloroform, 3 of bromodichloromethane, and 2 of bromoform. Only two detections of chloroform occurred in semiconfined areas. The higher detection frequency of DBPs in unconfined areas than in semiconfined areas may be related to less clay confinement where unconfined, which may increase the potential for transport of DBPs, or may be due to a greater population density around the wells in the unconfined areas (as described in the following section).

Pesticide detections also were more frequent in unconfined areas (34) than in semiconfined areas (14) of the Upper Floridan aquifer (fig. 7). Atrazine and the 


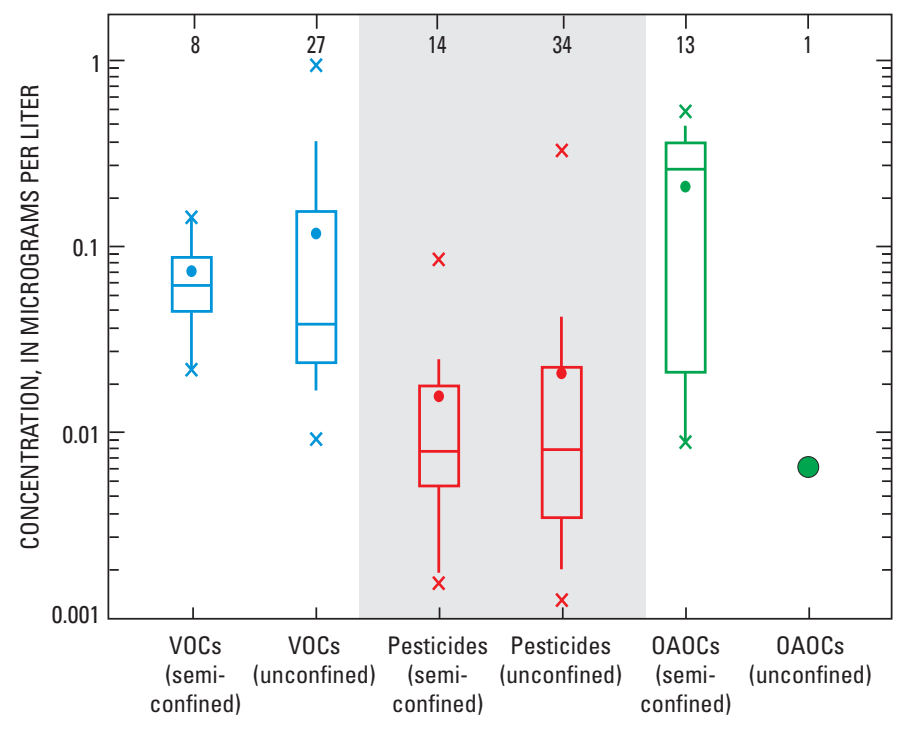

EXPLANATION

8 Number of observations

$\times$ Outlier data value more than 1.5 times the interquartile range outside the quartile

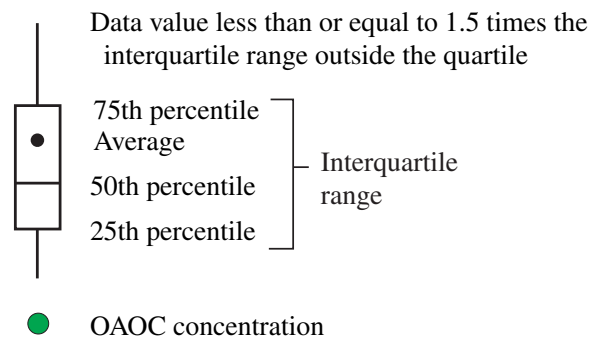

[VOCs, volatile organic compounds; OAOCs, other anthropogenic organic compounds]

Figure 7. Concentrations of all detected anthropogenic organic compounds in source water from semiconfined and unconfined areas of the Upper Floridan aquifer during phase 1.

breakdown products deethylatrazine, 2-hydroxyatrazine, and deisopropylatrazine were detected a total of 19 times in unconfined areas compared to 7 times in semiconfined areas. Deethylatrazine, which was detected 8 times in the unconfined areas and only 2 times in the semiconfined areas, is the most mobile of the atrazine breakdown products and is more mobile in sandy soils than in clayey soils (Kruger and others, 1995). Other pesticide compounds were cumulatively detected 15 times in unconfined areas and 7 times in semiconfined areas.

In contrast to what was observed for VOCs and pesticides, OAOCs were detected more frequently in semiconfined areas than in unconfined areas (fig. 7). One OAOC was detected in one well sample from the unconfined areas, and 13 OAOCs were detected in semiconfined areas. Little is known about the transport and fate of these compounds in ground water, but many of the detections in this study appear to be more site specific than regionally widespread. Nine of the 14 detections of OAOCs occurred in source-water samples from two wells in the semiconfined area of the Upper Floridan aquifer; 6 OAOCs in one well sample and 3 OAOCs in the other well sample. These wells were located near facilities that utilize septic systems. DEET was detected in 4 well samples from semiconfined areas and 1 well sample from unconfined areas.

On the basis of these results, hydrogeology plays an important role in the detection of AOCs in CWS wells, especially for VOCs and pesticides. These compounds are used extensively and have a potential to reach ground water by direct application to the land surface or through a variety of sources from the primary use of the product. OAOCs, on the other hand, may have more specific sources and (or) pathways to enter the environment, such as by wastewater from a wastewater-treatment plant and septic tank effluent. As described in more detail in the following section, the population density surrounding wells in unconfined areas was twice the population surrounding wells in semiconfined areas, thereby magnifying the susceptibility of the ground-water quality in the unconfined areas. However, the more populous areas surrounding the wells in unconfined areas (figs. 2 and 4) typically use municipal sewer systems, and the less populous areas surrounding the wells in semiconfined areas use more septic systems. This may result in a higher potential for OAOC occurrence in the areas using septic systems and, in part, may help explain why OAOCs were detected more frequently in the less populated, semiconfined areas.

\section{Effects of Land Use and Population Density on Ground-Water Quality}

GIS land-use coverages were evaluated to characterize the effects of land use on ground-water quality. For this analysis, land use was categorized within a 500-meter (m) $(1,640-\mathrm{ft})$ radius for each sampled well. Land use surrounding the 30 wells varied and was categorized as follows: residential (37 percent); open land and recreational (26 percent); wetlands and surface water (18 percent); agricultural (pasture and tree plantations, 11 percent); commercial, industrial, and transportation (7 percent); and agricultural (nurseries and farms, 1 percent) (fig. 2). Population also was determined within a 500-m radius for each well. Satellite land-use imagery was used to determine the population surrounding each well by assigning 2.5 residents per household.

The population within a 500-m radius of the CWS well compared to the number of detected compounds for each well is shown in figure 8A. At least one AOC was detected in 22 of the 30 source-water samples. In general, the number of compounds detected in each well sample decreased as the population surrounding each well decreased. AOCs were not detected in 8 of the well samples, 7 of which were from well fields where residential and commercial development is prohibited. 

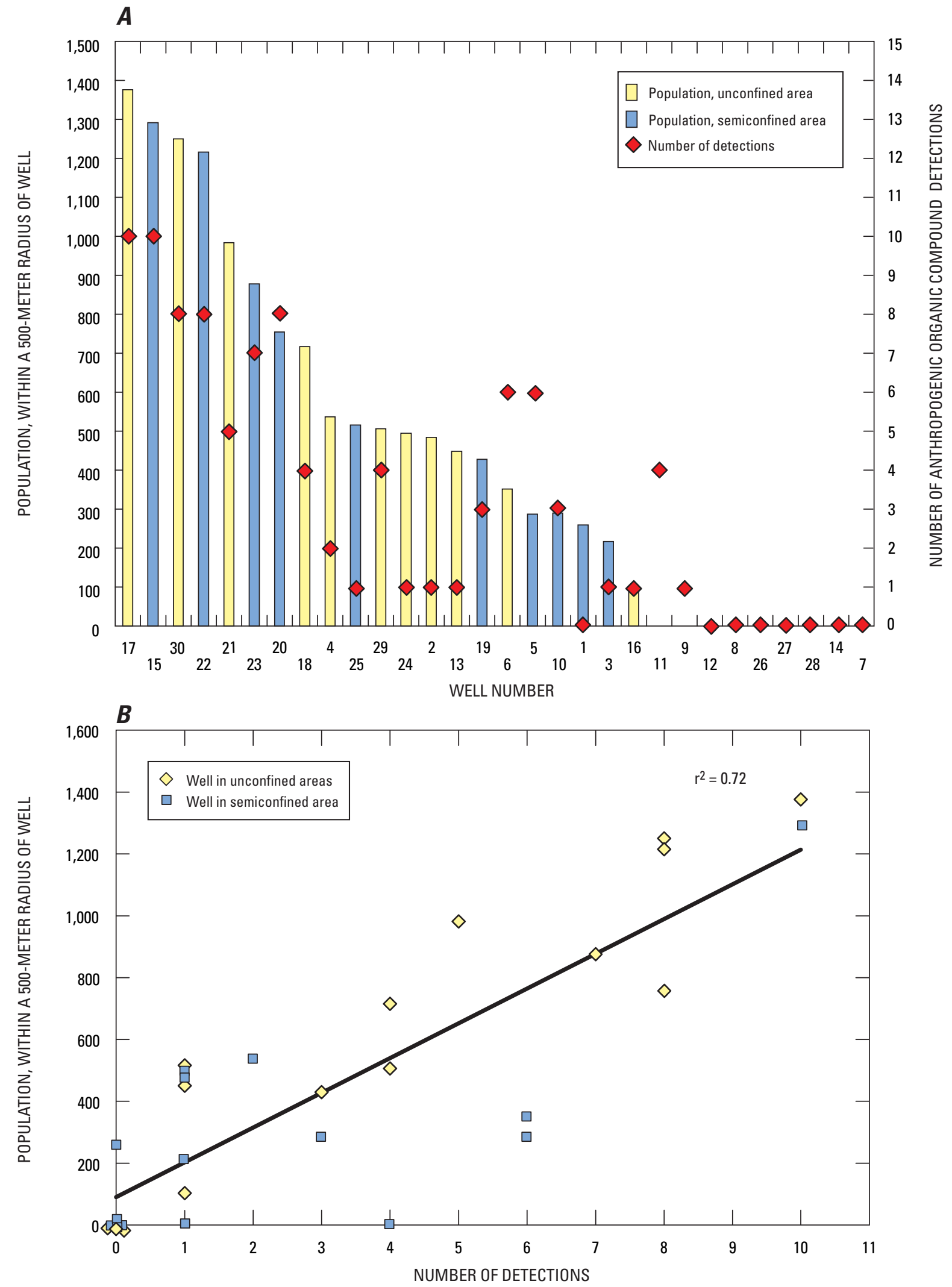

Figure 8. Number of anthropogenic organic compound detections in source-water samples collected during phase 1 in $(A)$ comparison to population surrounding source-water wells in unconfined or semiconfined areas, and $(B)$ statistical relations with population. 
Linear and multiple linear regression analyses were used to mathematically relate the number of anthropogenic compounds detected in the 30 source-water samples to land use, population, hydrogeology, well depth, and well screen depth. With a regression significant to an alpha of 0.05 (95-percent confidence interval), population was the parameter that provided the best regression estimate $\left(r^{2}=0.72\right.$; fig. $8 B$ ). As the population surrounding the well increases, the number of AOCs increased. Relations improved $\left(r^{2}=0.82\right)$ when OAOCs were removed from the analysis. OAOCs, as described previously, were detected in areas where the population was low and relied on the use of septic systems.

Chloroform detections and concentrations were highest beneath areas where residential land use was greater than 60 percent and 73 percent, respectively. Pesticides were detected in areas where the residential land use was greater than 68 percent, except deethylatrazine, where two detections occurred in a mixed land-use area.

\section{Comparison of Source-Water Results to Results from Other Studies}

Results from the source-water samples from the $30 \mathrm{CWS}$ wells monitored in this study were compared to results from four locally conducted studies that characterized VOCs, pesticides, and (or) OAOCs in the Upper Floridan aquifer in the northern Tampa Bay area or in the Biscayne aquifer in
Miami-Dade, Broward, and Palm Beach Counties (table 2). These studies were conducted by USGS personnel using the same field and analytical techniques as were used in the SWQA study. Three of the five studies (studies A, B, and C) listed in table 2 were conducted as part of the NAWQA Program. As such, these studies incorporated a "nested" design for sampling that allows information to be applied at several spatial scales in the same hydrologic unit because all samples were collected within the confines of one geographic boundary. Although not conducted by the NAWQA Program, studies D and E provide valuable information for comparison to different aquifers and (or) types of wells in the area. However, differences in compounds monitored for this SWQA study (study A) and those compounds monitored for other studies do not allow for a direct comparison among all five studies.

For study B, 34 shallow monitoring wells in urban areas in the northern Tampa Bay area were sampled during 2002 as part of the NAWQA Program's urban land-use study (ULUS) component that monitors shallow ground water under residential and commercial areas. Sixty domestic wells in the Upper Floridan aquifer were sampled as part of the NAWQA Program's major aquifer study (MAS) effort (study C), which was a study designed to broadly characterize the quality of water representing current or future sources of drinking water. For study D, 30 public-supply wells in the Biscayne aquifer were sampled in Miami-Dade, Broward, and Palm Beach Counties, Florida. For study E, 38 wells of varying types were

Table 2. Summary of locally conducted ground-water quality studies that evaluated the occurrence of volatile organic compounds, pesticides, and (or) other anthropogenic organic compounds.

[NAWQA, National Water-Quality Assessment; GAFL, Georgia-Florida Coastal Plain; GW, ground water; SWQA, Source Water-Quality Assessment; VOCs, volatile organic compounds; OAOCs, other anthropogenic organic compounds; ULUS, urban land-use study; MAS, major aquifer study]

\begin{tabular}{|c|c|c|c|c|c|c|}
\hline $\begin{array}{c}\text { Study } \\
\text { identifier }\end{array}$ & $\begin{array}{l}\text { Ground-water } \\
\text { quality study }\end{array}$ & $\begin{array}{l}\text { Comparison } \\
\text { data }\end{array}$ & Types of wells sampled & $\begin{array}{l}\text { Number } \\
\text { of wells } \\
\text { sampled }\end{array}$ & $\begin{array}{l}\text { Median } \\
\text { well depth } \\
\text { (feet) }\end{array}$ & $\begin{array}{l}\text { Sampling } \\
\text { frequency and } \\
\text { period }\end{array}$ \\
\hline A & $\begin{array}{l}\text { NAWQA GAFL } \\
\text { GW SWQA }{ }^{1}\end{array}$ & $\begin{array}{l}\text { VOCs, } \\
\text { pesticides, } \\
\text { and OAOCs }\end{array}$ & $\begin{array}{l}\text { Existing large capacity public-supply wells } \\
\text { in the unconfined and semi-confined areas } \\
\text { of Upper Floridan aquifer in the northern } \\
\text { Tampa Bay area, Florida }\end{array}$ & 30 & 563 & Once in 2002. \\
\hline B & NAWQA ULUS² & $\begin{array}{l}\text { VOCs and } \\
\text { pesticides }\end{array}$ & $\begin{array}{l}\text { Shallow monitoring wells in the northern } \\
\text { Tampa Bay area, Florida }\end{array}$ & 34 & 42 & Once in 2002. \\
\hline $\mathrm{C}$ & NAWQA MAS² & $\begin{array}{l}\text { VOCs and } \\
\text { pesticides }\end{array}$ & $\begin{array}{l}\text { Domestic wells in the Upper Floridan aquifer } \\
\text { in central Florida to southern Georgia }\end{array}$ & 60 & 83 & Once in 2002. \\
\hline $\mathrm{D}$ & $\begin{array}{l}\text { Bradner and } \\
\text { others }(2005)\end{array}$ & $\begin{array}{l}\text { VOCs and } \\
\text { pesticides }\end{array}$ & $\begin{array}{l}\text { Public-supply wells in the Biscayne aquifer } \\
\text { in Miami-Dade, Broward, and Palm Beach } \\
\text { Counties, Florida }\end{array}$ & 30 & 105 & $\begin{array}{c}\text { Once during } \\
\text { 1996-98. }\end{array}$ \\
\hline $\mathrm{E}$ & Phelps (2004) & OAOCs & $\begin{array}{l}\text { Domestic, monitoring, and drinking-water } \\
\text { wells and three springs in the Upper } \\
\text { Floridan aquifer in the Silver Springs } \\
\text { Basin, Florida }\end{array}$ & 38 & 107 & $\begin{array}{l}\text { Once during } \\
2001-02 \text {. }\end{array}$ \\
\hline
\end{tabular}

${ }^{1}$ Topic of this report.

${ }^{2}$ W.S. McBride, U.S. Geological Survey, written commun., 2005. 
sampled in areas thought to be susceptible to contamination from human or animal waste. The comparisons conducted herein are only intended to provide initial and general insight on how representative other studies may, or may not be, of source water used by CWSs and to set the stage for future, more detailed comparisons.

\section{Volatile Organic Compounds}

Eleven VOCs were detected in samples from CWS wells monitored in the northern Tampa Bay area as part of this SWQA (table 1, study A in Appendix 5). A total of 15 VOCs were detected in each of the locally nested studies $\mathrm{B}$ and C. Many of these VOCs, however, were detected in only one sample. Five of the VOCs detected once in study A (1,1-dichloroethane, trichlorofluoromethane, cis-1,2-dichloroethene, trichloroethene, and MTBE) and bromoform (which was detected in only 2 samples) also were detected infrequently (less than about 5 percent) in studies B and $\mathrm{C}$.

Chloroform, carbon disulfide, and PCE were the first, second, and third most frequently detected VOCs in this SWQA, respectively. With the exception of carbon disulfide in study D, these three compounds also were among the top five most frequently detected VOCs in each of the comparison studies. Although not detected in this SWQA, toluene was the second most frequently detected VOC in nested studies B (detected in 18 percent of samples) and C (detected in 25 percent of samples) of the Upper Floridan aquifer.

Results for study D, for which 30 public-supply wells in the Biscayne aquifer were sampled, showed that proportionately more VOCs were detected from these well samples in comparison to any other locally conducted study (Appendix 5). This may be explained, in part, by the high permeability of the sand and limestone sediments and shallow water table of the Biscayne aquifer, in comparison to the Upper Floridan aquifer, which makes these ground waters more vulnerable to contamination by human activities. The VOCs that occurred infrequently in studies A, B, and C occurred in as many as 40 percent of samples in study D. The VOCs cis-1,2-dichloroethene and MTBE occurred in 40 and 30 percent, respectively, of public-supply well samples from the Biscayne aquifer, and 1,1-dichloroethane and bromoform were detected in 13 and 10 percent of these samples, respectively.

These general comparisons indicate that VOCs that occurred relatively infrequently in other studies of the Upper Floridan aquifer also tend to be found infrequently in source water of large CWSs in the area. Similarly, those VOCs that occurred most frequently in other studies also occurred relatively frequently (on a ranking basis) in source water; particularly chloroform, carbon disulfide, and PCE. Thus, the results of other locally conducted studies described herein tend to be similar to source-water results from CWSs monitored in this SWQA. However, the larger number and frequency of detection of VOCs detected in the Biscayne aquifer (study D) in comparison to studies $\mathrm{A}, \mathrm{B}$, and $\mathrm{C}$ do document their occurrence and, thus, potential to be present in other source waters in the area.

\section{Pesticides}

Twelve pesticides were detected in CWS wells monitored in the northern Tampa Bay area as part of this SWQA (table 1, study A in Appendix 6). Three of these pesticides (bromacil, fonofos, oxygen analog, and 3,4-dichloroanaline) were detected in only one sample and three pesticides (deisopropylatrazine, imidacloprid, and tebuthiuron) were detected in only two samples. Each of these five pesticides also were detected relatively infrequently (in less than 13 percent of samples) or not analyzed in locally nested studies B and C.

The five most frequently detected pesticides in this SWQA were deethylatrazine, atrazine, 2-hydroxyatrazine, bentazon, and prometon. Each of these pesticides also was typically among the top six most frequently detected pesticides in each of the comparison studies (if analyzed). Interestingly, atrazine and its breakdown products, deethylatrazine and 2-hydroxyatrazine, were detected more frequently in this SWQA (in 23 to 33 percent of samples) than in studies B and $\mathrm{C}$ (equal to or less than 3 percent of samples). However, atrazine and deethylatrazine were detected more frequently in study D, occurring in 73 and 63 percent of samples, respectively.

As was observed for VOCs, proportionately more pesticides were detected in samples from the Biscayne aquifer (study D) in comparison to studies A, B, and C. Tebuthiuron was detected in 77 percent of public-supply well samples (study D), and other pesticides detected frequently in study $\mathrm{D}$ but detected infrequently or not detected in studies $\mathrm{A}, \mathrm{B}$, and $C$ include diuron (53 percent), fenuron (30 percent), and metolachlor (27 percent).

These general comparisons indicate that pesticides, especially atrazine and its breakdown products (deethylatrazine and 2-hydroxyatrazine), occur more frequently in the source water monitored as part of this SWQA in comparison to studies B and C. However, the large difference in both the number and frequency of detection of pesticides detected in the Biscayne aquifer (study D) documents their occurrence and potential to be present in other source waters in the area.

\section{Other Anthropogenic Organic Compounds}

SWQAs are the only component of the NAWQA Program to monitor OAOCs, therefore it is not possible to compare SWQA results with locally nested studies of the Upper Floridan aquifer. However, one other study (study E) was conducted by the USGS Florida Water Science Center (table 1, Appendix 7). Because study E was conducted in areas thought to be susceptible to wastewater contamination, it seems likely 
that a greater number of OAOCs would be detected more frequently in study E in comparison to this SWQA. This was found to be true (Appendix 7). In contrast to the comparison of VOCs and pesticides to other studies, comparison of OAOC results to other studies is difficult due to the relative newness of analytical methods for these compounds, which results in fewer completed studies.

Eight OAOCs were detected in samples from CWS wells monitored as part of this SWQA. Five of these compounds were detected in only one SWQA sample, and two of these compounds were detected in only two samples. Although OAOCs were detected infrequently, these results indicate that some OAOCs have sufficient persistence and mobility to be transported to CWS wells at detectable quantities. DEET occurred most frequently (5 samples, 17 percent). Other studies have found DEET in rivers, streams, ground water, springs, and seawater (Weigel and others, 2002; Sandstrom and others, 2005); it occurred most frequently in study E (30 of the 38 samples; 79 percent) (Appendix 7). Toxicological data do not show DEET to be carcinogenic, significantly developmentally toxic, or mutagenic (U.S. Environmental Protection Agency, 1998).

In general, most (7 of 8) of the OAOCs detected in this SWQA also were detected in study E. Ten additional OAOCs occurred in the Upper Floridan aquifer in study E that were not detected in CWS wells sampled for this SWQA. The similarities between those OAOCs detected in study E and those detected as part of this SWQA indicate that these compounds are sometimes present in source water. Additional monitoring of these compounds to further characterize their occurrence in source water and finished water is needed to more fully understand their temporal patterns and potential sources, fate, and transport.

\section{Anthropogenic Organic Compounds in Ground Water and Finished Water during Phase 2}

Eleven of the original $30 \mathrm{CWS}$ wells that had the highest number of detections of AOCs were resampled during phase 2 of this SWQA along with the associated finished water during August and September 2004. For the 11 finished-water samples, 5 were blended with ground water from other CWS wells, and 6 were not blended. Because these CWSs were sampled only for those AOCs that occurred most frequently during phase 1 , not all pairs of CWS wells and associated finished water were sampled for the same AOCs. That is, 10 pairs of source water and the associated finished water were analyzed for VOCs, 6 for pesticides, and 2 for OAOCs. The process used to select CWS wells was biased to those compounds that occurred most frequently, and because this process resulted in a small number of samples (especially for OAOCs), characterization of the overall occurrence of these compounds in source water and finished water is not feasible. Thus, a general comparison of these compounds in source water and finished water is presented.

For interpretive purposes, select finished-water results were separated as blended and non-blended waters. This differentiation provides additional insight about the effect of blending on finished-water quality and allows for examination of occurrence findings separately for CWSs that do not blend with those that do blend. Concentrations of each AOC detected in source water and the associated blended or non-blended finished water are presented in Appendix 8 and number of detections, maximum concentrations, and BQmax values are presented in table 3 .

Overall, 35 AOCs were detected in either source water or finished water and more compounds were detected in finished water than in source water. Specifically, 22 individual AOCs (8 VOCs, 10 pesticides, and 4 OAOCs) were detected in source water and 27 (14 VOCs, 8 pesticides, and 5 OAOCs) were detected in finished water. The total number of detections also were greater in the finished water (80) than in the source water (49); however, this was largely due to the creation of disinfection by-products in the finished water. Excluding DBPs, about the same number of total detections was observed in source water (40) as in finished water (44). Samples generally contained a mixture of compounds with an average of 4 compounds in source water and 7 compounds in finished water.

\section{Volatile Organic Compounds}

Samples from $10 \mathrm{CWS}$ wells and the associated finished water were analyzed for VOCs. Four of the finished-water samples represented water blended with ground water from other CWS wells prior to treatment, and six were not blended. A total of 18 VOCs were detected in either the source water or the finished water. Specifically, 8 and 14 VOCs were detected in the source- and finished-water samples, respectively (table 3). However, four of the VOCs detected in finished water were DBPs. Chloroform was detected in 8 source-water and in all 10 finished-water samples. Other DBPs typically were not detected in the source water but were detected in all or most of the finished-water samples, including bromodichloromethane (10 of 10 samples), dibromochloromethane (9 of 10 samples), and bromoform (8 of 10 samples).

Four VOCs (acetone, methyl ethyl ketone, tetrahydrofuran, chloroethane, and trichloroethene) were detected in only one source-water sample, albeit at fairly large concentrations (as much as 1,140 $\mu \mathrm{g} / \mathrm{L}$ ), but were not detected in the finished water (table 3 ). Ten additional VOCs were not detected in the source water but were detected in at least one finished-water sample. Five of these 11 VOCs (methyl isobutyl ketone, ethylbenzene, $o$-xylene, $m$ - and $p$-xylene, and chloromethane) occurred in non-blended finished water of the same well (CWS well 29), whereas carbon tetrachloride and toluene each occurred in blended finished water of different 
wells (Appendix 8). With the exception of the DBPs, the detection of compounds in the finished water and not in the source water may be due to several reasons. For example, compounds detected in the non-blended finished water of well 29 may have been introduced to the water from a CWS pump as a result of normal lubrication and service, or from pipe gaskets or other materials used between the sourceand finished-water sample location. The detection of other compounds in the blended finished water may be due to their presence in other source waters blended with the source water monitored as part of this study, which in turn composes the sampled finished water.

Concentrations of detected VOCs ranged from E0.033 to $1,140 \mu \mathrm{g} / \mathrm{L}$ in the source water and from E0.018 to $36.3 \mu \mathrm{g} / \mathrm{L}$ in the finished water. Concentrations of the four DBPs were higher in finished water than in source water, and concentrations tended to be greater in blended finished water than in non-blended finished water (fig. 9A, Appendix 8).

Concentrations of 15 of the 18 VOCs detected in either source water or finished water typically were well below their human-health benchmark and, as such, BQmax values were typically several orders of magnitude below 1 (table 3 , fig. 9B). This indicates that none of these 15 individual VOCs were detected at concentrations of potential human-health concern.

$\mathrm{BQmax}$ values for methyl ethyl ketone detected in source water and BQmax values for chloroform, dibromochloromethane, and carbon tetrachloride detected in finished water were greater than or equal to 0.1. It should be noted, however, that the MCL used to calculate BQmax values for chloroform and dibromochloromethane is intended for the summation of concentrations of these two compounds plus the other DBPs bromoform and bromodichloromethane. Although not in table 3, summing all maximum concentrations of these four DBPs in source water and finished water results in BQmax values equal to 0.012 and 0.72 , respectively, further indicating concentrations were not greater than the MCL. Disinfection by-products already are monitored routinely by CWSs. Methyl ethyl ketone was detected only in one source-water sample, so additional monitoring may not be necessary. However, carbon tetrachloride, which was detected in 3 of 10 finished-water samples and at concentrations within 10 percent of its human-health benchmark may warrant inclusion in a low-concentration, trends-monitoring program to better understand temporal and spatial patterns, and its potential sources, fate, and transport. HBSLs were not available for two detected unregulated VOCs (methyl isobutyl ketone and tetrahydrofuran) because human-health toxicity information was not available.

These results indicate that monitoring VOCs in source water does not necessarily characterize the occurrence of VOCs in finished water. This is especially true for DBPs that are formed as a result of disinfection. In addition, 14 of the 18 (12 of 16 if DBPs are excluded) VOCs were detected in either the source water or finished water, but not both. These differences may be due largely to blending. That is, VOCs present in source water but not the finished water may have been diluted to undetectable concentrations in the finished water by blending with other source water that didn't contain those VOCs. Similarly, VOCs present in the finished water but not the source water sampled may have been present in the source water from other wells.

\section{Pesticides}

Samples from six CWS wells and associated finished water were analyzed for pesticides. Two of the finishedwater samples represented water blended with ground water from other CWS wells prior to treatment and four were not blended. A total of 10 individual pesticides were detected in either the source water or finished water, and all 10 of these pesticides were detected in at least one source-water sample. Eight pesticides were detected in finished-water samples (table 3). The most frequently detected compounds in both the source and the finished water were atrazine and its breakdown products 2-hydroxyatrazine and deethylatrazine. These compounds, if detected in source water, also generally were detected in the associated finished water, whether it was blended or not blended (Appendix 8). 2-Hydroxyatrazine was present in all 6 source-water and finished-water samples, whereas atrazine and deethylatrazine were each detected in 5 source-water and 5 finished-water samples (Appendix 8). It should be noted that 2-hydroxyatrazine, atrazine, and deethylatrazine also were among the most frequently detected pesticides in finished water from 12 community surface-water supply sites sampled across the Nation (Coupe and Blomquist, 2004). Bentazon also was detected frequently in the source water (5 of 6 source-water samples); however, it was only detected in 1 finished-water sample. Two pesticides, bromacil and deisopropylatrazine, were detected in 1 and 2 source-water samples, respectively, but were not detected in any finishedwater samples.

Concentrations of detected pesticides in source water and finished water were similar and low, ranging from E0.001 to E0.059 $\mu \mathrm{g} / \mathrm{L}$ in the source water and from E0.003 to E0.035 $\mu \mathrm{g} / \mathrm{L}$ in finished water (fig. 10, Appendix 8). Concentrations of 8 of the 10 pesticides detected were compared to human-health benchmarks, and BQmax values were about four orders of magnitude below 0.1. HBSLs were not available for deethylatrazine and deisopropylatrazine; however, their frequent occurrence in both source and finished water may warrant additional monitoring.

These results indicate that monitoring pesticides in source water may reflect the occurrence of pesticides in finished water, especially for atrazine and its breakdown products. However, the effect of blending makes it difficult to characterize how representative source water is of finished water because many pesticides were detected more frequently in source water than in finished water. More data are needed to better characterize the representative nature of pesticides in source water compared to finished water. 
Table 3. Maximum concentrations, detection frequency, and maximum benchmark quotient for regulated and unregulated compounds detected in samples collected during phase 2 from 11 source-water wells and the associated finished water of community water systems in the northern Tampa Bay area.

[MRL, minimum reporting level; USEPA, U.S. Environmental Protection Agency; MCL, Maximum Contamination Level; HBSL, Health-Based Screening Level; $\mu \mathrm{g} / \mathrm{L}$, micrograms per liter; BQmax, benchmark quotient $=$ ratio of maximum detected compound concentration to MCL or HBSL value; DEET, N,N,-diethyl-meta-toluamide; TCEP, tri(2-chloroethyl)phosphate; TCPP, tri(dichlorisopropyl)phosphate; E, estimated value; <, less than; --, not available. A regulated compound is a compound for which Federal and (or) State drinking-water standards have been established; an unregulated compound is a compound for which no Federal and (or) State drinking-water standards have been established]

\begin{tabular}{|c|c|c|c|c|c|c|c|c|c|c|}
\hline \multirow{2}{*}{$\begin{array}{l}\text { Regulated (R) or } \\
\text { unregulated }(U) \\
\text { compound }\end{array}$} & \multirow{2}{*}{$\begin{array}{c}\text { Chemical } \\
\text { Abstracts } \\
\text { Service } \\
\text { Registry } \\
\text { Number }\end{array}$} & \multirow{2}{*}{$\begin{array}{l}\text { Number of } \\
\text { samples } \\
\text { collected }\end{array}$} & \multicolumn{2}{|c|}{ Number of detections } & \multirow{2}{*}{$\begin{array}{c}\text { MRL } \\
(\mu \mathrm{g} / \mathrm{L})\end{array}$} & \multicolumn{2}{|c|}{$\begin{array}{l}\text { Maximum concentration } \\
(\mu \mathrm{g} / \mathrm{L})\end{array}$} & \multirow{2}{*}{$\begin{array}{l}\text { USEPA } \\
\text { MCL' or } \\
\mathrm{HBSL}^{3} \\
(\mu \mathrm{g} / \mathrm{L})\end{array}$} & \multirow{2}{*}{$\begin{array}{l}\text { BOmax for } \\
\text { source } \\
\text { water }\end{array}$} & \multirow{2}{*}{$\begin{array}{c}\text { BOmax } \\
\text { for finished } \\
\text { water }\end{array}$} \\
\hline & & & $\begin{array}{c}\text { Source } \\
\text { water }\end{array}$ & $\begin{array}{c}\text { Finished } \\
\text { water }\end{array}$ & & $\begin{array}{c}\text { Source } \\
\text { water }\end{array}$ & $\begin{array}{c}\text { Finished } \\
\text { water }\end{array}$ & & & \\
\hline \multicolumn{11}{|c|}{ Volatile organic compounds } \\
\hline Bromodichloromethane (R) & $75-27-4$ & 10 & 1 & 10 & 0.028 & E0.040 & 7.48 & ${ }^{2} 80$ & 0.0005 & 0.09 \\
\hline Carbon disulfide (U) & $75-15-0$ & 10 & 1 & 1 & .038 & .116 & E.040 & 700 & .0002 & .00006 \\
\hline Chloroform (R) & $67-66-3$ & 10 & 8 & 10 & .024 & .948 & 36.3 & 280 & .01 & .5 \\
\hline Perchloroethene (PCE) (R) & $127-18-4$ & 10 & 1 & 3 & .03 & E.033 & E.080 & 5 & .007 & .02 \\
\hline Bromoform (R) & $75-25-2$ & 10 & 0 & 8 & .1 & -- & 5.52 & ${ }^{2} 80$ & -- & .07 \\
\hline Carbon tetrachloride (R) & $56-23-5$ & 10 & 0 & 3 & .06 & -- & .500 & 5 & -- & .1 \\
\hline Chloromethane (U) & $74-87-3$ & 10 & 0 & 1 & .17 & -- & E.116 & 30 & -- & .004 \\
\hline Dibromochloromethane (R) & $124-48-1$ & 10 & 0 & 9 & .1 & -- & 7.95 & ${ }^{2} 80$ & -- & .1 \\
\hline Ethylbenzene (R) & $100-41-4$ & 10 & 0 & 1 & .03 & -- & .593 & 700 & -- & .0009 \\
\hline Methyl isobutyl ketone (U) & $108-10-1$ & 10 & 0 & 1 & .37 & -- & 3.30 & -- & -- & -- \\
\hline Methyl tert-butyl ether (MTBE) (U) & $1634-04-4$ & 10 & 0 & 1 & .1 & -- & E. 100 & -- & -- & -- \\
\hline Toluene (R) & $108-88-3$ & 10 & 0 & 1 & .02 & -- & E.020 & 1,000 & -- & .00002 \\
\hline$o$-Xylene (R) & $95-47-6$ & 10 & 0 & 1 & .038 & -- & 1.03 & ${ }^{4} 10,000$ & -- & .0001 \\
\hline$m$ - and $p$-Xylene $(\mathrm{R})$ & $108-38-3$ & 10 & 0 & 1 & .06 & -- & 2.26 & ${ }^{4} 10,000$ & -- & .0002 \\
\hline Acetone (U) & $67-64-1$ & 10 & 1 & 0 & 6 & 68.4 & -- & 6,000 & .01 & -- \\
\hline Methyl ethyl ketone (MEK) (U) & $78-93-3$ & 10 & 1 & 0 & 2 & 1,140 & -- & 4,000 & .3 & -- \\
\hline Tetrahydrofuran (U) & $109-99-9$ & 10 & 1 & 0 & 1.2 & 279 & -- & -- & -- & -- \\
\hline Trichloroethene (R) & $79-01-6$ & 10 & 1 & 0 & .038 & E.046 & -- & 5 & .009 & -- \\
\hline Total number of VOC detections & NA & NA & 15 & 51 & NA & NA & NA & NA & NA & NA \\
\hline \multicolumn{11}{|c|}{ Pesticides } \\
\hline Atrazine (R) & 1912-24-9 & 6 & 5 & 5 & 0.007 & 0.023 & 0.012 & 3 & 0.008 & 0.003 \\
\hline Bentazon (U) & $25057-89-0$ & 6 & 5 & 1 & .024 & E.057 & E.035 & 200 & .0003 & .0002 \\
\hline Deethylatrazine (U) & $6190-65-4$ & 6 & 5 & 5 & .014 & E.025 & E.020 & -- & -- & -- \\
\hline 2-Hydroxyatrazine (U) & $2163-68-0$ & 6 & 6 & 6 & .032 & .029 & E.013 & 70 & .0004 & .0001 \\
\hline
\end{tabular}


Table 3. Maximum concentrations, detection frequency, and maximum benchmark quotient for regulated and unregulated compounds detected in samples collected during phase 2 from 11 source-water wells and the associated finished water of community water systems in the northern Tampa Bay area.—Continued

[MRL, minimum reporting level; USEPA, U.S. Environmental Protection Agency; MCL, Maximum Contamination Level; HBSL, Health-Based Screening Level; $\mu$ g/L, micrograms per liter; BQmax, benchmark quotient $=$ ratio of maximum detected compound concentration to MCL or HBSL value; DEET, N,N,-diethyl-meta-toluamide; TCEP, tri(2-chloroethyl)phosphate; TCPP, tri(dichlorisopropyl)phosphate; E, estimated value; <, less than; --, not available. A regulated compound is a compound for which Federal and (or) State drinking-water standards have been established; an unregulated compound is a compound for which no Federal and (or) State drinking-water standards have been established]

\begin{tabular}{|c|c|c|c|c|c|c|c|c|c|c|}
\hline \multirow{2}{*}{$\begin{array}{l}\text { Regulated (R) or } \\
\text { unregulated }(U) \\
\text { compound }\end{array}$} & \multirow{2}{*}{$\begin{array}{c}\text { Chemical } \\
\text { Abstracts } \\
\text { Service } \\
\text { Registry } \\
\text { Number }\end{array}$} & \multirow{2}{*}{$\begin{array}{l}\text { Number of } \\
\text { samples } \\
\text { collected }\end{array}$} & \multicolumn{2}{|c|}{ Number of detections } & \multirow{2}{*}{$\begin{array}{c}\text { MRL } \\
(\mu \mathrm{g} / \mathrm{L})\end{array}$} & \multicolumn{2}{|c|}{$\begin{array}{l}\text { Maximum concentration } \\
(\mu \mathrm{g} / \mathrm{L})\end{array}$} & \multirow{2}{*}{$\begin{array}{l}\text { USEPA } \\
\text { MCL' or } \\
\mathrm{HBSL}^{3} \\
(\mu \mathrm{g} / \mathrm{L})\end{array}$} & \multirow{2}{*}{$\begin{array}{l}\text { BOmax for } \\
\text { source } \\
\text { water }\end{array}$} & \multirow{2}{*}{$\begin{array}{c}\text { B0max } \\
\text { for finished } \\
\text { water }\end{array}$} \\
\hline & & & $\begin{array}{c}\text { Source } \\
\text { water }\end{array}$ & $\begin{array}{c}\text { Finished } \\
\text { water }\end{array}$ & & $\begin{array}{c}\text { Source } \\
\text { water }\end{array}$ & $\begin{array}{c}\text { Finished } \\
\text { water }\end{array}$ & & & \\
\hline \multicolumn{11}{|c|}{ Pesticides-Continued } \\
\hline Imidacloprid (U) & $138261-41-3$ & 6 & 2 & 3 & 0.02 & 0.017 & 0.016 & 400 & 0.00005 & 0.00005 \\
\hline Prometon (U) & $1610-18-0$ & 6 & 1 & 1 & .01 & .009 & .010 & 100 & .00009 & .0001 \\
\hline Simazine (R) & $122-34-9$ & 6 & 1 & 1 & .005 & .010 & .007 & 4 & .003 & .002 \\
\hline Tebuthiuron (U) & $34014-18-1$ & 6 & 1 & 1 & .026 & .034 & .030 & 1,000 & .00003 & .00003 \\
\hline Bromacil (U) & $314-40-9$ & 6 & 1 & 0 & .018 & E.059 & -- & 70 & .0009 & -- \\
\hline Deisopropylatrazine (U) & $1007-28-9$ & 6 & 2 & 0 & .08 & E.004 & -- & -- & -- & -- \\
\hline Total number of pesticide detections & NA & NA & 29 & 23 & NA & NA & NA & NA & NA & NA \\
\hline \multicolumn{11}{|c|}{ Other anthropogenic organic compounds } \\
\hline Caffeine (U) & $58-08-2$ & 10 & 2 & 2 & 0.018 & E0.006 & E0.004 & -- & -- & -- \\
\hline $\operatorname{DEET}(\mathrm{U})$ & $134-62-3$ & 2 & 1 & 1 & .5 & E.08 & E.08 & -- & -- & -- \\
\hline Camphor (U) & $76-22-2$ & 2 & 0 & 1 & .5 & -- & E.013 & -- & -- & -- \\
\hline 1-Methylnaphthalene (U) & $90-12-0$ & 2 & 0 & 1 & .5 & -- & E.014 & -- & -- & -- \\
\hline 2-Methylnaphthalene (U) & $91-57-6$ & 2 & 0 & 1 & .5 & -- & E.025 & 30 & -- & 0.0008 \\
\hline TCEP (U) & $115-96-8$ & 2 & 1 & 0 & .5 & E. 110 & -- & -- & -- & -- \\
\hline TCPP (U) & $13674-87-8$ & 2 & 1 & 0 & .5 & E.081 & -- & -- & -- & -- \\
\hline $\begin{array}{l}\text { Total number of other anthropogenic } \\
\text { organic compound detections }\end{array}$ & NA & NA & 5 & 6 & NA & NA & NA & NA & NA & NA \\
\hline Total detections for all compounds & NA & NA & 49 & 80 & NA & NA & NA & NA & NA & NA \\
\hline
\end{tabular}

${ }^{1}$ U.S. Environmental Protection Agency (2003, 2004).

${ }^{2} \mathrm{MCL}$ is for total trihalomethanes.

${ }^{3}$ Denotes HBSL (Toccalino and others, 2006a).

${ }^{4} \mathrm{MCL}$ is for the sum of concentrations for mixed isomers of xylene. 

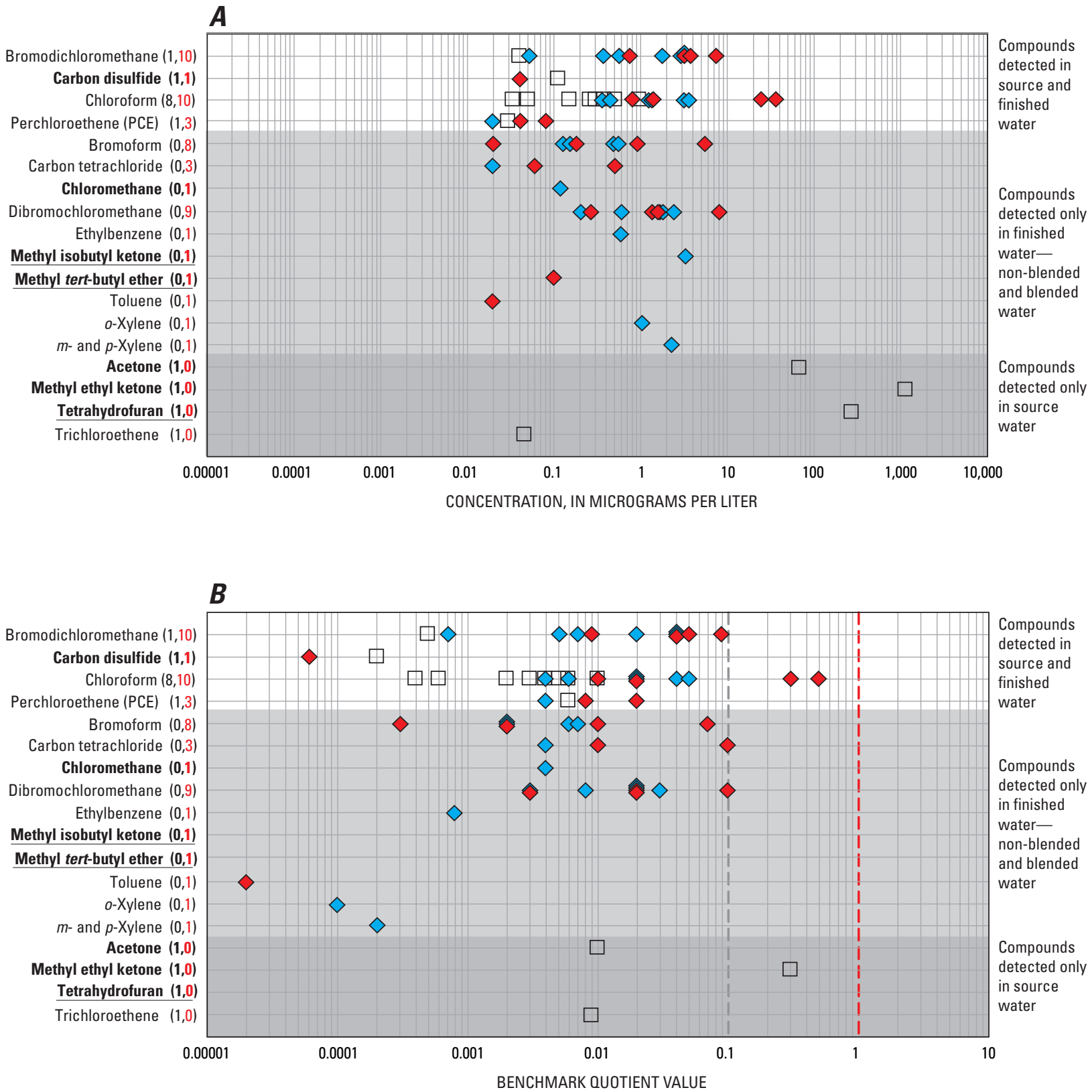

Chloroform $(8,10)$-Number of compounds detected for source water (8) and finished water (10); bold type indicates an unregulated compound; underlined indicates the unregulated compound does not have an HBSL

\section{EXPLANATION}

Benchmark quotient value of 0.1 Values equal to or greater than this line may warrant inclusion of the compound in a low-concentration, trends-monitoring program

| Benchmark quotient value of 1.0

Values greater than this line indicate concentrations of potential humanhealth concern

[Benchmark quotient value is the ratio of the detected concentration of a particular compound to its Maximum Contamination Level, MCL; or Health Based Screening Level, HBSL]

Figure 9. Detected volatile organic compounds in source water and associated finished water (non-blended and blended) during phase 2 showing $(A)$ concentrations and number of detections, and $(B)$ benchmark quotient values. 

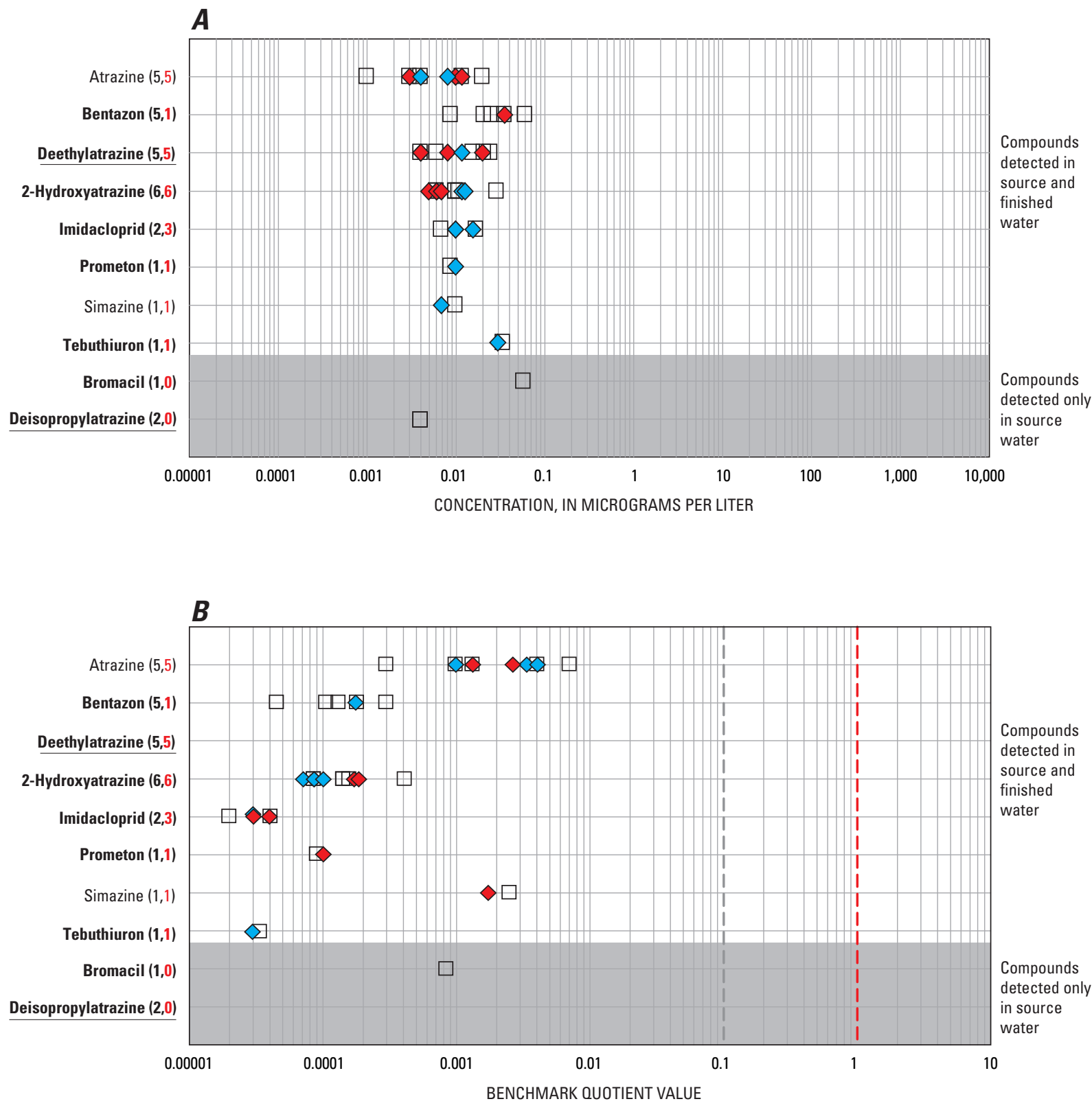

Atrazine $(5,5)$ - Number of compounds detected for source water (5) and finished water (5); bold type indicates an unregulated compound; underlined indicates the unregulated compound does not have an HBSL

\section{EXPLANATION}

Benchmark quotient value of $0.1-$ Values equal to or greater than this line may warrant inclusion of the compound in a low-concentration, trends-monitoring program

| Benchmark quotient value of 1.0

Values greater than this line indicate concentrations of potential humanhealth concern

[Benchmark quotient value is the ratio of the detected concentration of a particular compound to its Maximum Contamination Level, MCL; or Health Based Screening Level, HBSL]

Figure 10. Detected pesticides in source water and associated finished water (non-blended and blended) during phase 2 showing $(A)$ concentrations and number of detections, and $(B)$ benchmark quotient values. 


\section{Anthropogenic Organic Compounds in Ground and Finished Water in the Northern Tampa Bay Area, 2002-04}

\section{Other Anthropogenic Organic Compounds}

Samples from two CWS wells and associated finishedwater were analyzed for OAOCs. A total of seven OAOCs were detected in the source water and (or) finished water (table 3, Appendix 8). It is important to note, however, that caffeine is listed on table 3 and Appendix 8 as an OAOC. Caffeine was actually analyzed as part of other analytical methods; thus, it was monitored at more than two CWS wells. Four of the seven compounds were detected in the source water, and five were detected in the finished water. Of the seven OAOCs detected in either source or finished water, DEET was the only compound that also was detected during phase 1 sampling of source water. Caffeine was detected in both source-water samples and the associated finished water, and DEET was detected in source-water and the associated finished-water sample (table 3, Appendix 8). Three OAOCscamphor, 1-methylnaphthalene, and 2-methylnaphthalenewere not detected in source water but were detected in one finished-water sample. Because the finished water was blended, it is possible that the source of these compounds could be from water from other CWS wells containing these compounds that were not monitored for this SWQA. Two OAOCs-tri(2-chloroethyl)phosphate (TCEP) and tri(dichloroisopropyl)phosphate (TCPP) (flame retardants) were detected in source water but not in the finished water (table 2). It is possible that the compounds present in the source water could have been diluted to levels below detection when blended with waters from other CWS wells.

Concentrations of detected OAOCs were low, ranging from E0.006 to E0.11 $\mu \mathrm{g} / \mathrm{L}$ in the source water and from E0.004 to E0.075 $\mu \mathrm{g} / \mathrm{L}$ in the finished water (fig. 11, table 3, Appendix 8). Concentrations from only 1 of these 7 OAOCs (2-methylnaphthalene) were compared to human-health benchmarks, and BQmax values were 2 orders of magnitude below 0.1. HBSLs were not calculated for the remaining six detected unregulated OAOCs. However, additional monitoring of DEET may be warranted due to its frequent occurrence in source water (table 1) and presence in finished water (table 3, Appendix 8). More data are needed to determine how OAOCs in source water compare to finished water. However, these limited results indicate that OAOCs in source water are not necessarily representative of those in finished water because 5 of 7 OAOCs were detected in source water or finished water, but not both. 

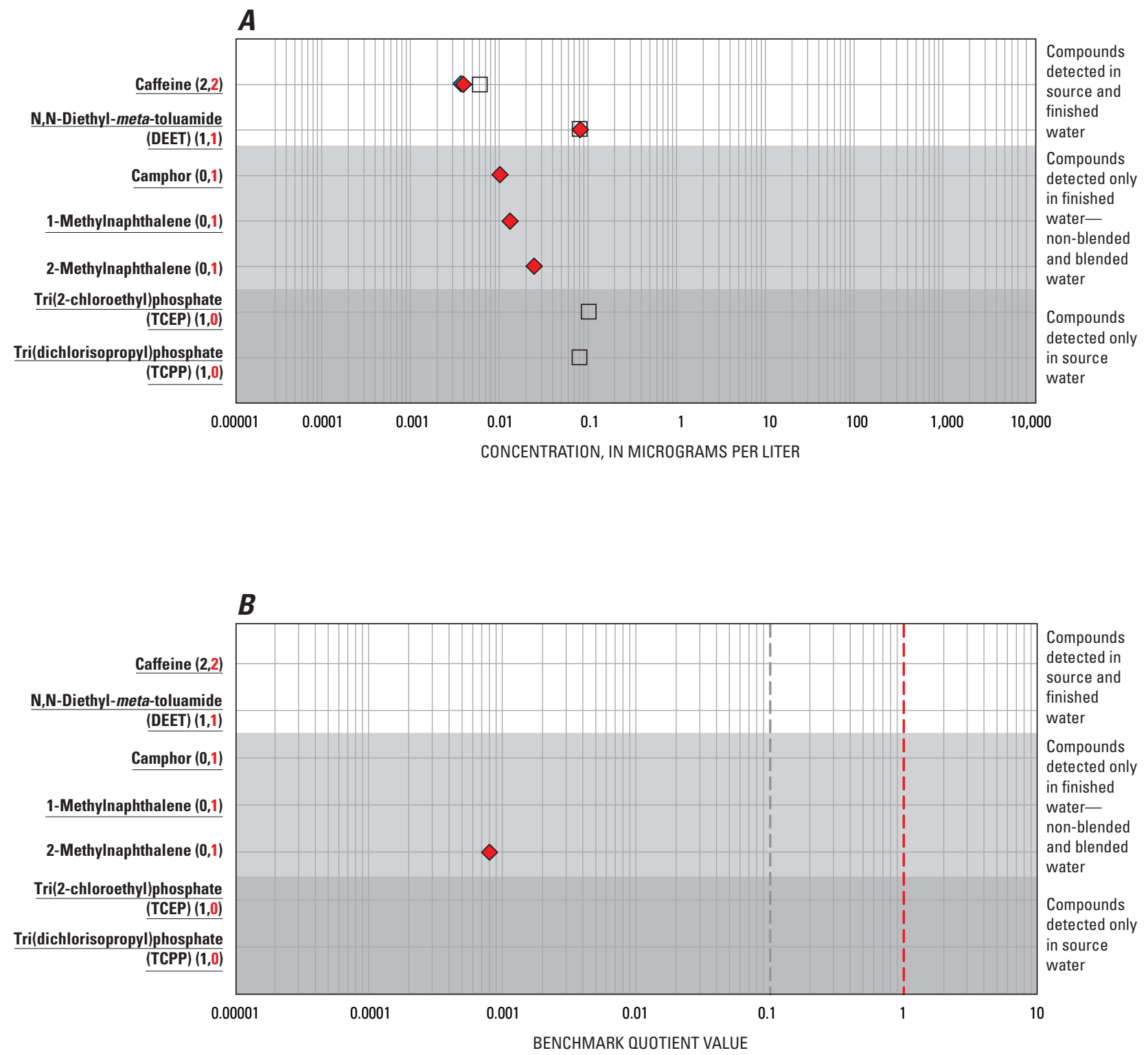

Caffeine (2,2)-Number of compounds detected for source water (2) and finished water (2); bold type indicates an unregulated compound; underlined indicates the unregulated compound does not have an HBSL

\section{EXPLANATION}

Benchmark quotient value of $0.1-$ Values equal to or greater than this line may warrant inclusion of the compound in a low-concentration, trends-monitoring program

I Benchmark quotient value of 1.0-

Values greater than this line indicate concentrations of potential humanhealth concern

[Benchmark quotient value is the ratio of the detected concentration of a particular compound to its Maximum Contamination Level, MCL; or Health Based Screening Level, HBSL]

Figure 11. Detected anthropogenic organic compounds in source water and associated finished water (blended) during phase 2 showing $(A)$ concentrations and number of detections, and $(B)$ benchmark quotient values. 


\section{Summary}

As part of the U.S. Geological Survey (USGS) National Water-Quality Assessment (NAWQA) Program, a new sampling activity called Source Water-Quality Assessments (SWQAs) commenced in 2002. SWQAs consist of two sampling phases. Phase 1 was designed to evaluate the occurrence of 258 anthropogenic organic compounds (AOCs) in the ground water used as source water for some of the highest producing community water system (CWS) wells in the sampling area. The AOCs monitored include volatile organic compounds (VOCs), pesticides, and other anthropogenic organic compounds (OAOCs). Phase 2 was designed to monitor those AOCs that occurred most frequently during phase 1 sampling and characterizes AOC occurrence in source water as well as in the associated finished water prior to distribution. This report presents the results of an SWQA conducted in the unconfined and semiconfined portions of the Upper Floridan aquifer system through monitoring 30 of the largest producing CWS wells in the northern Tampa Bay area, Florida.

During phase 1 of the SWQA, 31 of the 258 AOCs were detected (11 VOCs, 12 pesticides, and 8 OAOCs) in sourcewater samples collected between October 2002 and January 2003. The 10 most frequently detected AOCs in source water occurred in at least 13 percent of samples and 12 AOCs occurred in at least 10 percent of samples. Samples generally contained a mixture of compounds (average of three AOCs per sample), and 70 percent of samples contained at least one detected compound.

Concentrations of 16 of the 31 detected compounds were compared to human-health benchmarks (Maximum Contaminant Levels (MCLs) for regulated compounds and Health-Based Screening Levels (HBSLs) for unregulated compounds). For these 16 compounds, concentrations were well below their human-health benchmarks, are unlikely to be of potential human-health concern, and may not warrant consideration in a low-concentration, trends-monitoring program. HBSLs were not available for the remaining 15 detected unregulated AOCs because human-health toxicity information was not available. However, additional monitoring may be warranted for 2 of these 15 unregulated AOCs-1,2,4-trimethylbenzene and deethylatrazine-to better understand their temporal and spatial occurrence and their sources, transport, and fate because they were frequently detected in source-water samples.

Population density was determined to provide the best estimate of the number of AOCs in source water. However, hydrogeology also plays an important role in the detection of AOCs in source-water samples from CWS wells, especially for VOCs and pesticides. OAOCs, on the other hand, may have more specific sources and (or) pathways to enter the environment, such as wastewater from wastewater-treatment plants and (or) septic tank effluent. Of 31 AOCs detected a total of 97 times, there were almost twice as many detections in the unconfined areas (62) as in the semiconfined areas of the Upper Floridan aquifer (35). There were 27 detections of VOCs in the unconfined areas, and 8 detections of VOCs in the semiconfined areas of the Upper Floridan aquifer. Similarly, there were 34 detections of pesticides in the unconfined areas, and 14 detections in the semiconfined areas of the Upper Floridan aquifer. In contrast to VOCs and pesticides, one OAOC was detected in one source-water sample from the unconfined areas, and 13 OAOCs were detected in semiconfined areas. Little is known about the persistence and mobility of OAOCs in ground water, but many of the detections in this study appear to be more site specific than regionally widespread. Nine of the 14 detections of OAOCs occurred in two well samples from semiconfined areas of the Upper Floridan aquifer; 6 in one well sample and 3 in the other sample. These wells were located near facilities that utilize septic systems.

Results from the 30 CWS wells sampled during phase 1 in this SWQA study were compared to four locally conducted studies that characterized VOCs, pesticides, and (or) OAOCs in the Upper Floridan aquifer in the northern Tampa Bay area or in the Biscayne aquifer in Miami-Dade, Broward, and Palm Beach Counties. These general comparisons indicate that VOCs that occurred relatively infrequently in other studies of the Upper Floridan aquifer also tend to be found infrequently in source water of large CWSs in the area. Similarly, those VOCs found to occur most frequently in other studies also tend to be found relatively frequently in source water; particularly chloroform, carbon disulfide, and perchloroethene (PCE). However, pesticide compounds, especially atrazine and its breakdown products deethylatrazine and 2-hydroxyatrazine, occurred more frequently in the source water monitored in the SWQA study than in other studies. Thus, the VOC results from other studies may be somewhat representative of the quality of source water used by CWSs in the area but are not necessarily representative for selected pesticides. Several VOCs and pesticides were detected more frequently in a study of the Biscayne aquifer than in this SWQA. This may be explained, in part, by the high permeability of the sand and limestone sediments and shallow water table of the Biscayne aquifer, in comparison to the Upper Floridan aquifer, which makes these ground waters more vulnerable to contamination by human activities. In contrast VOCs and pesticides, which have been monitored for several years, comparison of OAOC results to other studies is difficult because the analytical methods were more recently developed.

Eleven of the $30 \mathrm{CWS}$ wells along with their associated finished water were resampled during phase 2 , and samples were analyzed for those AOCs that occurred most frequently during phase 1 sampling. For the 11 finished-water samples, 5 were blended with ground water from other CWS wells. Ten pairs of source water and finished water were analyzed for VOCs, 6 for pesticides, and 2 for OAOCs. Overall, 42 AOCs were detected in either source water or finished water and more compounds were detected in finished water than in source water. Specifically, 22 individual AOCs (8 VOCs, 
10 pesticides, and 4 OAOCs) were detected in source water and 27 (14 VOCs, 8 pesticides, and 5 OAOCs) were detected in finished water. The total number of detections also were greater in the finished water (80) than in the source water (49); however, this was largely due to the creation of disinfection by-products in the finished water. Excluding DBPs, about the same number of total detections was observed in source water (40) as in finished water (44). Samples generally contained a mixture of compounds with an average of 4 compounds in source water and 7 compounds in finished water.

AOC concentrations ranged from E0.001 (estimated) to $1,140 \mu \mathrm{g} / \mathrm{L}$ in source water and from E0.003 to $36.3 \mu \mathrm{g} / \mathrm{L}$ in finished water. Human-health benchmarks were available for 24 of the 42 compounds detected in either source water or finished water. Concentrations were about 1 to 5 orders of magnitude less than human-health benchmarks, indicating that these concentrations are unlikely to be of potential human-health concern. The potential human-health relevance for the remaining 18 detected unregulated AOCs could not be evaluated at this time because human-health toxicity information necessary to calculate HBSLs for these compounds was not available.

Concentrations for 3 AOCs detected in finished water and 1 AOC in source water were within a factor of 10 of humanhealth benchmarks, which is considered a level that may warrant inclusion in a low-concentration, trends-monitoring program. However, two of these AOCs-chloroform and dibromochloromethane-are disinfection by-products already monitored routinely by CWSs, and methyl ethyl ketone was detected in only one source-water sample. Carbon tetrachloride was detected in three finished-water samples and, thus, may be warranted for inclusion in such a monitoring program.

More data are needed to determine how source water compares to finished water. However, in this study, VOCs monitored in source water does not necessarily reflect the occurrence of VOCs in finished water. This is especially true for compounds that are formed as a result of disinfection. In addition, 14 of the 18 VOCs were detected in either the source water or finished water, but not both. These differences may be largely due to blending. That is, VOCs present in source water but not the finished water may have been diluted to undetectable concentrations in the finished water by blending with other source water that did not contain those VOCs. Similarly, VOCs present in the finished water but not the source water sample, in part, may have been present in the source water from other wells that composed the blended finished water. However, these results indicate that monitoring pesticides in source water may approximate the occurrence of pesticides in finished water, especially for atrazine and its breakdown products. Although the effect of blending makes it difficult to quantitatively characterize how representative source water is of finished water without monitoring each CWS well contributing to the blended finished water, this study determined that many pesticides were detected more frequently in source water than finished water.

\section{References Cited}

Barbash, J.E., and Resek, E.A., 1996, Pesticides in ground water-Distribution, trends, and governing factors: Chelsea, Mich., Ann Arbor Press, Pesticides in the Hydrologic System Series, v. 2, 590 p.

Barbash, J.E., Thelin, G.P., Kolpin, D.W., and Gilliom, R.J., 1999, Distribution of major herbicides in ground water of the United States: U.S. Geological Survey Water-Resources Investigations Report 98-4245, 57 p.

Bradner, Anne, McPherson, B.F., Miller, R.L., Kish, George, and Bernard, Bruce, 2005, Quality of ground water in the Biscayne aquifer in Miami-Dade, Broward, and Palm Beach Counties, Florida, 1996-1998, with emphasis on contaminants: U.S. Geological Survey Open-File Report 2004-1438, 20 p.

Bush, P.W., and Johnston, R.H., 1988, Ground-water hydraulics, regional flow, and ground-water development of the Floridan aquifer system in Florida and in parts of Georgia, South Carolina, and Alabama-Regional AquiferSystem Analysis: U.S. Geological Survey Professional Paper 1403-C, 80 p.

Carter, J.M., Delzer, G.C., Kingsbury, J.A., and Hopple, J.A., 2007, Concentration data for anthropogenic organic compounds in ground water, surface water, and finished water of selected community water systems in the United States, 2002-05: U.S. Geological Survey Data Series 268, 30 p., accessed May 29, 2007, at http://pubs.usgs.gov/ $d s / 2007 / 268 /$.

Connor, B.F., Rose, D.L., Noriega, M.C., Murtagh, L.K., and Abney, S.R., 1998, Methods of analysis by the U.S. Geological Survey National Water Quality Laboratory-Determination of 86 volatile organic compounds in water by gas chromatography/mass spectrometry, including detections less than reporting limits: U.S. Geological Survey Open-File Report 97-829, $78 \mathrm{p}$.

Coupe, R.H., and Blomquist, J.D., 2004, Water-soluble pesticides in finished water of community water supplies: Journal of the American Water Resources Association, v. 96 , no. 10 , p. $56-68$.

Denver, J.M., and Sandstrom, M.W., 1991, Distribution of dissolved atrazine and two metabolites in the unconfined aquifer, southeastern Delaware, in Mallard, G.E., and Aronson, D.A., eds., U.S. Geological Survey Toxic Substances Hydrology Program-Proceedings of the technical meeting, Monterey, California, March 11-15, 1991: U.S. Geological Survey WaterResources Investigations Report 91-4034, p. 314-318. 
Furlong, E.T., Anderson, B.D., Werner, S.L., Soliven, P.P., Coffey, L.J., and Burkhardt, M.R., 2001, Methods of analysis by the U.S. Geological Survey National Water Quality Laboratory-Determination of pesticides in water by graphitized carbon-based solid-phase extraction and high-performance liquid chromatography/mass spectrometry: U.S. Geological Survey Water-Resources Investigations Report 01-4134, 73 p.

Gaus, Irena, 2000, Effects of water extraction in a vulnerable phreatic aquifer-Consequences for groundwater contamination by pesticides, Sint-Jansteen area, The Netherlands: Journal of Hydrology, v. 8, p. 218-229.

Herberer, Thomas, 2002, Occurrence, fate, and removal of pharmaceutical residues in the aquatic environment-A review of recent research data: Toxicology Letters, v. 131, p. 5-17.

Ivahnenko, Tamara, and Barbash, J.E., 2004, Chloroform in the hydrologic system-Sources, transport, fate, occurrence, and effects on human health and aquatic organisms: U.S. Geological Survey Scientific Investigations Report 2004-5137, 34 p.

Koterba, M.T., Wilde, F.D., and Lapham, W.W., 1995, Ground-water-data-collection protocols and procedures for the National Water-Quality Assessment Program collection and documentation of water-quality samples and related data: U.S. Geological Survey Open-File Report 95-399, $113 \mathrm{p}$.

Kruger, E.L., Zhu Beilei, and Coats, J.R., 1995, Relative mobilities of atrazine, five atrazine degradates, metolachlor, and simazine in soils of Iowa: Environmental Toxicology and Chemistry, v. 15, no. 5, p. 691-695.

Lindley, C.E., Stewart, J.T., and Sandstrom, M.W., 1996, Determination of low concentrations of acetochlor in water by automated solid-phase extraction and gas chromatography with mass selective detection: Journal of Association of Official Analytical Chemists International, v. 79, no. 4, p. 962-966.

Loraine, G.A., and Pettigrove, M.E., 2006, Seasonal variations in concentrations of pharmaceuticals and personal care products in drinking water and reclaimed wastewater in southern California: Environmental Science and Technology, v. 40, p. 687-695.

Madsen, J.E., Sandstrom, M.W., and Zaugg, S.D., 2003, Methods of analysis by the U.S. Geological Survey National Water Quality Laboratory-A method supplement for the determination of fipronil and degradates in water by gas chromatography/mass spectrometry: U.S. Geological Survey Open-File Report 02-462, 11 p.
Metz, P.A., and Sacks, L.A., 2002, Comparison of the hydrogeology and water quality of a ground-water augmented lake with two non-augmented lakes in northwest Hillsborough County, Florida: U.S. Geological Survey Water-Resources Investigations Report 02-4032, 74 p.

Phelps, G.G., 2004, Chemistry of ground water in the Silver Springs Basin, Florida, with an emphasis on nitrate: U.S. Geological Survey Scientific Investigations Report 2004-5144, 54 p.

Sandstrom, M.W., Kolpin, D.W., Thurman, E.M., and Zaugg, S.D., 2005, Widespread detection of $\mathrm{N}, \mathrm{N}$-diethyl- $m$-toluamide in U.S. streams-Comparison with concentrations of pesticides, personal care products, and other organic wastewater compounds: Environmental Toxicology and Chemistry, v. 24, no. 5, p. 1,029-1,034.

Sandstrom, M.W., Stroppel, M.E., Foreman, W.T., and Schroeder, M.P., 2001, Methods of analysis by the U.S. Geological Survey National Water Quality Laboratory-Determination of moderate-use pesticides and selected degradates in water by $\mathrm{C}-18$ solid-phase extraction and gas chromatography/mass spectrometry: U.S. Geological Survey Water-Resources Investigations Report 01-4098, 70 p.

Sinclair, W.C., 1974, Hydrogeologic characteristics of the surficial aquifer in northwest Hillsborough County, Florida: Florida Bureau of Geology Information Circular 86, 98 p.

Stackelberg, P.E., Furlong, E.T., Meyer, M.T., Zaugg, S.D., Henderson, A.K., Reissman, D.B., 2004, Persistence of pharmaceutical compounds and other organic wastewater contaminants in a conventional drinking-water-treatment plant: Science of the Total Environment, v. 329, no. 1-3, p. 99-113.

Statistical Analysis System Institute, 1989, SAS/STAT User's Guide, Fourth Edition, Volume 2: Cary, North Carolina, SAS Institute Inc., 846 p.

Ternes, T.A., Meisenheimer, M., McDowell, D., Sacher, F., Branch H.J., Hsiate-Guide, B., Preuss, G., Wilme, U., and Zulei-Seibert, N., 2002, Removal of pharmaceuticals during drinking water treatment: Environmental Science and Technology, v. 36, p. 3,855-3,863.

Thiros, S.A., 2000, Quality of shallow ground water in areas of recent residential and commercial development in Salt Lake Valley, Utah, 1999: U.S. Geological Survey Fact Sheet 106-00, 6 p.

Timme, P.J., 1995, National Water Quality Laboratory 1995 Services Catalog: U.S. Geological Survey Open-File Report 95-352, $120 \mathrm{p}$. 
Toccalino, P.L., Norman, J.E., Booth, N.L., and Zogorski, J.S., 2006a, Health-based screening levels-A tool for evaluating what what-quality data may mean to human health: U.S. Geological Survey, National Water-Quality Assessment Program, October 2006, accessed May 29, 2007, at http://water.usgs.gov/nawqa/HBSL/.

Toccalino, P.L., Norman, J.E., Phillips, R.H., Kauffman, L.J., Stackelberg, P.E., Nowell, L.H., Krietzman, S.J., and Post, G.B., 2004, Application of Health-Based Screening Levels to ground-water quality data in a State-scale pilot effort: U.S. Geological Survey Scientific Investigations Report 2004-5174, 64 p.

Toccalino, P.L., Nowell, L.H., Wilber, W.G., Zogorski, J.S., Donohue, Joyce, Eiden, C., Krietzman, S., and Post, G., 2003, Development of Health-Based Screening Levels for use in State- or local-scale water-quality assessments: U.S. Geological Survey Water-Resources Investigations Report 03-4054, 22 p.

Toccalino, P.L., Rowe, B.L., and Norman, J.E., 2006b, Volatile organic compounds in the Nation's drinking-water supply wells - What findings may mean to human health: U.S. Geological Survey Fact Sheet 2006-3043, 4 p.

Toccalino, P.L., Zogorski, J.S., and Norman, J.E., 2005, Health-Based Screening Levels and their application to water-quality data: U.S. Geological Survey Fact Sheet 2005-2059, 2 p.

U.S. Census Bureau, 2002, Florida: Population of counties by decennial census: 1900-1990, Forstall, R.L., ed.: accessed September 29, 2004, at http://factfinder.census.gov/servlet/ DatasetMainPageServlet?_lang=en\&_ts $=114525133172 \&$ _ ds_\%20name=DEC_\%201990_STF1_\&_program=

U.S. Environmental Protection Agency, 1998, R.E.D. Facts-DEET: U.S. Environmental Protection Agency EPA-738-F-95-010, accessed Sept. 2003 at http://www. epa.gov/oppsrrd1/REDs/factsheets/0002fact.pdf

U.S. Environmental Protection Agency, 2003, Code of Federal Regulations, title 40 - Protection of environment, chapter 1 - Environmental Protection Agency, subchapter D - water programs, part 141 - National primary drinking water regulations, definitions: Washington, D.C., National Archives and Records Administration, 40 CFR 141.2, accessed July 1, 2003, at http://www.gpoaccess.gov/ecfr/ index.html
U.S. Environmental Protection Agency, 2004, 2004 Edition of the drinking water standards and health advisories: Washington, D.C., U.S. Environmental Protection Agency, Office of Water, EPA 822-R-04-005, Winter 2004, 20 p., accessed May 29, 2007, at http://www.epa.gov/ waterscience/drinking/standards/dwstandards.pdf

U.S. Environmental Protection Agency, 2006, Setting standards for safe drinking water: U.S. Environmental Protection Agency, Office of Ground Water and Drinking Water, accessed May 29, 2007, at http://www.epa.gov/ safewater/standard/setting.html

Vogelmann, J.E., Howard, S.M., Yang, L., Larson, C.R., Wylie, B.K., and Van Driel, J.N., 2001, Completion of the 1990s National Land Cover Data Set for the conterminous United States, Photogrammetric Engineering and Remote Sensing, v. 67, p. 650-662.

Weigel, Stefan; Kuhlmann, Jan; and Hühnerfuss, Heinrich, 2002, Drugs and personal care products as ubiquitous pollutants-Occurrence and distribution of clofibric acid, caffeine, and DEET in the North Sea: Science of the Total Environment, v. 295, p. 131-141.

Westerhoff, Paul; Yoon, Yeomin; Snyder, Shane; and Wert, Eric, 2005, Fate of endocrine-disruptor, pharmaceutical, and personal care product chemicals during simulated drinking water treatment processes: Environmental Science and Technology, v. 39, no. 17, p. 6,649-6,663.

Winslow, S.D., Prakash, B., Domino, M.M., and Pepich, B.V., 2001, Considerations necessary in gathering occurrence data for selected unstable compounds in the USEPA unregulated contaminant candidate list in USEPA method 526: Environmental Science \& Technology, v. 35, no. 9 , p 1,851-1,858.

Zaugg, S.D., Sandstrom, M.W., Smith, S.G., and Fehlberg, K.M., 1995, Methods of analysis by the U.S. Geological Survey National Water Quality Laboratory-Determination of pesticides in water by $\mathrm{C}-18$ solid-phase extraction and capillary-column gas chromatography/mass spectrometry with selected-ion monitoring: U.S. Geological Survey Open-File Report 95-181, 60 p.

Zaugg, S.D., Smith, S.G., Schroeder, M.P., Barber, L.B., and Burkhardt, M.R., 2002, Methods of analysis by the U.S. Geological Survey National Water Quality Laboratory-Determination of wastewater compounds by polystyrene-divinylbenzene solid-phase extraction and capillary-column gas chromatography/mass spectrometry: U.S. Geological Survey Water-Resources Investigations Report 01-4186, 37 p. 
This page intentionally left blank. 


\section{Appendixes}

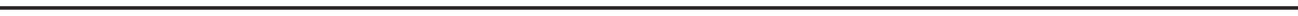


This page intentionally left blank. 
Appendix 1. Volatile organic compounds analyzed in this study.

[CASRN, Chemical Abstracts Service Registry Number; $\mu \mathrm{g} / \mathrm{L}$, micrograms per liter; NA, not available; HBSL, Health-Based Screening Level; MCL, Maximum Contaminant Level; Gasoline, compounds that include gasoline hydrocarbons, oxygenates, and oxygenate degradates]

\begin{tabular}{|c|c|c|c|c|}
\hline $\begin{array}{l}\text { Regulated (R) or unregulated (U) } \\
\text { compound (alternate name) }\end{array}$ & CASRN & $\begin{array}{c}\text { Minimum } \\
\text { reporting } \\
\text { level, } \\
\text { in } \mu \mathrm{g} / \mathrm{L}\end{array}$ & $\begin{array}{c}\text { Type of } \\
\text { human-health } \\
\text { benchmark }\end{array}$ & Primary use or source \\
\hline Acetone (U) & $67-64-1$ & 6 & HBSL & Solvent. \\
\hline Acrylonitrile (U) & $107-13-1$ & .8 & HBSL & Organic synthesis compound. \\
\hline tert-Amyl alcohol (U) & $75-85-4$ & 1 & NA & Gasoline. \\
\hline Benzene (R) & $71-43-2$ & .021 & MCL & Gasoline. \\
\hline Bromobenzene (U) & $108-86-1$ & .028 & NA & Solvent. \\
\hline Bromochloromethane (U) & $74-97-5$ & .12 & HBSL & $\begin{array}{l}\text { Personal care and domestic use } \\
\text { products. }\end{array}$ \\
\hline n-Butylbenzene (U) & $104-51-8$ & .14 & NA & Gasoline. \\
\hline sec-Butylbenzene (U) & $135-98-8$ & .06 & NA & Gasoline. \\
\hline tert-Butylbenzene (U) & $98-06-6$ & .08 & NA & Gasoline. \\
\hline Carbon disulfide (U) & $75-15-0$ & .038 & HBSL & Organic synthesis compound. \\
\hline Carbon tetrachloride (R) & $56-23-5$ & .06 & MCL & Solvent. \\
\hline Chlorobenzene (R) & $108-90-7$ & .028 & MCL & Solvent. \\
\hline Chloroethane (U) & $75-00-3$ & .12 & NA & Solvent. \\
\hline Chloroform (R) & $67-66-3$ & .024 & $\mathrm{MCL}^{1}$ & Disinfection by-product. \\
\hline 1,2-Dibromoethane (R) (EDB) & $106-93-4$ & .036 & MCL & Fumigant related compound. \\
\hline Dibromomethane (U) & $74-95-3$ & .05 & NA & Solvent. \\
\hline 1,2-Dichlorobenzene (R) (o-dichlorobenzene) & $95-50-1$ & .048 & MCL & Solvent. \\
\hline 1,3-Dichlorobenzene (U) ( $m$-dichlorobenzene) & $541-73-1$ & .03 & HBSL & Solvent. \\
\hline 1,4-Dichlorobenzene (R) ( $p$-dichlorobenzene) & $106-46-7$ & .034 & MCL & Fumigant related compound. \\
\hline Dichlorodifluoromethane (U) (Freon 12) & $75-71-8$ & .18 & HBSL & Refrigerants and propellants. \\
\hline trans-1,4-Dichloro-2-butene (U) & $110-57-6$ & .7 & NA & Organic synthesis compound. \\
\hline 1,1-Dichloroethane (U) & $75-34-3$ & .035 & NA & Solvent. \\
\hline 1,2-Dichloroethane (ethylene dichloride) (R) & $107-06-2$ & .13 & MCL & Solvent. \\
\hline 1,1-Dichloroethene (R) & $75-35-4$ & .024 & MCL & Solvent. \\
\hline cis-1,2-Dichloroethene (R) & $156-59-2$ & .024 & MCL & Solvent. \\
\hline trans-1,2-Dichloroethene (R) & $156-60-5$ & .032 & MCL & Solvent. \\
\hline 1,2-Dichloropropane (R) & $78-87-5$ & .029 & MCL & Fumigant related compound. \\
\hline
\end{tabular}


Appendix 1. Volatile organic compounds analyzed in this study.-Continued

[CASRN, Chemical Abstracts Service Registry Number; $\mu \mathrm{g} / \mathrm{L}$, micrograms per liter; NA, not available; HBSL, Health-Based Screening Level; MCL, Maximum Contaminant Level; Gasoline, compounds that include gasoline hydrocarbons, oxygenates, and oxygenate degradates]

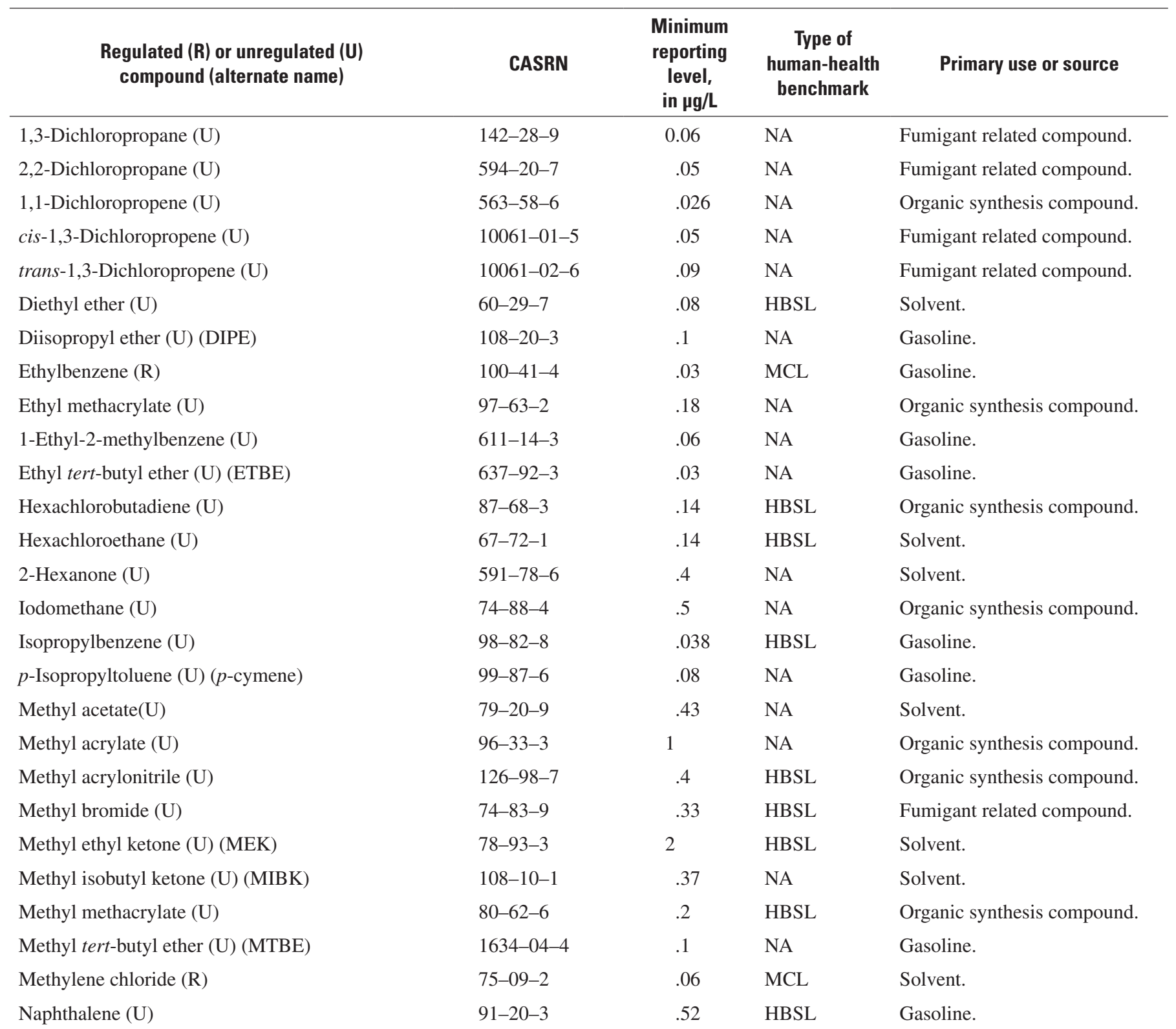


Appendix 1. Volatile organic compounds analyzed in this study.-Continued

[CASRN, Chemical Abstracts Service Registry Number; $\mu \mathrm{g} / \mathrm{L}$, micrograms per liter; NA, not available; HBSL, Health-Based Screening Level; MCL, Maximum Contaminant Level; Gasoline, compounds that include gasoline hydrocarbons, oxygenates, and oxygenate degradates]

\begin{tabular}{|c|c|c|c|c|}
\hline $\begin{array}{l}\text { Regulated (R) or unregulated (U) } \\
\text { compound (alternate name) }\end{array}$ & CASRN & $\begin{array}{l}\text { Minimum } \\
\text { reporting } \\
\text { level, } \\
\text { in } \mu \mathrm{g} / \mathrm{L}\end{array}$ & $\begin{array}{c}\text { Type of } \\
\text { human-health } \\
\text { benchmark }\end{array}$ & Primary use or source \\
\hline Perchloroethene (R) (PCE) & $127-18-4$ & 0.03 & MCL & Solvent. \\
\hline$n$-Propylbenzene (U) & $103-65-1$ & .042 & NA & Solvent. \\
\hline Styrene $(\mathrm{R})$ & $100-42-5$ & .042 & MCL & Gasoline. \\
\hline 1,1,2,2-Tetrachloroethane (U) & $79-34-5$ & .08 & HBSL & Solvent. \\
\hline Tetrahydrofuran (U) & 109-99-9 & 1.2 & NA & Solvent. \\
\hline 1,2,3,4-Tetramethylbenzene (U) & $488-23-3$ & .14 & NA & Gasoline. \\
\hline 1,2,3,5-Tetramethylbenzene (U) & $527-53-7$ & .18 & NA & Gasoline. \\
\hline 1,1,1-Trichloroethane $(\mathrm{R})$ & $71-55-6$ & .032 & $\mathrm{MCL}$ & Solvent. \\
\hline Trichloroethene (R) & $79-01-6$ & .038 & MCL & Solvent. \\
\hline Trichlorofluoromethane (U) (CFC-11) & $75-69-4$ & .08 & HBSL & Refrigerants and propellants. \\
\hline 1,2,3-Trichloropropane (U) & $96-18-4$ & .18 & HBSL & Organic synthesis compound. \\
\hline 1,1,2-Trichloroethane $(\mathrm{R})$ & $79-00-5$ & .04 & MCL & Solvent. \\
\hline $\begin{array}{l}\text { 1,1,2-Trichloro-1,2,2-trifluoroethane (U) } \\
\quad \text { (Freon 113) }\end{array}$ & $76-13-1$ & .038 & HBSL & Refrigerants and propellants. \\
\hline 1,2,3-Trimethylbenzene (U) & $526-73-8$ & .09 & NA & Gasoline. \\
\hline$o$-Xylene (R) & $95-47-6$ & .038 & $\mathrm{MCL}^{2}$ & Gasoline. \\
\hline
\end{tabular}

${ }^{1} \mathrm{MCL}$ is for sum of the trihalomethanes.

${ }^{2} \mathrm{MCL}$ is for total xylene. 
Appendix 2. Pesticides and pesticide degradates analyzed in this study:

[CASRN, Chemical Abstracts Service Registry Number; $\mu \mathrm{g} / \mathrm{L}$, micrograms per liter; NA, not available; HBSL, Health-Based Screening Level; MCL, Maximum Contaminant Level]

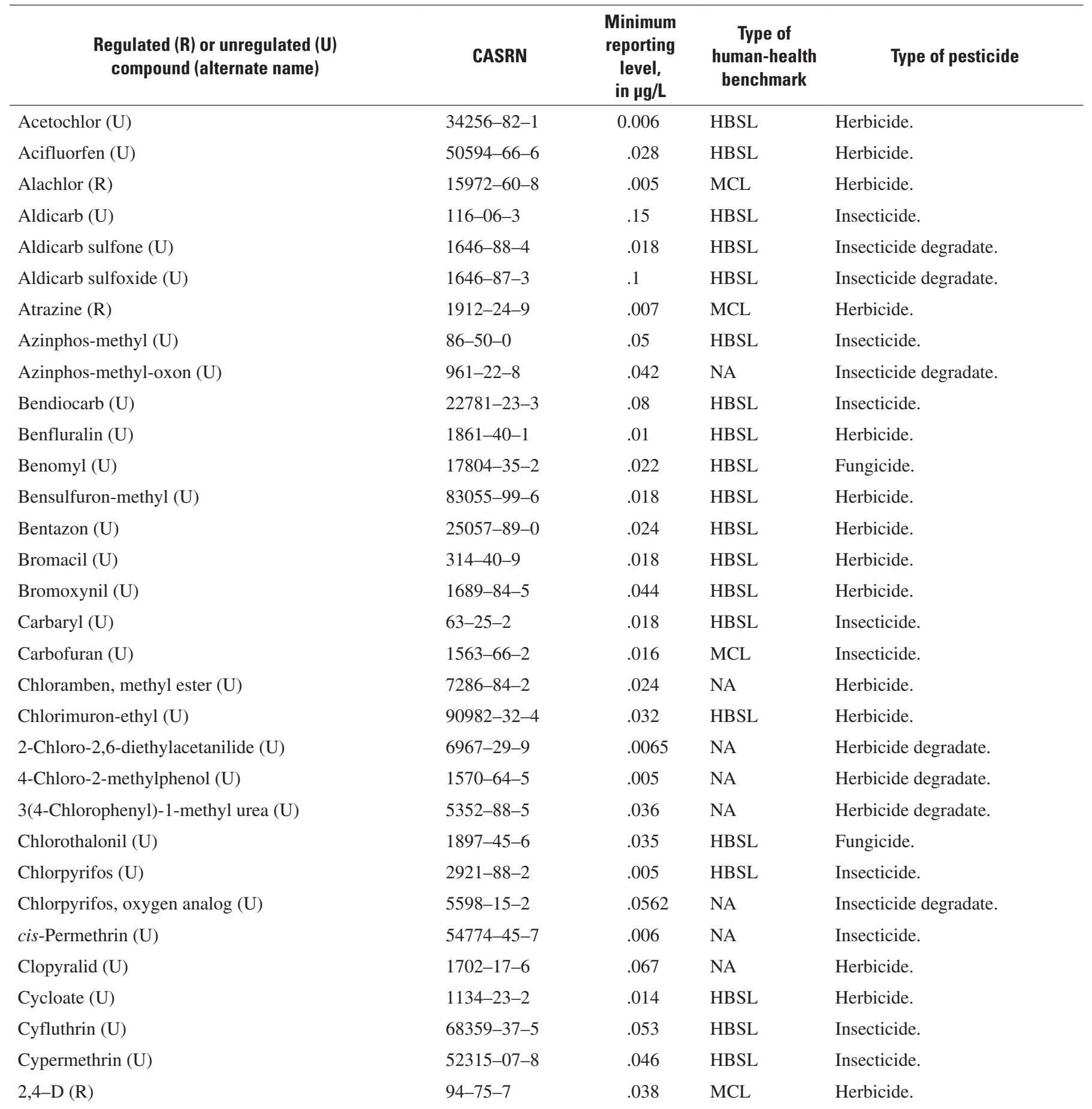


Appendix 2. Pesticides and pesticide degradates analyzed in this study.-Continued

[CASRN, Chemical Abstracts Service Registry Number; $\mu \mathrm{g} / \mathrm{L}$, micrograms per liter; NA, not available; HBSL, Health-Based Screening Level; MCL, Maximum Contaminant Level]

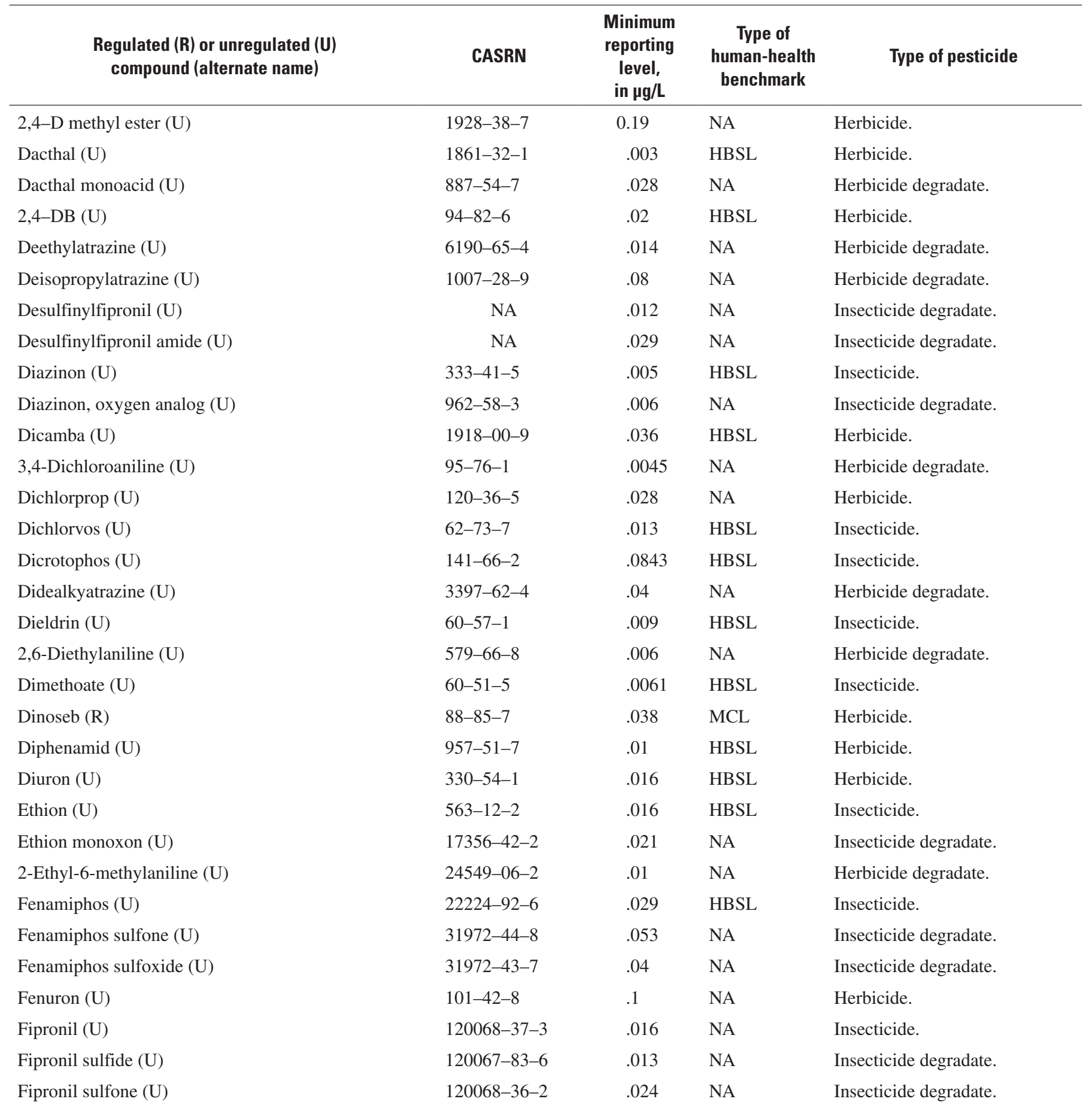


Appendix 2. Pesticides and pesticide degradates analyzed in this study.-Continued

[CASRN, Chemical Abstracts Service Registry Number; $\mu \mathrm{g} / \mathrm{L}$, micrograms per liter; NA, not available; HBSL, Health-Based Screening Level; MCL, Maximum Contaminant Level]

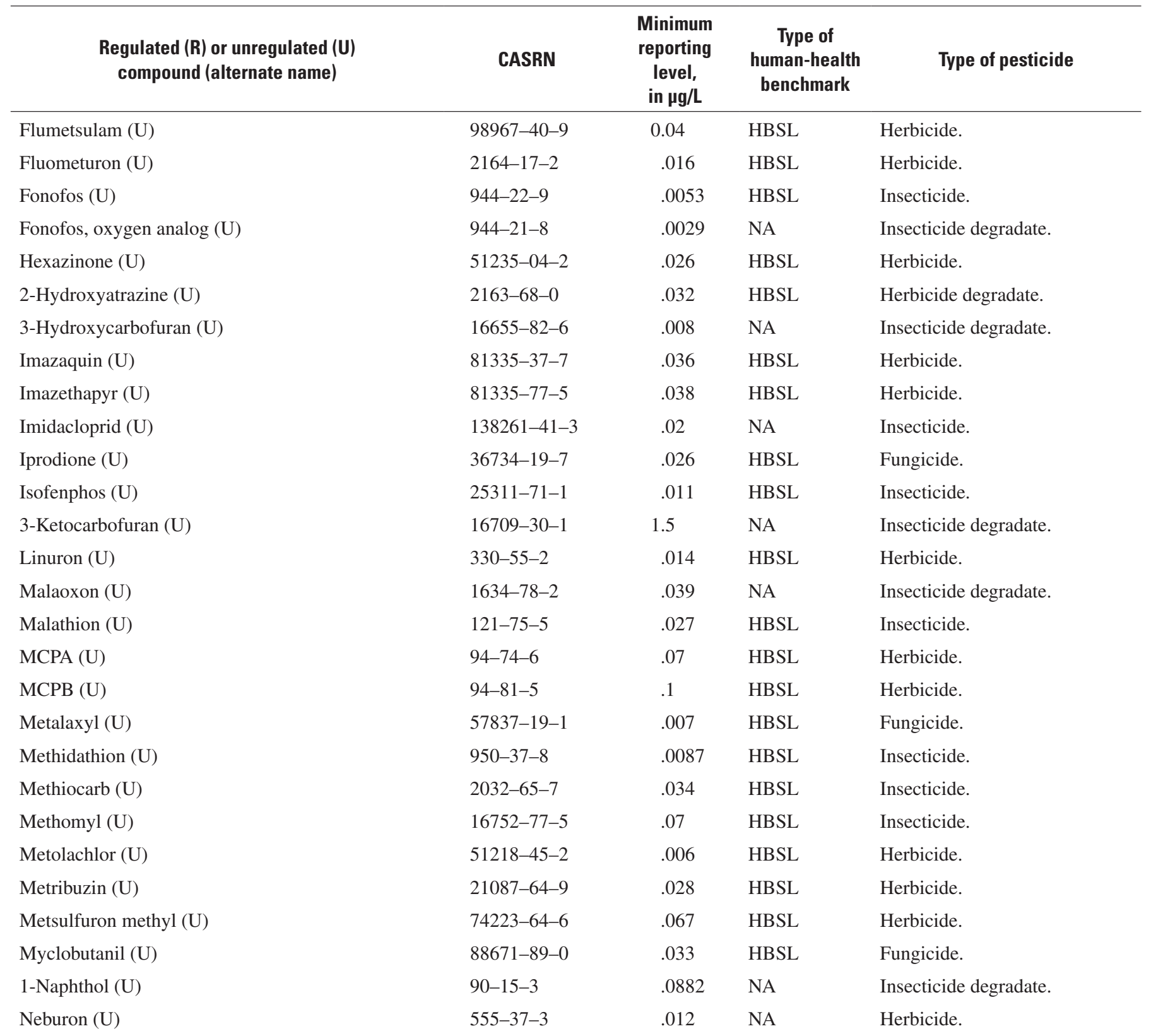


Appendix 2. Pesticides and pesticide degradates analyzed in this study.-Continued

[CASRN, Chemical Abstracts Service Registry Number; $\mu \mathrm{g} / \mathrm{L}$, micrograms per liter; NA, not available; HBSL, Health-Based Screening Level; MCL, Maximum Contaminant Level]

\begin{tabular}{|c|c|c|c|c|}
\hline $\begin{array}{l}\text { Regulated (R) or unregulated (U) } \\
\text { compound (alternate name) }\end{array}$ & CASRN & $\begin{array}{c}\text { Minimum } \\
\text { reporting } \\
\text { level, } \\
\text { in } \mu \mathrm{g} / \mathrm{L}\end{array}$ & $\begin{array}{c}\text { Type of } \\
\text { human-health } \\
\text { benchmark }\end{array}$ & Type of pesticide \\
\hline Nicosulfuron (U) & 111991-09-4 & 0.04 & HBSL & Herbicide. \\
\hline Norflurazon (U) & $27314-13-2$ & .02 & HBSL & Herbicide. \\
\hline Oryzalin (U) & $19044-88-3$ & .023 & HBSL & Herbicide. \\
\hline Paraoxon-methyl (U) & $950-35-6$ & .019 & NA & Insecticide degradate. \\
\hline Parathion-methyl (U) & $298-00-0$ & .015 & HBSL & Insecticide. \\
\hline Pendimethalin (U) & $40487-42-1$ & .022 & HBSL & Herbicide. \\
\hline Phorate (U) & $298-02-2$ & .055 & HBSL & Insecticide. \\
\hline Picloram (U) & $1918-02-1$ & .032 & NA & Herbicide. \\
\hline Prometon $(\mathrm{U})$ & $1610-18-0$ & .01 & HBSL & Herbicide. \\
\hline Prometryn (U) & $7287-19-6$ & .0059 & HBSL & Herbicide. \\
\hline Propham (U) & $122-42-9$ & .03 & HBSL & Herbicide. \\
\hline Propiconazole (U) & 60207-90-1 & .01 & HBSL & Fungicide. \\
\hline Propoxur (U) & $114-26-1$ & .008 & HBSL & Insecticide. \\
\hline Propyzamide (U) & $23950-58-5$ & .004 & HBSL & Herbicide. \\
\hline Siduron (U) & $1982-49-6$ & .02 & NA & Herbicide. \\
\hline Terbufos-O-analogue sulfone (U) & $56070-15-6$ & .045 & NA & Insecticide degradate. \\
\hline Terbuthylazine (U) & $5915-41-3$ & .0083 & HBSL & Herbicide. \\
\hline Triclopyr (U) & $55335-06-3$ & .026 & HBSL & Herbicide. \\
\hline Trifluralin (U) & $1582-09-8$ & .009 & HBSL & Herbicide. \\
\hline
\end{tabular}


Appendix 3. Other anthropogenic organic compounds analyzed in this study.

[CASRN, Chemical Abstracts Service Registry Number; $\mu \mathrm{g} / \mathrm{L}$, micrograms per liter; NA, not available; HBSL, Health-Based Screening Level; MCL, Maximum Contaminant Level; Gasoline, compounds that include gasoline hydrocarbons, oxygenates, and oxygenate degradates; Pavement \& combustion, includes polyaromatic hydrocarbon compounds present in pavement and released from the combustion of fossil fuels]

\begin{tabular}{|c|c|c|c|c|}
\hline $\begin{array}{l}\text { Regulated ( } R \text { ) or unregulated (U) } \\
\text { compound (alternate name) }\end{array}$ & CASRN & $\begin{array}{c}\text { Minimum } \\
\text { reporting } \\
\text { level, } \\
\text { in } \mu \mathrm{g} / \mathrm{L}\end{array}$ & $\begin{array}{c}\text { Type of } \\
\text { human-health } \\
\text { benchmark }\end{array}$ & Primary use or source \\
\hline Acetophenone (U) & $98-86-2$ & 0.5 & HBSL & Personal care and domestic use products. \\
\hline $\begin{array}{l}\text { Acetyl hexamethyl tetrahydronaphthalene (U) } \\
\text { (AHTN) }\end{array}$ & $21145-77-7$ & .5 & NA & Personal care and domestic use products. \\
\hline Anthraquinone (U) & $84-65-1$ & .5 & NA & Organic synthesis compound. \\
\hline Benzo $[a]$ pyrene & $50-32-8$ & .5 & MCL & Pavement \& combustion. \\
\hline Benzophenone (U) & $119-61-9$ & .5 & NA & Personal care and domestic use products. \\
\hline Bisphenol-A (U) & $80-05-7$ & 1 & HBSL & Manufacturing additive. \\
\hline Carbazole (U) & $86-74-8$ & .5 & NA & Organic synthesis compound. \\
\hline Cholesterol (U) & $57-88-5$ & 2 & NA & Plant- or animal-derived biochemical. \\
\hline 3-beta-Coprostanol (U) & $360-68-9$ & 2 & NA & Plant- or animal-derived biochemical. \\
\hline Cotinine (U) & $486-56-6$ & 1 & NA & Personal care and domestic use products. \\
\hline p-Cresol (U) & $106-44-5$ & 1 & NA & Solvent. \\
\hline 4-Cumylphenol (U) & $599-64-4$ & 1 & NA & Personal care and domestic use products. \\
\hline N,N-Diethyl-meta-toluamide (U) (DEET) & $134-62-3$ & .5 & NA & Personal care and domestic use products. \\
\hline 2,6-Dimethylnaphthalene (U) & $581-42-0$ & .5 & NA & Gasoline. \\
\hline Isoquinoline (U) & $119-65-3$ & .5 & NA & Personal care and domestic use products. \\
\hline$d$-Limonene $(\mathrm{U})$ & $5989-27-5$ & .5 & NA & Personal care and domestic use products. \\
\hline
\end{tabular}


Appendix 3. Other anthropogenic organic compounds analyzed in this study.-Continued

[CASRN, Chemical Abstracts Service Registry Number; $\mu \mathrm{g} / \mathrm{L}$, micrograms per liter; NA, not available; HBSL, Health-Based Screening Level; MCL, Maximum Contaminant Level; Gasoline, compounds that include gasoline hydrocarbons, oxygenates, and oxygenate degradates; Pavement \& combustion, includes polyaromatic hydrocarbon compounds present in pavement and released from the combustion of fossil fuels]

\begin{tabular}{|c|c|c|c|c|}
\hline $\begin{array}{l}\text { Regulated (R) or unregulated (U) } \\
\text { compound (alternate name) }\end{array}$ & CASRN & $\begin{array}{c}\text { Minimum } \\
\text { reporting } \\
\text { level, } \\
\text { in } \mu \mathrm{g} / \mathrm{L}\end{array}$ & $\begin{array}{c}\text { Type of } \\
\text { human-health } \\
\text { benchmark }\end{array}$ & Primary use or source \\
\hline Menthol (U) & $89-78-1$ & 0.5 & NA & Personal care and domestic use products. \\
\hline 5-Methyl-1H-benzotriazole (U) & $136-85-6$ & 2 & NA & Manufacturing additive. \\
\hline 3-Methyl-1(H)-indole (U) (Skatole) & $83-34-1$ & 1 & NA & Plant- or animal-derived biochemical. \\
\hline 2-Methylnaphthalene (U) & $91-57-6$ & .5 & HBSL & Gasoline. \\
\hline Methyl salicylate (U) & $119-36-8$ & .5 & NA & Personal care and domestic use products. \\
\hline 4-Nonylphenol (U) & $84852-15-3$ & 5 & NA & Personal care and domestic use products. \\
\hline $\begin{array}{l}\text { 4-Nonylphenol, diethoxylate (U) } \\
\text { (NPEO2-total) }\end{array}$ & $26027-38-2$ & 5 & NA & Personal care and domestic use products. \\
\hline 4-Octylphenol diethoxylate (U) (OPEO2) & $26636-32-8$ & 1 & NA & Personal care and domestic use products. \\
\hline 4-Octylphenol monoethoxylate (U) (OPEO1) & $26636-32-8$ & 1 & NA & Personal care and domestic use products. \\
\hline Pentachlorophenol (R) & $87-86-5$ & 2 & MCL & Fungicide. \\
\hline Phenanthrene (U) & $85-01-8$ & .5 & NA & Pavement \& combustion. \\
\hline Phenol (U) & $108-95-2$ & .5 & NA & Personal care and domestic use products. \\
\hline Pyrene (U) & $129-00-0$ & .5 & HBSL & Pavement \& combustion. \\
\hline beta-Sitosterol (U) & $83-46-5$ & 2 & NA & Plant- or animal-derived biochemicals. \\
\hline beta-Stigmastanol (U) & $19466-47-8$ & 2 & NA & Plant- or animal-derived biochemicals. \\
\hline Triphenyl phosphate (U) & $115-86-6$ & .5 & NA & Manufacturing additive. \\
\hline
\end{tabular}


42 Anthropogenic Organic Compounds in Ground and Finished Water in the Northern Tampa Bay Area, 2002-04

Appendix 4. Descriptions of human-health benchmarks related to drinking water.

[Maximum Contaminant Levels (MCLs) (Federal and State) are enforceable standards; Health-Based Screening Levels (HBSLs) are not enforceable guidelines; USGS, U.S. Geological Survey; USEPA, U.S. Environmental Protection Agency; OW, Office of Water]

\begin{tabular}{|c|c|c|c|c|}
\hline $\begin{array}{l}\text { Human-health } \\
\text { benchmark }\end{array}$ & Acronym & Agency & Description & References \\
\hline $\begin{array}{l}\text { Health-Based } \\
\text { Screening Level }\end{array}$ & HBSL & USGS & $\begin{array}{l}\text { Benchmark concentrations of contaminants in } \\
\text { water that may be of potential concern for human } \\
\text { health, if exceeded. HBSLs are non-enforceable } \\
\text { benchmarks that were developed by the USGS in } \\
\text { collaboration with USEPA and others using USEPA } \\
\text { methodologies for establishing drinking-water } \\
\text { guidelines and the most current, USEPA peer- } \\
\text { reviewed, publicly available human-health toxicity } \\
\text { information. }\end{array}$ & $\begin{array}{l}\text { Toccalino and others, } \\
2003 \text { and 2006a. }\end{array}$ \\
\hline $\begin{array}{l}\text { Maximum } \\
\text { Contaminant } \\
\text { Level (Federal) }\end{array}$ & USEPA MCL & USEPA (OW) & $\begin{array}{l}\text { Legally enforceable standard that sets the maximum } \\
\text { permissible level of a contaminant in water that } \\
\text { is delivered to any user of a public water system. } \\
\text { MCLs are set as close as feasible to Maximum } \\
\text { Contaminant Level Goals (MCLGs). An MCLG } \\
\text { is the maximum level of a contaminant in drinking } \\
\text { water at which no known or anticipated adverse } \\
\text { effect on the health of persons would occur, and } \\
\text { which allows an adequate margin of safety. MCLGs } \\
\text { are non-enforceable public health goals that take } \\
\text { into account the best available technology, treatment } \\
\text { techniques, cost considerations, expert judgment, } \\
\text { and public comments. }\end{array}$ & $\begin{array}{l}\text { U.S. Environmental } \\
\text { Protection Agency, } \\
2003 \text { and } 2006 .\end{array}$ \\
\hline
\end{tabular}


Appendix 5. Comparison of volatile organic compounds (VOCs) detected in the source water during phase 1 of the Source WaterQuality Assessment (SWQA) with VOCs detected in other local and regional studies.

[ULUS, urban land-use study; MAS, major aquifer study; VOC, volatile organic compound; n, number of samples; ND, not detected; --, not analyzed, reported, and (or) not able to calculate a ranking because compound was not detected]

\begin{tabular}{|c|c|c|c|c|c|c|c|c|}
\hline \multirow{3}{*}{$\begin{array}{l}\text { Regulated (R) or } \\
\text { unregulated (U) } \\
\text { compound }\end{array}$} & \multicolumn{8}{|c|}{ Study identifier (from table 2) } \\
\hline & \multicolumn{2}{|c|}{$\begin{array}{c}\text { A } \\
\text { (SWOA) }\end{array}$} & \multicolumn{2}{|c|}{$\begin{array}{c}\text { B } \\
\text { (ULUS) }\end{array}$} & \multicolumn{2}{|c|}{$\begin{array}{c}\text { C } \\
\text { (MAS) }\end{array}$} & \multicolumn{2}{|c|}{$\begin{array}{c}\text { D } \\
\text { (Bradner and others, 2005) }\end{array}$} \\
\hline & $\begin{array}{c}\text { Percent } \\
\text { detection } \\
n=30\end{array}$ & $\begin{array}{l}\text { VOC } \\
\text { Rank }\end{array}$ & $\begin{array}{c}\begin{array}{c}\text { Percent } \\
\text { detection } \\
n=34\end{array}\end{array}$ & $\begin{array}{l}\text { VOC } \\
\text { Rank }\end{array}$ & $\begin{array}{c}\begin{array}{c}\text { Percent } \\
\text { detection } \\
n=60\end{array}\end{array}$ & $\begin{array}{l}\text { VOC } \\
\text { Rank }\end{array}$ & $\begin{array}{c}\begin{array}{c}\text { Percent } \\
\text { detection } \\
\mathrm{n}=30\end{array}\end{array}$ & $\begin{array}{l}\text { VOC } \\
\text { Rank }\end{array}$ \\
\hline Chloroform (R) & 43 & 1 & 12 & 3 & 35 & 1 & 27 & 4 \\
\hline Carbon disulfide (U) & 17 & 2 & 35 & 1 & 10 & 4 & 3.3 & 19 \\
\hline Perchloroethene (R) (PCE) & 13 & 3 & 12 & 3 & 1.7 & 5 & 23 & 5 \\
\hline Bromodichloromethane (R) & 10 & 4 & 3 & 7 & 1.7 & 5 & 23 & 5 \\
\hline 1,2,4-Trimethylbenzene (U) & 10 & 4 & ND & -- & ND & -- & ND & -- \\
\hline Bromoform (R) & 6.7 & 6 & ND & -- & ND & -- & 10 & 11 \\
\hline 1,1-Dichloroethane (U) & 3.3 & 7 & ND & -- & 1.7 & 5 & 13 & 10 \\
\hline cis-1,2-Dichloroethene (R) & 3.3 & 7 & 2.9 & 7 & 1.7 & 5 & 40 & 1 \\
\hline $\begin{array}{l}\text { Methyl tert-butyl ether (U) } \\
\text { (MTBE) }\end{array}$ & 3.3 & 7 & 2.9 & 7 & 1.7 & 5 & 30 & 2 \\
\hline Trichlorofluoromethane (U) & 3.3 & 7 & ND & -- & ND & -- & ND & -- \\
\hline Trichloroethene (R) & 3.3 & 7 & 2.9 & 8 & 1.7 & 5 & 20 & 7 \\
\hline Toluene (R) & ND & -- & 18 & 2 & 25 & 2 & 17 & 9 \\
\hline Isopropylbenzene (U) & ND & -- & 5.9 & 5 & ND & -- & ND & -- \\
\hline Tetrahydrofuran (U) & ND & -- & 5.9 & 5 & ND & -- & ND & -- \\
\hline Dichloromethane (R) & ND & -- & 3.1 & 7 & 1.7 & 5 & ND & -- \\
\hline Bromochloromethane (U) & ND & -- & 2.9 & 8 & ND & -- & ND & -- \\
\hline Dichlorodifluoromethane (U) & ND & -- & 2.9 & 8 & 1.7 & 5 & 6.7 & 13 \\
\hline 1,2-Dichloropropane (U) & ND & -- & 2.9 & 8 & 23 & 3 & ND & -- \\
\hline 1-Methyl-4-isopropylbenzene (U) & ND & -- & 2.9 & 8 & ND & -- & ND & -- \\
\hline 1,1-Dichloroethene (R) & ND & -- & ND & -- & 1.7 & 5 & ND & -- \\
\hline Ethylbenzene (R) & ND & -- & ND & -- & 1.7 & 5 & ND & -- \\
\hline Styrene (R) & ND & -- & ND & -- & 1.7 & 5 & ND & -- \\
\hline 1,4-Dichlorobenzene (R) & ND & -- & ND & -- & ND & -- & 30 & 2 \\
\hline Chlorobenzene (R) & ND & -- & ND & -- & ND & -- & 20 & 7 \\
\hline 1,2-Dichlrobenzene (R) & ND & -- & ND & -- & ND & -- & 10 & 11 \\
\hline Benzene (R) & ND & -- & ND & -- & ND & -- & 6.7 & 13 \\
\hline Dibromochloromethane (R) & ND & -- & ND & -- & ND & -- & 6.7 & 13 \\
\hline trans-1,2-Dichloroethene $(\mathrm{R})$ & ND & -- & ND & -- & ND & -- & 6.7 & 13 \\
\hline $\begin{array}{l}\text { 1,1,2-Trichloro-1,2,2- } \\
\text { trifluoroethane (R) }\end{array}$ & ND & -- & ND & -- & ND & -- & 6.7 & 13 \\
\hline Vinyl chloride (R) & ND & -- & ND & -- & ND & -- & 6.7 & 13 \\
\hline Chloromethane (R) & ND & -- & ND & -- & ND & -- & 3.3 & 19 \\
\hline
\end{tabular}


Appendix 6. Comparison of pesticides detected in the source water during phase 1 of the Source Water-Quality Assessment (SWQA) with pesticides detected in other local and regional studies.

[ULUS, urban land-use study; MAS, major aquifer survey; n, number of samples; ND, not detected; --, not analyzed, reported, and (or) not able to calculate a ranking because compound was not detected; $p, p$ '-DDE, dichlorodiphenyldichloroethylene]

\begin{tabular}{|c|c|c|c|c|c|c|c|c|}
\hline \multirow{2}{*}{$\begin{array}{l}\text { Regulated }(R) \text { or } \\
\text { unregulated }(U) \\
\text { compound }\end{array}$} & \multicolumn{8}{|c|}{ Study identifier (from table 2) } \\
\hline & \multicolumn{2}{|c|}{$\begin{array}{c}\text { A } \\
\text { (SWQA) }\end{array}$} & \multicolumn{2}{|c|}{$\begin{array}{c}\text { B } \\
\text { (ULUS) }\end{array}$} & \multicolumn{2}{|c|}{$\begin{array}{c}\text { C } \\
\text { (MAS) }\end{array}$} & \multicolumn{2}{|c|}{$\begin{array}{c}\text { D } \\
\text { (Bradner and others, 2005) }\end{array}$} \\
\hline Atrazine $(\mathrm{R})$ & 23 & 2 & 3 & 6 & 1.7 & 2 & 73 & 2 \\
\hline 2-Hydroxyatrazine (U) & 23 & 2 & 3 & 6 & ND & -- & ND & -- \\
\hline Bentazon $(U)$ & 20 & 4 & 15 & 1 & ND & -- & -- & -- \\
\hline Prometon (U) & 17 & 5 & 3 & 6 & 1.7 & 2 & 47 & 5 \\
\hline Simazine (R) & 13 & 6 & ND & -- & 3.3 & 1 & 27 & 7 \\
\hline Tebuthiuron (U) & 6.7 & 7 & 12 & 2 & 1.7 & 2 & 77 & 1 \\
\hline Bromacil (U) & 3.3 & 10 & 9 & 3 & ND & -- & -- & -- \\
\hline 3,4-Dichloroaniline (U) & 3.3 & 10 & ND & -- & ND & -- & ND & -- \\
\hline Fonofos, oxygen analyge (U) & 3.3 & 10 & ND & -- & ND & -- & ND & -- \\
\hline Hexazinone (U) & ND & -- & 6 & 4 & ND & -- & ND & -- \\
\hline Imazaquin (U) & ND & -- & 6 & 4 & ND & -- & ND & -- \\
\hline 2-Amino- $n$-isopropylbenzamide & ND & -- & 3 & 6 & ND & -- & ND & -- \\
\hline Chlordiamino-s-triazine (U) & ND & -- & 3 & 6 & ND & -- & ND & -- \\
\hline $2,4-\mathrm{DB}(\mathrm{U})$ & ND & -- & 3 & 6 & ND & -- & ND & -- \\
\hline Propoxur (U) & ND & -- & 3 & 6 & ND & -- & ND & -- \\
\hline Diazinon (U) & ND & -- & ND & -- & 3.3 & 1 & -- & -- \\
\hline Diuron $(\mathrm{U})$ & ND & -- & ND & -- & ND & -- & 53 & 4 \\
\hline Metolachlor (U) & ND & -- & ND & -- & ND & -- & 27 & 7 \\
\hline 2,6-Diethylaniline (U) & ND & -- & ND & -- & ND & -- & 13 & 9 \\
\hline Butylate (U) & ND & -- & ND & -- & ND & -- & 6.7 & 10 \\
\hline$p, p^{\prime}-\mathrm{DDE}(\mathrm{U})$ & -- & -- & -- & -- & -- & -- & 6.7 & 10 \\
\hline Dieldrin (U) & ND & -- & ND & -- & ND & -- & 6.7 & 10 \\
\hline EPTC $(U)$ & ND & -- & ND & -- & ND & -- & 6.7 & 10 \\
\hline Norflurazon (U) & ND & -- & ND & -- & ND & -- & 3.3 & 14 \\
\hline
\end{tabular}


Appendix 7. Comparison of other anthropogenic organic compounds (OAOCs) detected in the source water during phase 1 of the Source Water-Quality Assessment (SWOA) with OAOCs detected in a local study.

[n, number of samples; ND, not detected; --, not analyzed, reported, and (or) not able to calculate a ranking because compound was not detected]

\begin{tabular}{|c|c|c|c|c|}
\hline \multirow{3}{*}{$\begin{array}{l}\text { Compound Name (all are unregulated } \\
\text { compounds) }\end{array}$} & \multicolumn{4}{|c|}{ Study Identifier (from table 2) } \\
\hline & \multicolumn{2}{|c|}{$\begin{array}{c}A \\
\text { (SWOA) }\end{array}$} & \multicolumn{2}{|c|}{$\begin{array}{c}\text { E } \\
\text { (Phelps, 2004) } \\
\end{array}$} \\
\hline & $\begin{array}{l}\text { Percent detection } \\
\quad \mathrm{n}=30\end{array}$ & $\begin{array}{l}\text { OAOC } \\
\text { rank }\end{array}$ & $\begin{array}{l}\text { Percent detection } \\
\quad \mathrm{n}=38\end{array}$ & $\begin{array}{l}\text { OAOC } \\
\text { rank }\end{array}$ \\
\hline N,N,-diethyl-meta-toluamide (DEET) & 17 & 1 & 79 & 1 \\
\hline Cholesterol & 6.7 & 2 & 11 & 4 \\
\hline 3-beta-Coprostanol & 6.7 & 2 & 2.6 & 14 \\
\hline$p$-Cresol & 3.3 & 4 & 7.9 & 8 \\
\hline Indole & 3.3 & 4 & 2.6 & 14 \\
\hline 4-Octylphenol diethoxylate & 3.3 & 4 & 2.6 & 14 \\
\hline beta-Sitosterol & 3.3 & 4 & 2.6 & 14 \\
\hline beta-Stigmastanol & 3.3 & 4 & ND & -- \\
\hline Bisphenol-A & ND & -- & 29 & 2 \\
\hline Triclosan & ND & -- & 16 & 3 \\
\hline Isophorone & ND & -- & 11 & 4 \\
\hline 4-Nonylphenol (total) & ND & -- & 11 & 4 \\
\hline Tri(2-chloroethyl)phosphate (TCEP) & ND & -- & 11 & 4 \\
\hline Caffeine & ND & -- & 7.9 & 8 \\
\hline Benzophenone & ND & -- & 5.3 & 10 \\
\hline Diethoxynonylphenone & ND & -- & 5.3 & 10 \\
\hline 2-Methylnaphthalene & ND & -- & 5.3 & 10 \\
\hline Tributyl phosphate & ND & -- & 5.3 & 10 \\
\hline
\end{tabular}


Appendix 8. Comparison between source and associated finished water for anthropogenic organic compounds detected during phase 2 of the Source Water-Quality Assessment.

[Shaded cells indicate blended water. $\mu \mathrm{g} / \mathrm{L}$, micrograms per liter; E, estimated value; ND, not detected]

\begin{tabular}{|c|c|c|c|}
\hline Well identifier & $\begin{array}{c}\text { Detected anthropogenic } \\
\text { organic compound } \\
\text { (regulated (R) or unregulated (U)) }\end{array}$ & $\begin{array}{c}\text { Source water } \\
(\mu \mathrm{g} / \mathrm{L})\end{array}$ & $\begin{array}{c}\text { Finished water, } \\
\text { nonblended or } \\
\text { blended } \\
(\mu \mathrm{g} / \mathrm{L})\end{array}$ \\
\hline \multicolumn{4}{|c|}{ Volatile organic compounds } \\
\hline 22 & Acetone (U) & 68.4 & ND \\
\hline 20 & Bromoform $(\mathrm{R})$ & ND & 0.482 \\
\hline 23 & Bromoform $(\mathrm{R})$ & ND & .546 \\
\hline 29 & Bromoform $(\mathrm{R})$ & ND & E.127 \\
\hline 2 & Bromoform $(\mathrm{R})$ & ND & .18 \\
\hline 10 & Bromoform (R) & ND & E.02 \\
\hline 20 & Bromodichloromethane (R) & ND & 1.78 \\
\hline 21 & Bromodichloromethane (R) & ND & .571 \\
\hline 22 & Bromodichloromethane (R) & ND & E.053 \\
\hline 23 & Bromodichloromethane (R) & ND & 2.94 \\
\hline 29 & Bromodichloromethane (R) & ND & 3.13 \\
\hline 2 & Bromodichloromethane (R) & ND & 7.48 \\
\hline 11 & Bromodichloromethane (R) & ND & 3.19 \\
\hline 15 & Bromodichloromethane (R) & ND & .74 \\
\hline 18 & Chloroform (R) & .948 & 1.35 \\
\hline 20 & Chloroform (R) & .269 & 1.23 \\
\hline 21 & Chloroform (R) & E.051 & .453 \\
\hline 22 & Chloroform (R) & .304 & .356 \\
\hline 23 & Chloroform (R) & .504 & 3.18 \\
\hline 29 & Chloroform (R) & E.035 & 3.64 \\
\hline 2 & Chloroform (R) & ND & 36.3 \\
\hline 11 & Chloroform (R) & ND & 24.6 \\
\hline 15 & Chloroform (R) & .151 & .82 \\
\hline 17 & Chloroform (R) & .36 & 1.43 \\
\hline 29 & Chloromethane (U) & ND & E.116 \\
\hline
\end{tabular}


Appendix 8. Comparison between source and associated finished water for anthropogenic organic compounds detected during phase 2 of the Source Water-Quality Assessment.-Continued

[Shaded cells indicate blended water. $\mu \mathrm{g} / \mathrm{L}$, micrograms per liter; E, estimated value; ND, not detected]

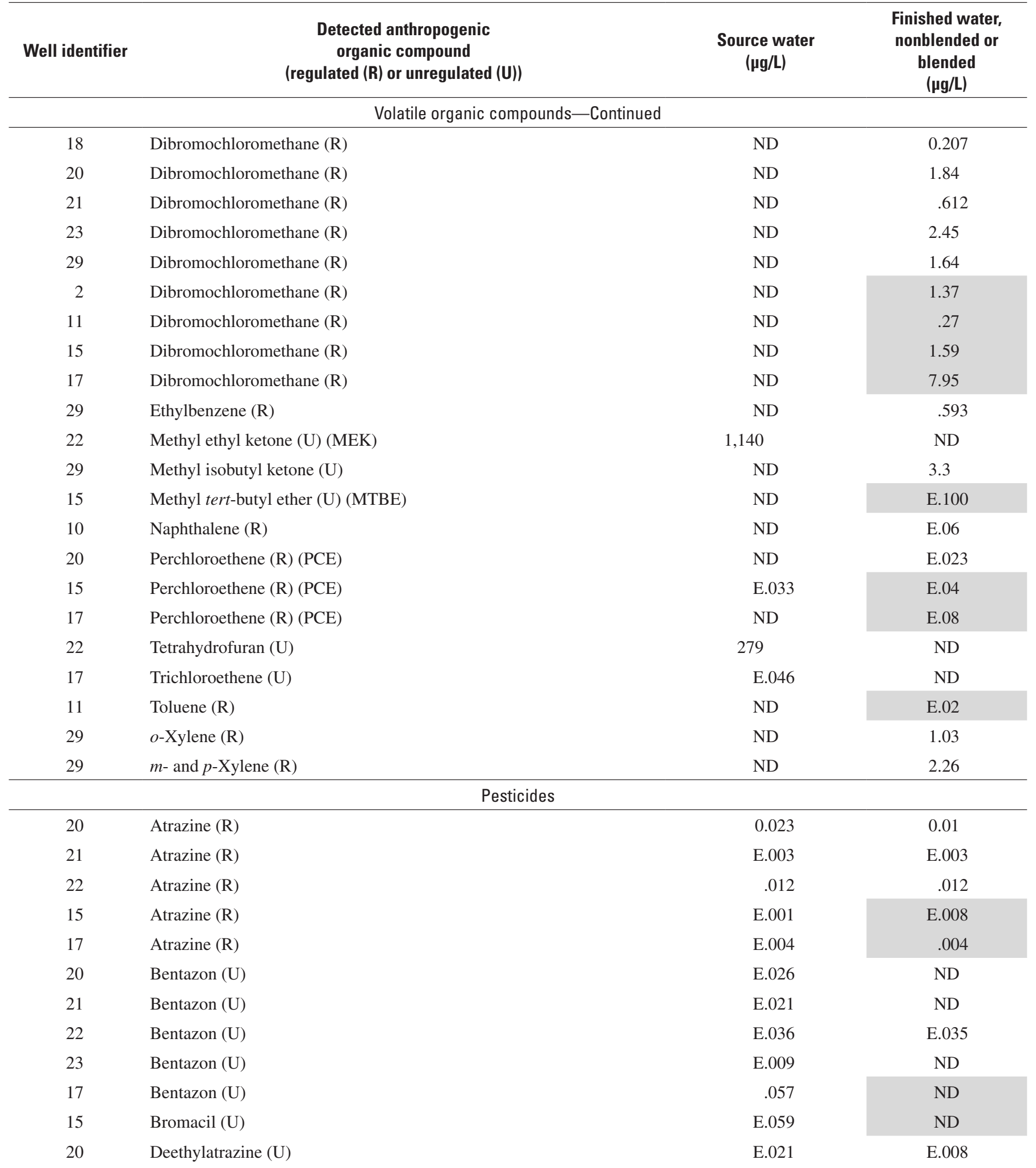


Appendix 8. Comparison between source and associated finished water for anthropogenic organic compounds detected during phase 2 of the Source Water-Quality Assessment.-Continued

[Shaded cells indicate blended water. $\mu \mathrm{g} / \mathrm{L}$, micrograms per liter; E, estimated value; ND, not detected]

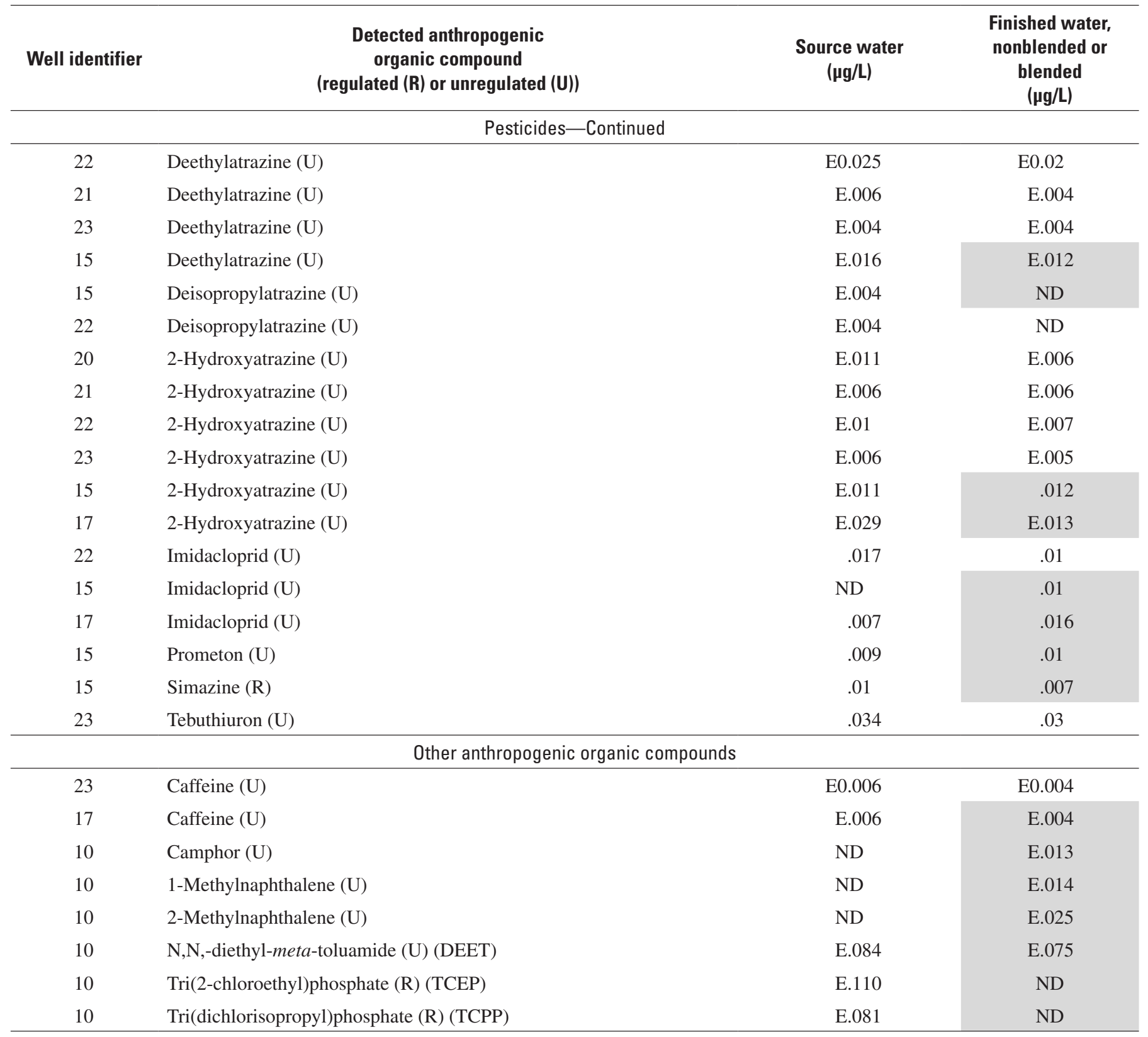


Prepared by the USGS Publishing Network, Helena Publishing Service Center.

For more information concerning the research in this report, contact: National Water-Quality Assessment Program,

The University Center for Business

10500 University Center Drive, Suite 215

Tampa, Florida 33612-6427

Information regarding the National Water-Quality Assessment Program is available at $h$ ttp://fl.water.usgs.gov/nawqa/ 
